\title{
Basal middle Miocene Listriodontinae (Suidae, Artiodactyla) from Madrid, Spain
}

\author{
Martin PICKFORD ${ }^{1 *}$ \& Jorge MORALES
}

\author{
${ }^{1}$ Sorbonne Universités - CR2P, MNHN, CNRS, UPMC - Paris VI, 8, rue Buffon, 75005, Paris, France; martin.pickford@mnhn.fr \\ ${ }^{2}$ Departamento de Paleobiología, Museo Nacional de Ciencias Naturales-CSIC, c/ José Gutiérrez Abascal 2, 28006, Madrid, \\ Spain; monm166@mncn.csic.es \\ * Corresponding author
}

Pickford, M. \& Morales, J. 2016. Basal middle Miocene Listriodontinae (Suidae, Artiodactyla) from Madrid, Spain. [Listriodontinae (Suidae, Artiodactyla) de la base del Mioceno medio de Madrid, España]. Spanish Journal of Palaeontology, 31 (2), 369-406.

\begin{abstract}
Excavations in basal middle Miocene deposits in the Madrid Basin (Old Mahou Brewery, Los Nogales, La Hidroeléctrica, Guadarrama I, Barajas) have yielded interesting assemblages of fossils, among which the listriodont suid Listriodon retamaensis Pickford \& Morales, 2003, is well represented. Much of the material is juvenile, and several of the permanent teeth are unworn, permitting detailed observations to be made of the fine structures of the crowns, which was not possible with the original hypodigm of the species from Retama due to the heavy wear on most of the teeth in that sample. Refinement of the definition of the species is thus possible. Los Nogales also yielded two teeth of the small tetraconodont suid Retroporcus complutensis.
\end{abstract}

Keywords: Madrid, Spain, middle Miocene, Listriodontinae, Suidae, dentition, biochronology

\section{RESUMEN}

Las excavaciones en los depósitos del Mioceno medio basal en la Cuenca de Madrid (Antigua Fábrica de Mahou, Los Nogales, La Hidroeléctrica, Guadarrama I, Barajas) han aportado una interesante asociación de fósiles, entre los que la especie Listriodon retamaensis Pickford \& Morales, 2003 está muy bien representada. Buena parte del material corresponde a individuos juveniles y algunos de los dientes permanentes están intactos, lo que permite hacer observaciones de detalle de las estructuras de la corona. Esto no se pudo hacer con el material original de la especie, procedente del yacimiento de Retama, ya que la inmensa mayoría de los dientes estaban intensamente desgastado. Estas observaciones han permitido refinar la definición de la especie. En el yacimiento de Los Nogales también se han encontrado dos dientes pertenecientes a un pequeño tetraconodóntido, Retroporcus complutensis.

Palabras clave: Madrid, España, Mioceno medio, Listriodontinae, Suidae, dentición, biocronología 


\section{INTRODUCTION}

Building activity at the disaffected Mahou Brewery exposed richly fossiliferous deposits of middle Miocene age. Rescue excavations at this site as well as others in the Madrid Basin (Los Nogales, La Hidroeléctrica, Guadarrama I, and Barajas) yielded many fossils belonging to the poorly known small listriodont suid, Listriodon retamaensis Pickford \& Morales, 2003, and two teeth of the small tetraconodont Retroporcus complutensis Pickford \& Laurent, 2014.

Previously described samples of Listriodon retamaensis consisted of specimens with heavily worn teeth meaning that most details of crown morphology had been removed by wear, leaving the small dimensions as the main criterion for defining the species. Many of the permanent teeth from Mahou are unworn, revealing fine details of the morphology of the cusps. As a result, the Mahou sample throws light on the transition from a bunodont suid grundplan towards the lophodont morphology exhibited by derived listriodonts such as Listriodon splendens. In addition, there are many juveniles in the Mahou assemblage, so a more complete description of the deciduous dentition of an early listriodont species can be presented for the first time.

The fossils described in this paper are among the earliest listriodonts and tetraconodonts known, and they indicate descent from a Hyotherium-like ancestral stock.

\section{GEOLOGICAL AND BIOCHRONOLOGICAL BACKGROUND}

\subsection{Data on the fossil localities (Figs 1-2)}

Hidroeléctrica was discovered in 1921 during the excavation of ditches close to the river Manzanares (Hernández-Pacheco, 1921). During palaeontological control of road works around Madrid (Calle M-30) in 2006, the same fossil levels were encountered. In 2008 excavations continued nearby, prior to the construction of the Hotel Paseo Virgen del Puerto, which currently occupies the area. The fossils occur in compact grey marly limestone ("calizas margosas grises") (Peñuela Facies).

Guadarrama 1 was discovered in 1991 during palaeontological surveys related to preparation of the geological map of Madrid (1:50.000). It is located close to the bank of the Guadarrama River in detritic sediments comprising green micaceous sands. The only fossil found was the mandible described in this paper (Morales et al., 2000).

Los Nogales was discovered in 2003 during palaeontological control of the construction of buildings.
It is located close to the bank of the River Manzanares in compact brown and green clayey sediments with abundant manganese staining (associated with the Peñuelas Facies) (Herráez et al., 2006).

Barajas 17 was found in 2003 during palaeontological control of the construction of new landing strips at Barajas Airport. The fossils occur in detritic horizons, comprising mainly medium-grained arkosic sands. Nearby, sites were cited in Morales et al. (2000).

Mahou was found in 2013 during palaeontological control of building activity at the former Mahou Brewery. It is a short distance from the locality of La Hidroeléctrica. The fossils occur in pale green micaceous sand.

Fossil vertebrates found in these sites are compiled in Table 1.

\section{MATERIAL AND METHODS}

The fossils described herein are housed at the Museo Nacional de Ciencias Naturales, Madrid, Spain, where they are curated under the prefix "MNCN FMH'14" (Mahou) and "MNCN Los Nogales"; "HOT-SI" (La Hidroeléctrica), "BAR" (abbreviation of Barajas in the field catalogue).

Images were captured with a Sony Cybershot, 18.2 megapixel camera and treated with Photoshop Elements 3 to remove unwanted background and to optimise contrast. Scales were added manually.

Measurements of teeth were made with sliding calipers to the nearest $0.1 \mathrm{~mm}$. Cusp nomenclature is based on the tribosphenic system of Osborn (1907), with the grooves (Fürchen) numbered according to the scheme of Hünermann (1968) and Pickford (1988).

Dental nomenclature (Fig. 3) follows the schemes of Hünermann (1968), Pickford (1988), and Van der Made (1996). In this paper, lower case letters (c - canine, d deciduous molar, $\mathrm{i}$ - incisor, $\mathrm{p}-$ premolar, $\mathrm{m}-$ molar) signify lower teeth, whereas upper case letters (C, D, I, $\mathrm{P}, \mathrm{M})$ signify upper teeth. The meristic position is given beneath the forward slash for lower teeth and above the forward slash for upper teeth (i.e. the forward slash denotes the occlusal surface). The letters " $m$ " or " $\mathrm{f}$ " associated with the canine denote male and female, respectively. Thus $\mathrm{c} / \mathrm{m}$ signifies a lower male canine; D4/ signifies the upper $4^{\text {th }}$ deciduous molar; $\mathrm{p} / 3$ signifies the lower third premolar; M1/ the first upper molar, and so on. This system of presentation, even though somewhat redundant (because lower case or upper case letters denote the lower or upper tooth row, as does the forward slash relative to the meristic position), alerts the author and the reader about typographical errors (for example if a "c" is accidentally typed " $C$ ") because the meristic position relative to the forward slash provides sounder evidence about the tooth row from which the specimen came. 
Table 1. Faunal lists of sites in the Madrid Basin that have yielded remains of Listriodon retamaensis.

\begin{tabular}{|c|c|c|c|}
\hline LA HIDROEL & $\begin{array}{c}\text { MAHOU } \\
\text { (preliminary identifications) }\end{array}$ & $\begin{array}{l}\text { LOS NOGALES } \\
\text { (revised from Herráez et al., 2006) }\end{array}$ & $\begin{array}{c}\text { BARAJAS } \mathbf{1 7} \\
\text { (preliminary identifications) }\end{array}$ \\
\hline $\begin{array}{l}\text { CARNIVORA } \\
\text { Amphicyon major } \\
\text { Proputorius sp. } \\
\text { Mustelidae indet. } \\
\text { ARTIODACTYLA } \\
\text { Cainotherium } \\
\text { miocaenicum } \\
\text { Listriodon retamaensis } \\
\text { Micromeryx flourensianus } \\
\text { Amphitragulus sp. } \\
\text { Procervulus dichotomus } \\
\text { Triceromeryx pachecoi } \\
\text { Bovidae indet. } \\
\text { PERISSODACTYLA } \\
\text { Hispanotherium } \\
\text { matritense } \\
\text { Hoploaceratherium } \\
\text { tetradactylum } \\
\text { Anchitherium alberdiae } \\
\text { PROBOSCIDEA } \\
\text { Gomphotherium } \\
\text { angustidens } \\
\text { Zygolophodon turiciensis }\end{array}$ & $\begin{array}{l}\text { RODENTIA } \\
\text { Heteroxerus sp. } \\
\text { Democricetodon sp. } \\
\text { Megacricetodon sp. } \\
\text { Armantomys sp. } \\
\text { CARNIVORA } \\
\text { Amphicyonidae indet. } \\
\text { Mustelidae indet. } \\
\text { Protictitherium sp. } \\
\text { Felidae indet. } \\
\text { ARTIODACTYLA } \\
\text { Cainotherium sp. } \\
\text { Listriodon retamaensis } \\
\text { Procervulus dichotomus } \\
\text { Triceromeryx pachecoi } \\
\text { Bovidae indet. } \\
\text { PERISSODACTYLA } \\
\text { Hispanotherium } \\
\text { matritense } \\
\text { Anchitherium sp. } \\
\text { PROBOSCIDEA } \\
\text { Gomphotherium } \\
\text { angustidens }\end{array}$ & $\begin{array}{l}\text { RODENTIA } \\
\text { Democricetodon jordensi } \\
\text { Megacricetodon } \\
\text { collongensis } \\
\text { Microdyromys koenigswaldi } \\
\text { Armantomys aragonensis } \\
\text { Armantomys cf. jasperi } \\
\text { Gliridae indet. } \\
\text { Heteroxerus rubricati } \\
\text { LAGOMORPHA } \\
\text { Lagopsis penai } \\
\text { CARNIVORA } \\
\text { Amphicyon sp. } \\
\text { Mustelidae indet. } \\
\text { Magerictis imperialensis } \\
\text { Felidae indet. } \\
\text { ARTIODACTYLA } \\
\text { Cainotherium miocaenicum } \\
\text { Listriodon retamaensis } \\
\text { Retroporcus complutensis } \\
\text { Procervulus dichotomus } \\
\text { Priceromeryx sp. } \\
\text { Bovidae indet. } \\
\text { GomisSODACTYLA } \\
\text { Hispanotherium matritense } \\
\text { Anchitherium alberdiae } \\
\text { Anchitherium sp. } \\
\text { Gotherium angustidens }\end{array}$ & $\begin{array}{l}\text { CARNIVORA } \\
\text { Amphicyon sp. } \\
\text { PERISSODACTYLA } \\
\text { Magerictis } \\
\text { imperialensis } \\
\text { Anchitherium sp. } \\
\text { Hispanotherium } \\
\text { matritensis } \\
\text { ARTIODACTYLA } \\
\text { Listriodon retamaensis } \\
\text { Cervidae indet. } \\
\text { Bovidae indet. } \\
\text { Palaeomerycidae indet. } \\
\text { PROBOSCIDEA } \\
\text { Gomphotherium } \\
\text { angustidens }\end{array}$ \\
\hline $\begin{array}{l}\text { Giant tortoises and a variety } \\
\text { of birds are associated with } \\
\text { these mammals. } \\
\text { The locality correlates to Dc } \\
\text { MN5 }\end{array}$ & $\begin{array}{l}\text { Giant tortoises and a variety } \\
\text { of birds are associated with } \\
\text { these mammals. } \\
\text { The locality correlates to } \\
\text { Dc MN5 }\end{array}$ & $\begin{array}{l}\text { Giant tortoises and a variety of } \\
\text { birds are associated with these } \\
\text { mammals. } \\
\text { The locality correlates to Dc } \\
\text { MN5 }\end{array}$ & $\begin{array}{l}\text { Giant tortoises and a variety } \\
\text { of birds are associated with } \\
\text { these mammals. } \\
\text { The locality correlates to } \\
\text { Dd MN5 }\end{array}$ \\
\hline
\end{tabular}

\section{SYSTEMATIC PALAEONTOLOGY}

Family Suidae Gray, 1821

Subfamily Listriodontinae Simpson, 1945

Genus Listriodon von Meyer, 1846

Listriodon retamaensis Pickford \& Morales, 2003

Holotype. RET 574, snout of a female individual with left $\mathrm{I} 3 /$, left and right canine roots, left and right
P1/-P3/ (left P3/ broken), housed at the Museo Nacional de Ciencias Naturales, $(\mathrm{MNCN})$ Madrid.

Paratypes. RET 740, right I1/; RET 348, left maxilla with $\mathrm{P} 3 /-\mathrm{M} 3 /$ and right maxilla with M2/-M3/; RET 832, upper male canine, right $\mathrm{p} / 4$; RET 2 , left mandible fragment with $\mathrm{m} / 1-\mathrm{m} / 3$ (occludes perfectly with RET 348); RET 338, right mandible fragment with broken $\mathrm{m} / 3$. Housed at the Museo Nacional de Ciencias Naturales, Madrid. 


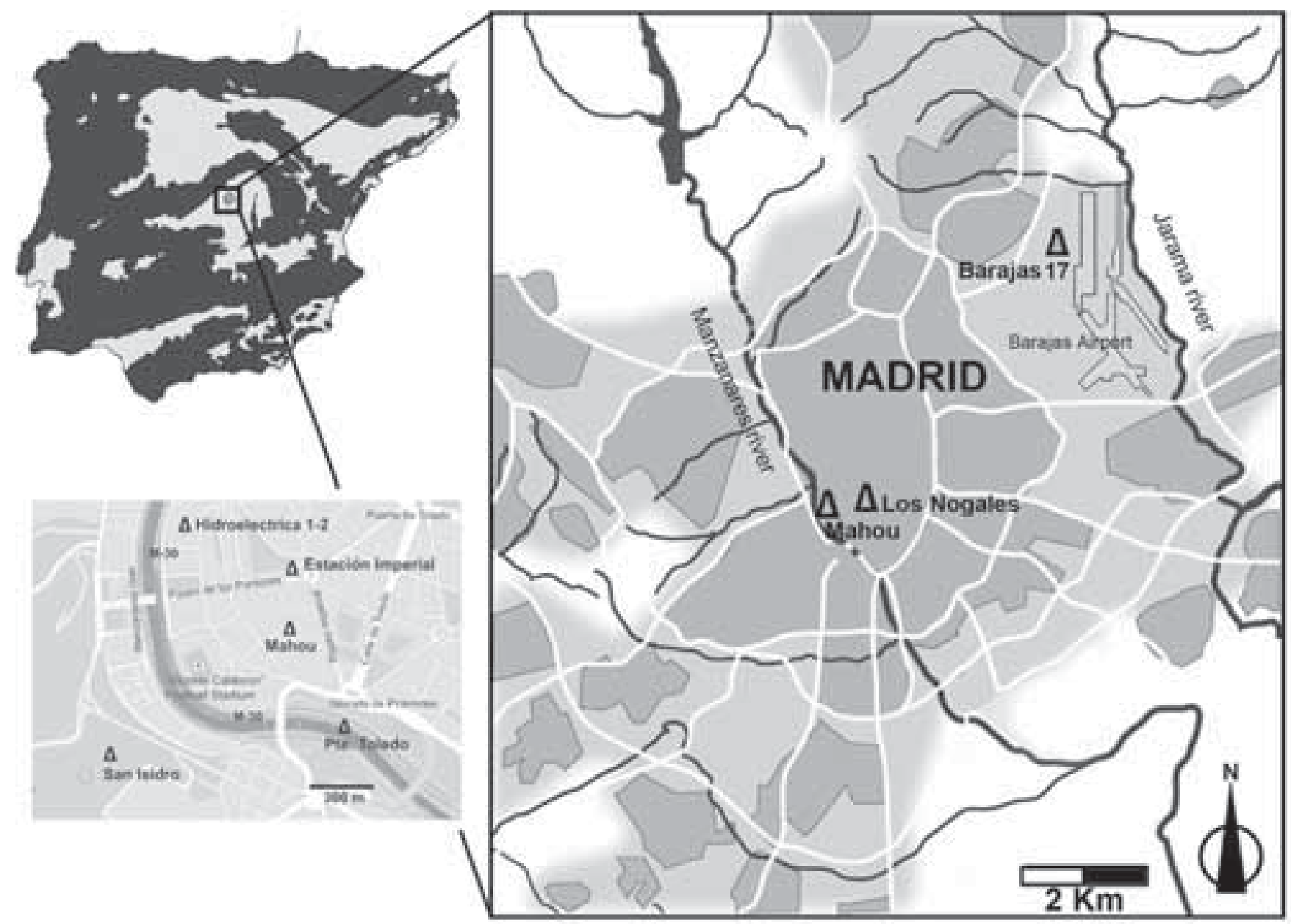

Figure 1. Geographic location of Miocene localities that yielded the new samples of suids. Los Nogales and Mahou are close to the Manzanares River in the old part of the City of Madrid, not far from the classic localities found in the middle of the 19th Cenury (San Isidro and Puente de Toledo). Barajas 17 is located within the boundary of Barajas Airport.

Material from Mahou, Madrid (Spain). This material is illustrated in Figures 3-17. All specimens are labelled with the prefix "MNCN FMH'14": 433 - juvenile right mandible containing $\mathrm{d} / 2-\mathrm{m} / 2 ; 690$ - left M1/; 1467 - right male lower canine; 1617 - left M1/; 1618 - left D4/; 1905, right d/4-m/1; 2059 - juvenile left mandible with $\mathrm{d} / 3-\mathrm{m} / 1$; 2085 - right D4/; 2135 - left D3/; 2095 - left mandible with $\mathrm{p} / 3-\mathrm{m} / 1 ; 2452$ - left mandible containing male canine and $\mathrm{p} / 2-\mathrm{m} / 3 ; 2715$ - right mandible fragment containing $\mathrm{m} / 1-\mathrm{m} / 3 ; 2818$ - right $\mathrm{p} / 3$ and $\mathrm{p} / 4 ; 2932$ - crushed juvenile snout containing right $\mathrm{DC} 1 /$, right alveolus for $\mathrm{P} 1 /$, left and right $\mathrm{D} 2 /-\mathrm{M} 2 /$ erupted and left and right $\mathrm{P} 2 /-\mathrm{P} 4 /$ and M3/ in crypt; 3096 - right mandible fragment containing d/3-d/4; 3202 - left maxilla containing D3/-M1/; 3247 right upper male canine; 3338 - left p/4;3348 - right M1/; 3351 - symphysis containing right male lower canine and alveoli of incisors and right $\mathrm{p} / 1 ; 3399-$ right $\mathrm{i} / 2 ; 3478-$ left mandible containing $\mathrm{m} / 1-\mathrm{m} / 3 ; 3492-$ left $\mathrm{d} / 2 ; 3559$ - juvenile mandible containing left and right $\mathrm{d} / 2-\mathrm{d} / 4$ and $\mathrm{m} / 1-\mathrm{m} / 2$, left and right $\mathrm{i} / 2$ and $\mathrm{m} / 3$ in crypt; 3569 - right
$\mathrm{P} 4 / ; 3570$ - right $\mathrm{P} 3 / ; 3615$ - left $\mathrm{P} 2 /$ and $\mathrm{P} 4 / ; 3617$ - left $\mathrm{P} 3 / ; 3623$ - left I1/; 3711 - left d/2; 3762 - right M2/; 3766 - right d/3; 3959 - right $\mathrm{P} 1 / ; 3989$ - left $\mathrm{P} 1 / ; 4009$ - right male lower canine; 4028 - broken and worn right $\mathrm{m} / 3 ; 4039$ - right D2/; 4075 - right male upper canine; 4081 - left M2/; 4163 - broken left m/3; 4195 - right M1/; 4236 - left M3/; 4421 - left d/4; 4890 - right M2/; 4147 - right $\mathrm{p} / 3$ and $\mathrm{p} / 4 ; 5138$ - mesial lophid of left $\mathrm{m} / 2$; 3247 - left talus; 4158 - left talus; 2793 - left unciform; 1922 - MC IV; 3943 - MT IV; 4213 - ectocuneiform; 2741 - right radius.

Material from Los Nogales, Madrid (Spain). The material is illustrated in Figures 18-23. Locality prefix is MNCM NG: 1001 - complete male mandible; 1002 - left I1/; 1003 - left maxilla fragment with P4/-M1/; 1004 right maxillary teeth $\mathrm{D} 4 /-\mathrm{M} 2 /$ and $\mathrm{P} 4 / ; 1005$ - left di/2; 1006 - right D4/ and M1/; 1007 - right male upper canine; 1008 - left male upper canine; 1009 - right male lower canine; 1010 - second phalanx. 


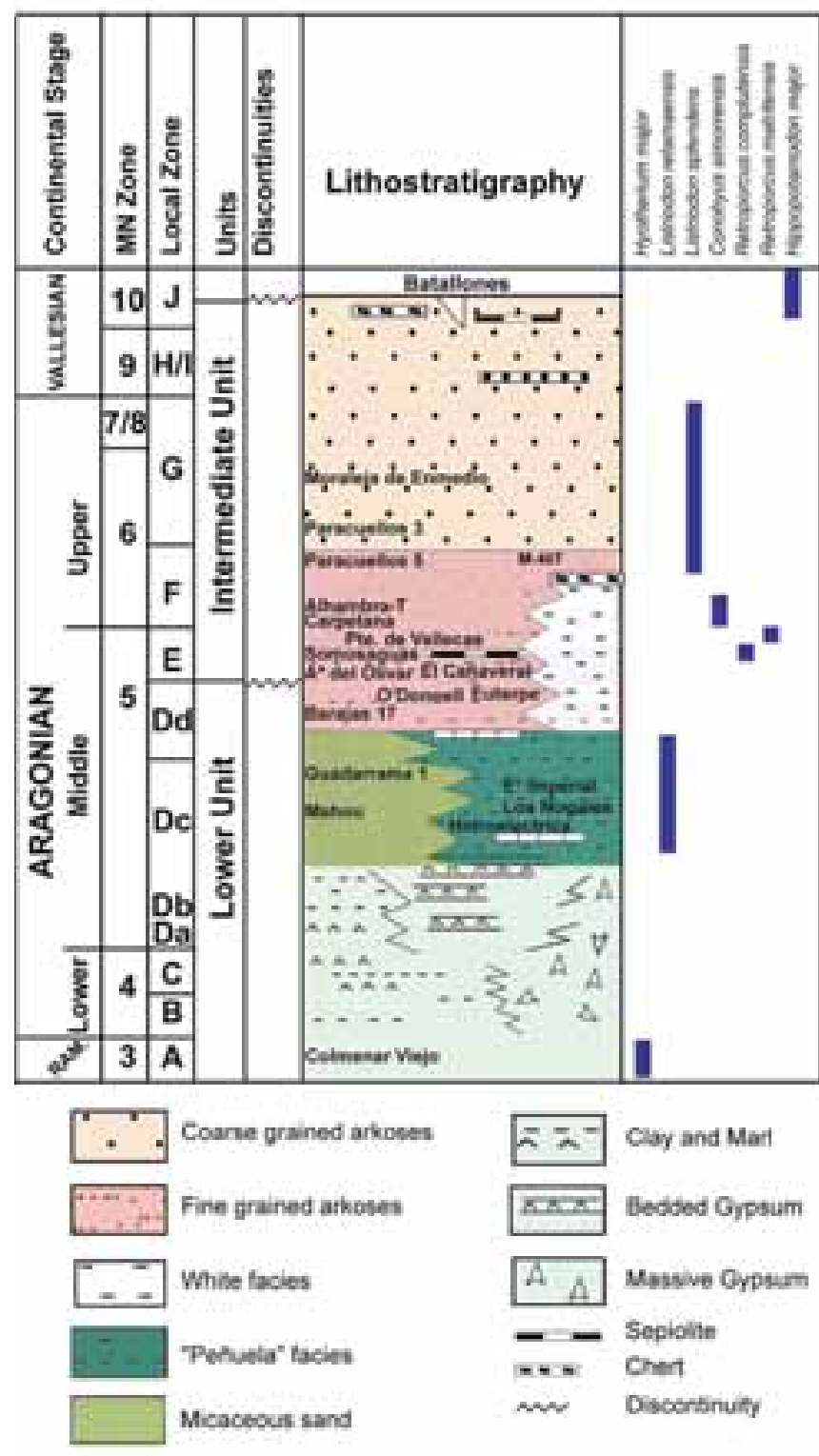

Figure 2. Biostratigraphy and lithostratigraphy of Miocene localities in the Madrid Basin, with the stratigraphic ranges of the diverse species of suids found therein. The lithostratigraphic scheme is modified from LópezMartínez et al. (1987), Calvo et al. (1993), Morales et al. (2000), and Peláez-Campomane et al. (2003). Local zonation is from Daams et al. (1999). MN zones are from Mein (1975), and Bruijn et al. (1992). RAM.: Ramblian.

Material from La Hidroeléctrica. The material is represented in Figures 24-27. HOT-SI-06 - left m/1; HOTSI-H-14 - right P4/; HOT-SI-H-14 - left P1/; HOT-SI-06 - left upper male canine; HOT-SI-072 - left upper male canine; HOT-SI-M5-160 - left P2/; HOT-SI-13T - left P4/; HOT-SI-F22 - right $\mathrm{d} / 4$ and $\mathrm{m} / 1$; HOT-SI-06/53 - right upper female canine; HOT-SI-06/53 - left D2/; HOTSI-06/53 - left i/1; HOT-SI-012 - left D3/.
Material from Barajas. The fossils are illustrated in Figures 28-35. MNCN-74600 (BAR 17/03 64 - symphysis of mandible with right lower male canine); MNCN-74601 (left juvenile mandible with $\mathrm{d} / 2-\mathrm{d} / 4$ ); MNCN-74602 (BAR 120 - left lower male canine); MNCN-74603 (BAR 17 - mandible with left $\mathrm{cm}, \mathrm{p} / 2-\mathrm{p} / 3, \mathrm{~m} / 2$ and $\mathrm{m} / 3$, right $\mathrm{p} / 3-\mathrm{m} / 3$ ); MNCN-74604 (BAR 17 - right mandible with $\mathrm{p} / 4-\mathrm{m} / 3$ ); MNCN-74605 (BAR 17/03 - right M1/); MNCN-74606 ( BAR 17/04 - left juvenile mandible with d/3-d/4); MNCN-74607 (BAR 62 - crushed mandible with left and right $\mathrm{i} / 1-\mathrm{i} / 2$, left $\mathrm{c} / \mathrm{m}$, left and right $\mathrm{p} / 2-\mathrm{m} / 3$ ); MNCN-74608 (BAR 17/12 - right i/3); MNCN-74609 (BAR 17/03 147 - left m/1); MNCN-74610 (BAR 17 left MC IV).

Material from Guadarrama I, Bohadilla del Monte. The specimen is illustrated in Figure 36. MNCN 72851 right mandible with $\mathrm{p} / 4-\mathrm{m} / 3$.

Type locality. Retama, Huete, Spain (MN4a).

Other localities. Mahou (Local Zone Dc = early MN5); Acacias (MN4b); Corcoles (MN4a); Estación Imperial (MN4b); La Hidroeléctrica (Local zone Dc = early MN5); Los Nogales (Local Zone Dc = early MN5); Barajas (Local zone Dd = late MN5); Guadarrama I (Local zone Dc = early MN5); Tejar Manzanares (MN5); Quinta de Lobeira (MN4a); Quinta da Silvéria (MN4b); Terrero (MN4a).

Age. Listriodon retamaensis is known from several basal middle Miocene localities in the Spanish Peninsula ranging in age from MN4a to late MN5 (ca. 17-15 Ma).

Original Diagnosis. Full complement of upper premolars, three lobed I1/ with a length-width index of about 177; bunolophodont dentition; metapodials short and robust (Pickford \& Morales, 2003).

Emended diagnosis. A small species of Listriodon with moderately elongated snout (diastemata between canine and premolar row shorter than in Eurolistriodon); bunolophodont cheek teeth, strong buccal cingula present in all upper molars; labial surface of I1/ shows a beaded cingular ridge on the mesial and distal parts; I1/ lengthwidth index ranges from ca. 177 to 221; apices of the anterior and posterior lobes of the I1/ are heavily beaded when unworn; apex of posterior lobe of I1/ has a shallow concave profile; upper molars have reduced anterior and posterior accessory cusps, but the median accessory cusp is well developed; lower molars have reduced anterior accessory cusps but prominent median and posterior accessory cusps; strong sexual dimorphism of the canines, males with hypselodont, scrofic lower canines, females with rooted, low crowned canines; upper male canines elongated, enlarged, hypselodont with prominent dorsal (i.e. lateral) gutter, flaring laterally and curving upwards, 

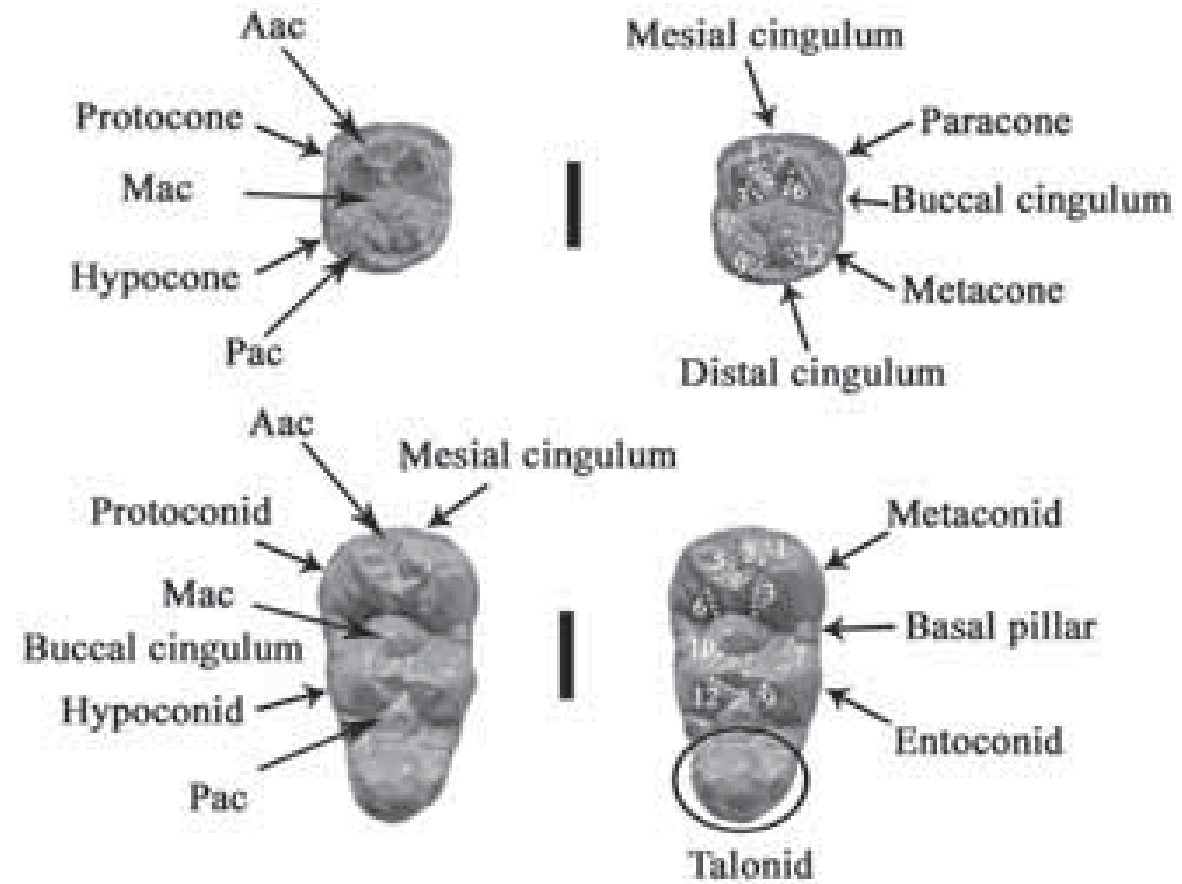

Figure 3. Dental nomenclature of left upper and lower molars of Listriodon retamaensis. The illustrated teeth are from Mahou, Madrid (Spain). Dotted lines denote the Fürchen, which are numbered according to the scheme of Hünermann (1968) but note that several of these grooves do not occur due to the advancing lophodonty expressed in this species. Aac: Anterior accessory cusplet; Mac: Median accessory cusplet; Pac: Posterior accessory cusplet. Stereo occlusal views. Scale bars $=10 \mathrm{~mm}$. female upper canine, lower crowned with closed root in which there is a buccal groove, tooth steeply implanted in jaw; Innenhügel (metaconid) of the $\mathrm{p} / 4$ as tall as the protoconid; full complement of upper and lower premolars ( $\mathrm{p} / 1$ sometimes shed in older individuals); the $\mathrm{P} 1 /$ and $\mathrm{p} / 1$ are immediately behind the canines, separated from the $\mathrm{P} 2 /$ and $\mathrm{p} / 2$ by a diastema ca $2-3 \mathrm{~cm}$ long; canine jugum broad in males.

Differential Diagnosis. Listriodon retamaensis differs from Listriodon latidens and other species of Listriodon (splendens, meidamon, lockharti, pentapotamiae) by its lesser dimensions. It differs from Listriodon lockharti, which has two lobes in the I1/ rather than three. In addition it differs from Listriodon splendens and L. meidamon by the much shorter mesio-distal dimension of I1/. It differs from Eurolistriodon adelli, which has an undivided, single lobed I1/, elongated metapodials, loss of first and second premolars, and a p/4 in which the Innenhügel is weak or absent and the buccal cusp in $\mathrm{P} 4 /$ which is single. It differs from Eurolistriodon tenarezensis, which has incomplete buccal cingula in the upper molars, and by the more diminutive dimensions of the cheek teeth. It is similar to Listriodon guptai in several morphometric features but differs from it by the less well-developed lophodonty in the upper and lower molars and by a more hook-shaped lingual outline of the upper central incisor crown.

\section{Description}

Skull. The juvenile snout, FMH'14 2932 (Fig. 4), is dorso-ventrally crushed and in the palate the right maxilla has over-ridden the left one to a small extent. The teeth are well preserved, although the milk teeth and M1/ are heavily worn. The deciduous upper canine is housed in a lateral extension of the maxilla. Ventrally this palatal extension is $17.5 \mathrm{~mm}$ broad measured from the lateral edge of the palatine groove, the same distance as that from the midline of the palate to the outer edge of the palatine groove. The canine flange thus effectively doubles the anterior diameter of the palate somewhat in the fashion of Eurolistriodon adelli Pickford \& Moyà-Solà (1995) and Eurolistriodon tenarezensis Orliac (2006) but being in a very juvenile state, it is difficult to judge how much bigger the canine flange would have become had the individual survived to maturity. As a result of the lateral shift of the margin of the palate, the alveoli of the P1/ are oriented obliquely to the long axis of the cheek tooth row. This indicates that the individual was probably a male, because the holotype adult maxilla from Retama (RET 574), which is female, shows the alveoli of P1/ in line with the rest of the tooth row.

The roots of the zygomatic arch (facial crests) depart from the facial surface of the maxilla at an angle of some $30^{\circ}$ (affected by crushing) opposite the front of M1/ and the palatine foramen opens opposite the middle of $\mathrm{M} 2 /$.

Upper dentition. In FMH'14 2932, the upper deciduous canine is preserved on the right side and shows a compressed ovoid section (exaggerated by crushing), mesial and distal crista and an apically curved crownroot margin anteriorly (Fig. 4). The ventral enamel is lightly wrinkled longitudinally. The crown morphology resembles that of adult female individuals, but this is usual among suids the male deciduous canine looking like adult female canines. 
There is a confluent double alveolus for the $\mathrm{P} 1 /$, the anterior part being larger than the posterior part. It is located behind the canine and slightly lateral from the line of the cheek teeth. There is a diastema of $11 \mathrm{~mm}$ between the distal root of the P1/ and the anterior root of the $\mathrm{P} 2 /$. The remainder of the cheek teeth are in contact with each other.

The D2/ has a prominent main cusp with an oblique anterior crista ending at the mesio-lingual corner of the tooth, a strong posterior crista laterally, which joins a cingular crest distally. The latter structure curves lingually and then anteriorly, closing off a shallow disto-lingual fovea.

The D3/ is heavily worn, and has a triangular occlusal outline. A remnant of the anterior crista is preserved, which blends into low but sharp buccal and lingual cingular crests. The lingual crest fades out distally, but the buccal one extends right along the outer surface of the tooth as a beaded ridge about $2 \mathrm{~mm}$ above the cervix.
The D4/s are heavily worn, but show a rectangular occlusal outline and a prominent beaded buccal cingulum. The wear on the crown has eradicated almost all the structure, but it is possible to make out the outline of a large mesial crista leading mesio-lingually from the apex of the hypocone, which thereby almost closes off the mesial end of the median transverse valley.

Specimen FMH'14 2085 is a slightly damaged but lightly worn right D4/ (Fig. 10). It shows a more primitive morphology than the permanent molars, in particular its better defined Fürchen and crista. The paracone shows a prominent "zygodont" crest posteriorly that descends directly distally into the median transverse valley where it is joined by a mirror image anterior crest from the metacone. The pre-crista of the hypocone is well developed and extends across the median transverse valley, blocking it off at its lingual end. The mesial and distal cingula are well developed with beaded edges. The buccal side of the tooth is damaged.

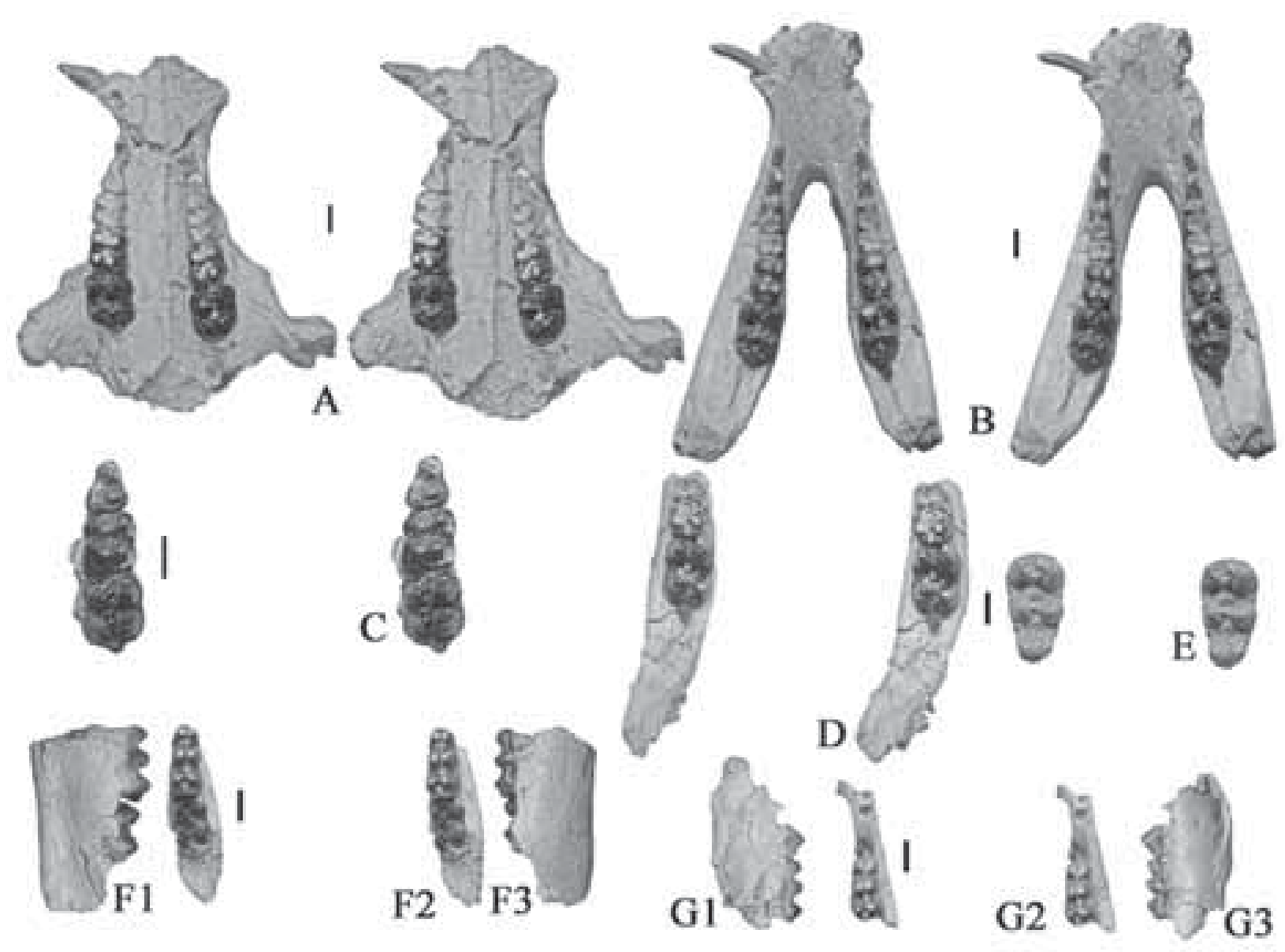

Figure 4. Listriodon retamaensis from Mahou, Madrid (Spain). All specimens have the prefix MNCN FMH'14. a) 2932, male juvenile snout with mixed dentition. b) 3559, male juvenile mandible with mixed dentition. c) 3202, right juvenile maxilla containing D3/-D4/, M1/. d) 3748, juvenile left mandible containing m/1-m/2. e) 3748, left $\mathrm{m} / 3$ from crypt in (D). f) 1905, juvenile right mandible containing d/4-m/1. g) 3096, juvenile right mandible containing $\mathrm{d} / 3-\mathrm{d} / 4$. All views are stereo occlusal views, except for F1 and G1: lingual as well as F3 and G3: buccal views. Scale bars $=10 \mathrm{~mm}$. 
FMH'14 3623 is an unworn left I1/ missing a small chip of enamel distally (Fig. 5). In lingual view, the crown is spatulate, with a prominent finely beaded lingual cingulum extending along the entire length of the tooth. The apex of the crown is subdivided into three main parts or lobes by deep incisions in the surface of the tooth. The mesial lobe has three beads, the central one is not subdivided, whereas the distal lobe is marked by a long series of crenulations (12 at least). On the buccal aspect of the tooth, there are remnants of cingula mesially and distally. The mesial cingulum is well developed and has a crenulated margin. The distal cingulum is weaker, but shows at least five crenulations.

The permanent upper canines are represented by two male specimens (3247 and 4075) (Fig. 8) and one female (4218) (Fig. 6). The male canine is hypselodont with open roots, has a strong buccally concave curvature, a prominent buccal groove and a clear mesial wear facet caused by abrasion against the lower canine. The female canine has a small crown supported by a long root, which is broken at the apex, but was probably closed. The crown is triangular in occlusal view, with the buccal side almost flat and the mesial and distal surfaces meeting in a rounded junction. There is a pre-crista, which has been almost completely removed by wear against the lower canine. The post-crista is sharp and ends cervically in a low swelling. There is a longitudinal groove on the buccal side of the root and a shallower less continuous one on the mesio-lingual part of the root. This morphology reveals that the ancestral canines in Listriodon possessed two confluent roots. The gingival level in this tooth is visible where the polished, exposed surface of the tooth passes into unpolished, rugose root surface. This reveals that the gingiva was located much further towards the apex of the root on the lingual side of the tooth (30 $\mathrm{mm}$ from crown apex to gingival level) than on the buccal side (16 $\mathrm{mm}$ from crown apex). This disposition indicates that the tooth was not vertical in the jaw, but must have slanted laterally, thereby making what would normally be the lingual surface the ventral one, and what, in a vertical tooth, would be lateral becomes dorsal.

There are two specimens of P1/ from Mahou (3989 and 3959) which have a crown that is considerably smaller than the two roots that support it (Fig. 7). The crown is rounded triangular in occlusal view, and shows a prominent main cusp on the buccal side, with a short mesial crista and a longer distal crista arranged slightly obliquely with respect to the long axis of the tooth. There is a low lingual cingulum, which closes off a small mesial fovea and a larger distal one, forming a disto-lingual basin that is bordered distally by a swollen cingulum. There are two peculiar aspects of this tooth, seen in all samples, including the holotype from Retama. One is that the crown is smaller than the roots, and the other is that a large part of the roots is polished by abrasion, probably by food. The polishing process has worn away some root mass, such that there is a prominent wavy ridge well beneath cervix marking the level of the gingiva, beneath which normal unpolished root surfaces are evident.

The only specimens of $\mathrm{P} 2 /$ from Mahou are in crypto (specimen 2932) such that their crown morphology is not visible.

FMH'14 3615 is a left P3/ in light wear (Fig. 5). The crown is triangular in occlusal outline, with rounded corners. There are two roots, an anterior one, which is circular in section with a distal groove, and a distal one, which is oval and transversely oriented. The main cusp has an apical wear facet, and a large anterior facet, which has worn away the anterior cingulum. There is a discontinuous beaded buccal cingulum and the lingual cingulum is continuous. The post-crista of the main cusp ends in a low distal cusplet (hint of a metacone). Lingually there is another low cusp inside the lingual cingulum that borders a large fovea, or basin, located between it, the main cusp and the distal cingulum.

FMH'14 3617 is a left P3/ and evidently represents the same individual as the $\mathrm{P} 2 /$ described above (Fig. 5). The interstitial facets are compatible with each other, as is the stage of wear. There are two roots, the anterior one circular in outline with a deep distal groove, the distal one swollen C-shaped in section with the opening of the " $\mathrm{C}$ " pointing anteriorly. The basic elements of the crown are the same as those observed in the $\mathrm{P} 2 /$, but the tooth is broader relative to its length. The buccal cingulum is continuous from front to back, but weakens beneath the main cusp.

FMH'14 3615 is a left P4/ that evidently represents the same individual as the $\mathrm{P} 2 /$ and $\mathrm{P} 3 /$ described above (for the same reasons). There are three roots, two small circular buccal ones, and a larger swollen C-shaped lingual one. The buccal half of the tooth is comprised of two closely appressed cusps, the paracone and metacone, as shown by the presence of a vertical groove on the buccal surface of the crown. The lingual half of the tooth is composed of a single main cusp, the protocone, bordered by a complete lingual cingulum that wraps around the protocone mesially and distally, blending into the mesial and distal cingula. The buccal cingulum is interrupted beneath the paracone, where its place is taken by a low swollen ridge. There is a slit-like fovea between the metacone and protocone, which opens distally. The paracone sends a broad crest (deeply worn) towards an anterior accessory cusplet in the midline of the crown.

The M1/ is deeply worn, but shows remnants of four main cusps and three sagittally positioned cusplets (anterior, median and posterior accessory cusplets). The occlusal outline of the tooth is rectangular. There is a prominent beaded buccal cingulum, which extends distally to fuse into the distal cingulum. Anteriorly it joins the mesial cingulum. The pre-crista of the hypocone is broad and extends mesiolingually where it joins a cingular remnant surviving on the posterior face of the protocone. 

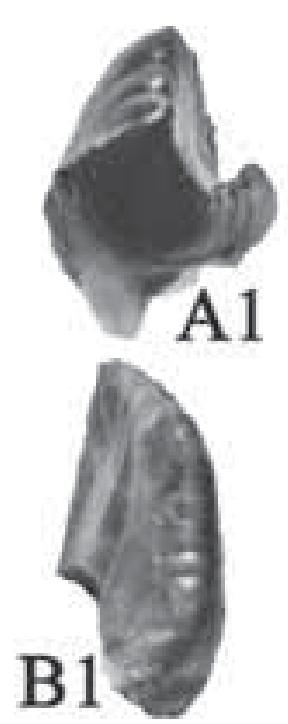
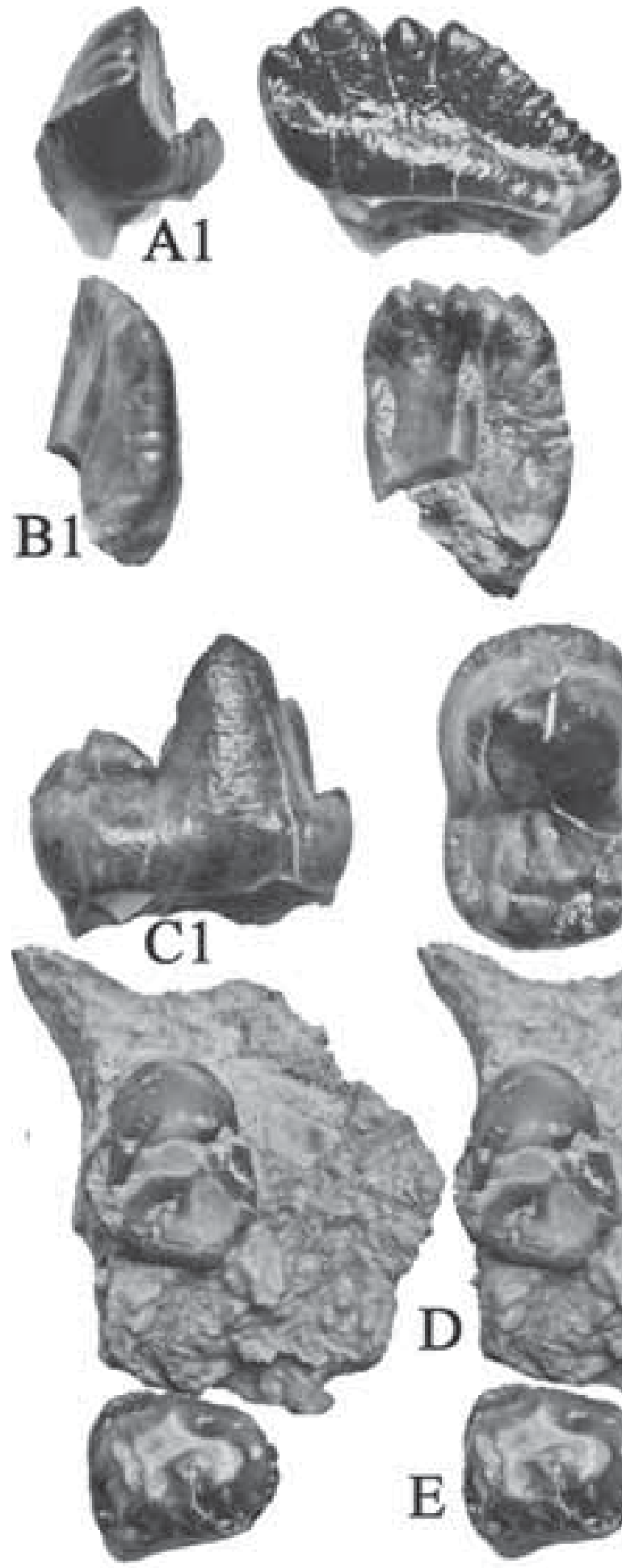
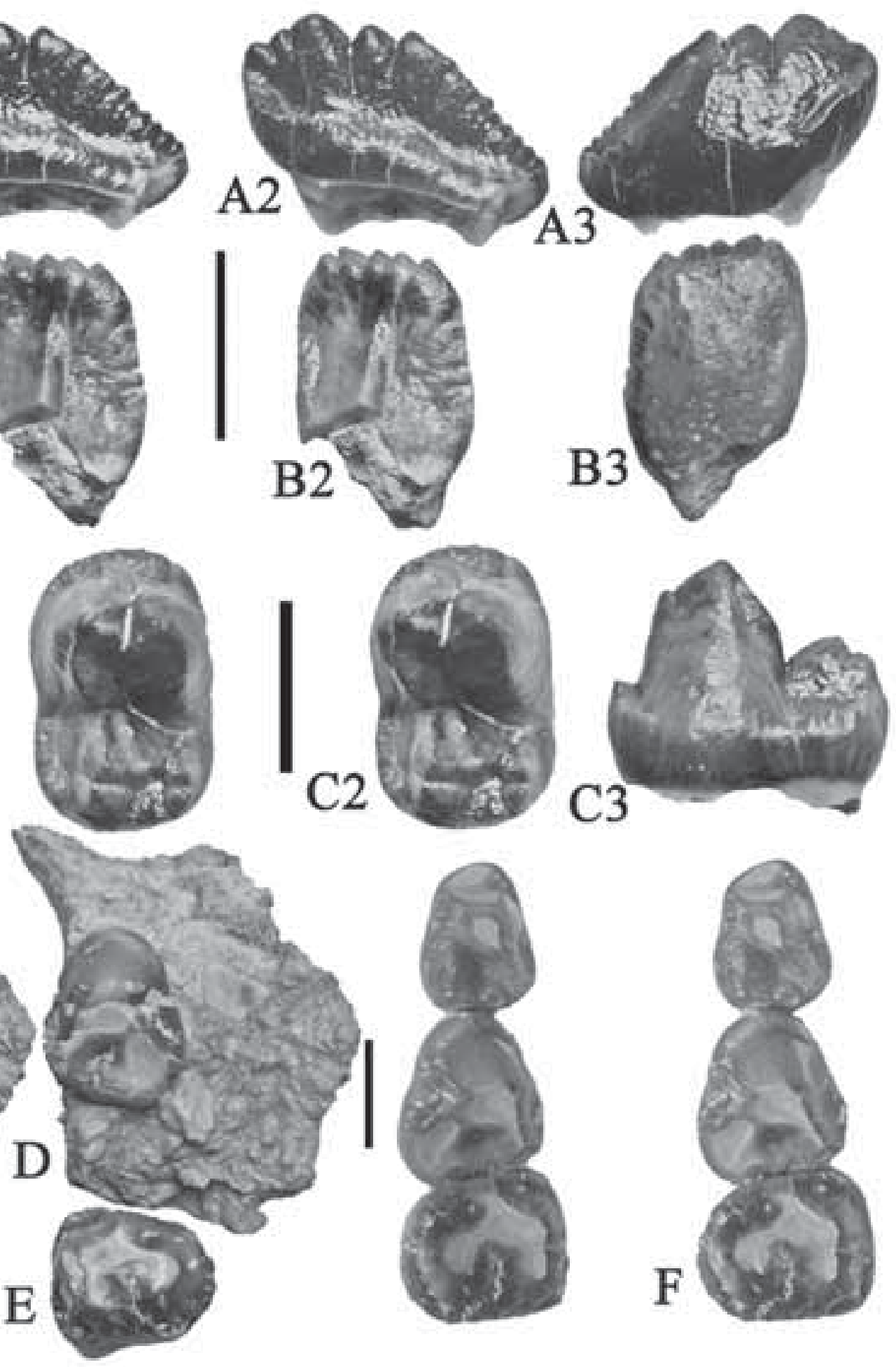

Figure 5. Listriodon retamaensis from Mahou, Madrid (Spain). All specimens have the prefix MNCN FMH'14. a) 3623, left I1/ in mesial (A1), stereo lingual view (A2), and labial (A3) view. b) 3399, right i/2 in distal (B1), stereo lingual (B2), and labial (B3) views. c) 3338, left p/4 in lingual (C1), stereo occlusal (C2), and buccal (C3) views. d) 3570, right maxilla fragment containing P3/, stereo occlusal view. e) 3569, right P4/ stereo occlusal view. f) 3615+3617, left P2/-P4/ stereo occlusal view. Scale bars $=10 \mathrm{~mm}$. 


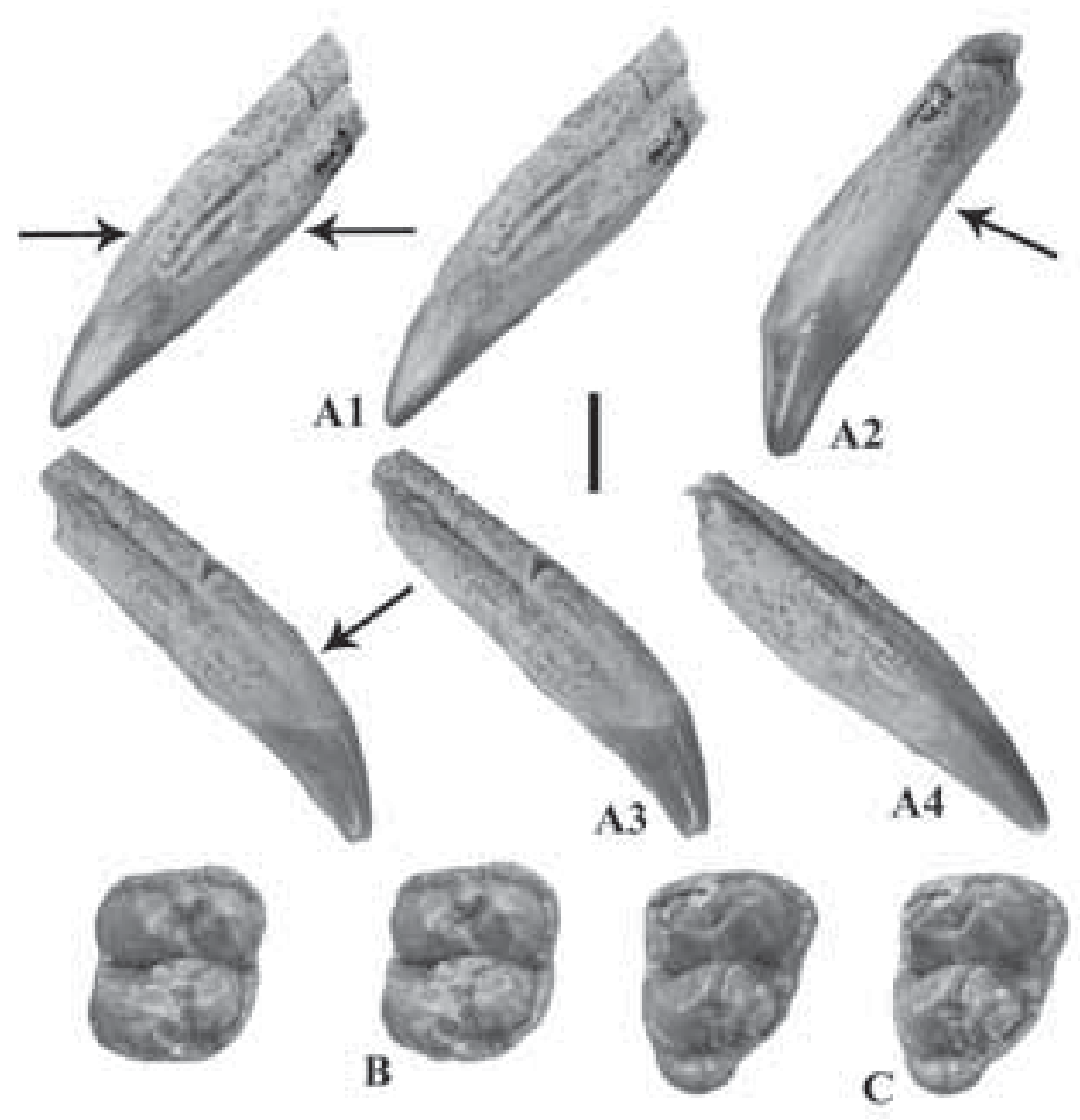

Figure 6. Listriodon retamaensis from Mahou, Madrid (Spain). a) MNCN 4218, female right upper canine in stereo anterior view (A1), lingual view (A2), stereo buccal view (A3), and posterior view (A4). b) 4081, left M2/ stereo occlusal view. c) 4236, left M3/ stereo occlusal view. Arrows show gingival levels in the canine. Scale bar $=10 \mathrm{~mm}$.

Figure 7. Listriodon retamaensis from Mahou, Madrid (Spain). Upper deciduous and permanent teeth. a) MNCN FMH'14 3989, left P1/ in buccal (A1), stereo occlusal (A2), and lingual (A3) views. b) 3959 , right $\mathrm{P} 1 /$ in lingual (B1), stereo occlusal (B2), and buccal (B3) views. c) 3492 , left $\mathrm{d} / 2$ in lingual $(\mathrm{C} 1)$, stereo occlusal (C2), and buccal (C3) views. d) 2135 , left D3/ in stereo occlusal (D1), and buccal (D2) views. e) 4195 , right $\mathrm{M} 1 /$ in stereo occlusal (E1), and buccal (E2) views. Arrows show gingival level in anterior teeth. Scale bar $=10 \mathrm{~mm}$.
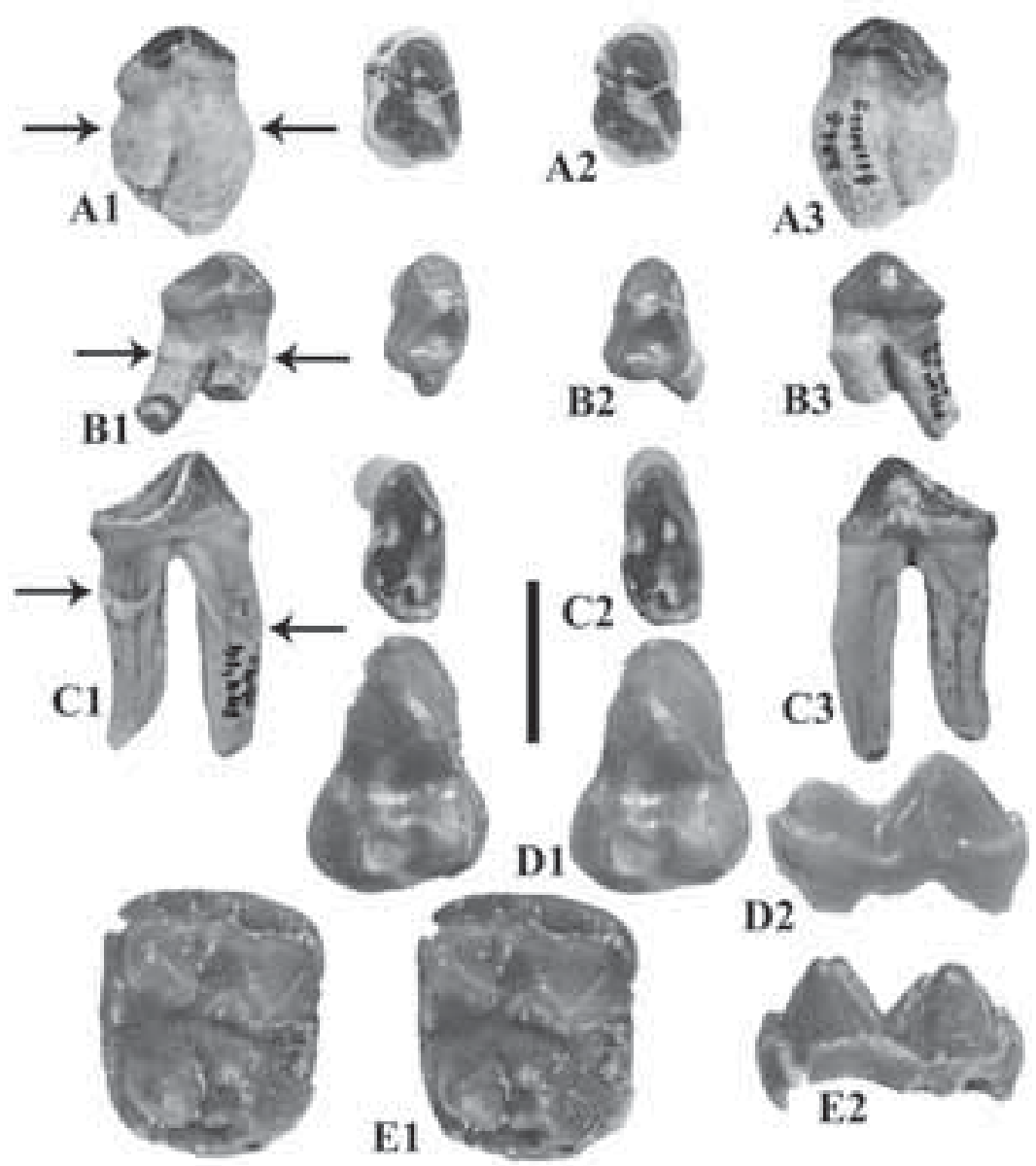

E1

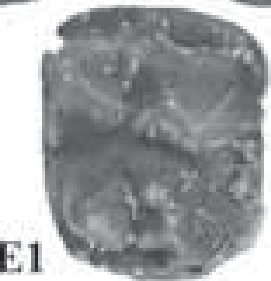




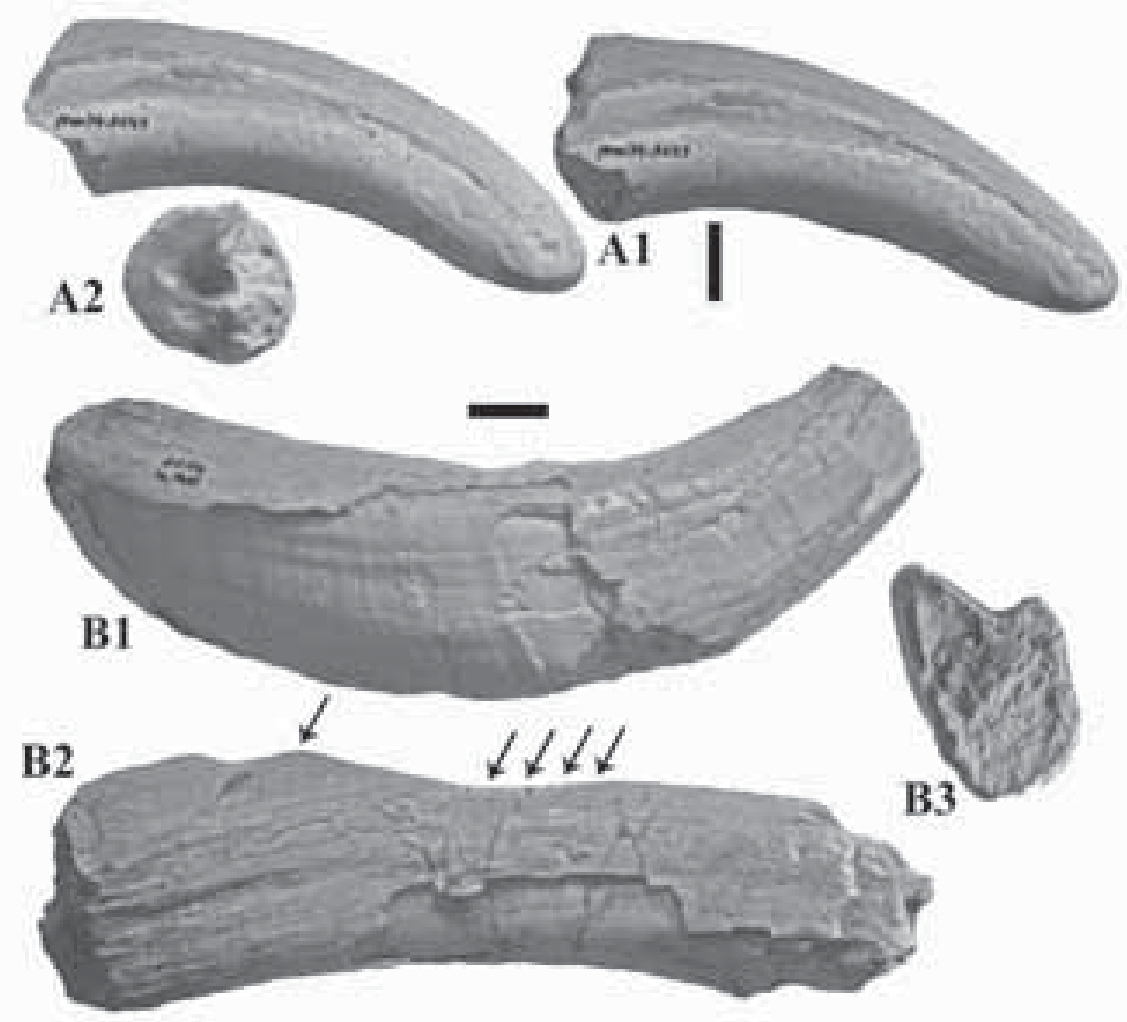

Figure 8. Listriodon retamaensis from Mahou, Madrid (Spain). Upper male canines. a) 3248, right canine tip, stereo dorsal view (A1), and section (A2). b) 4075, right upper canine in anterior view (B1), dorsal view (B2), and section (B3). Arrows show successive wear facets caused by abrasion against the lower canine. Scale bar $=10 \mathrm{~mm}$.

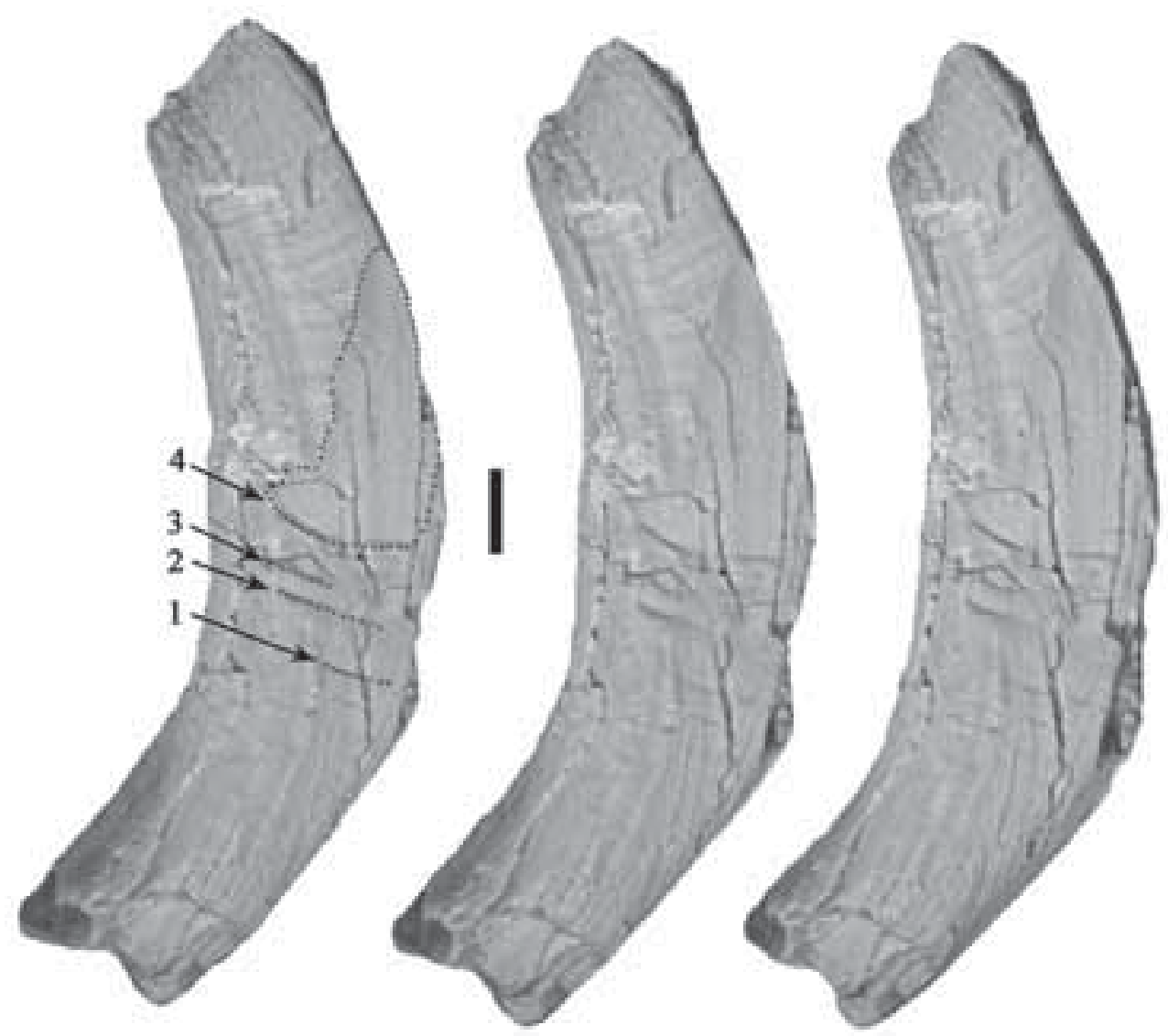

Figure 9. MNCN FMH'14 4075, Listriodon retamaensis from Mahou, Madrid (Spain). Upper male canine showing successive wear facets caused by abrasion against the lower canine (dotted lines). The root is at the top of the page. Stereo views. Scale bar $=10 \mathrm{~mm}$. 

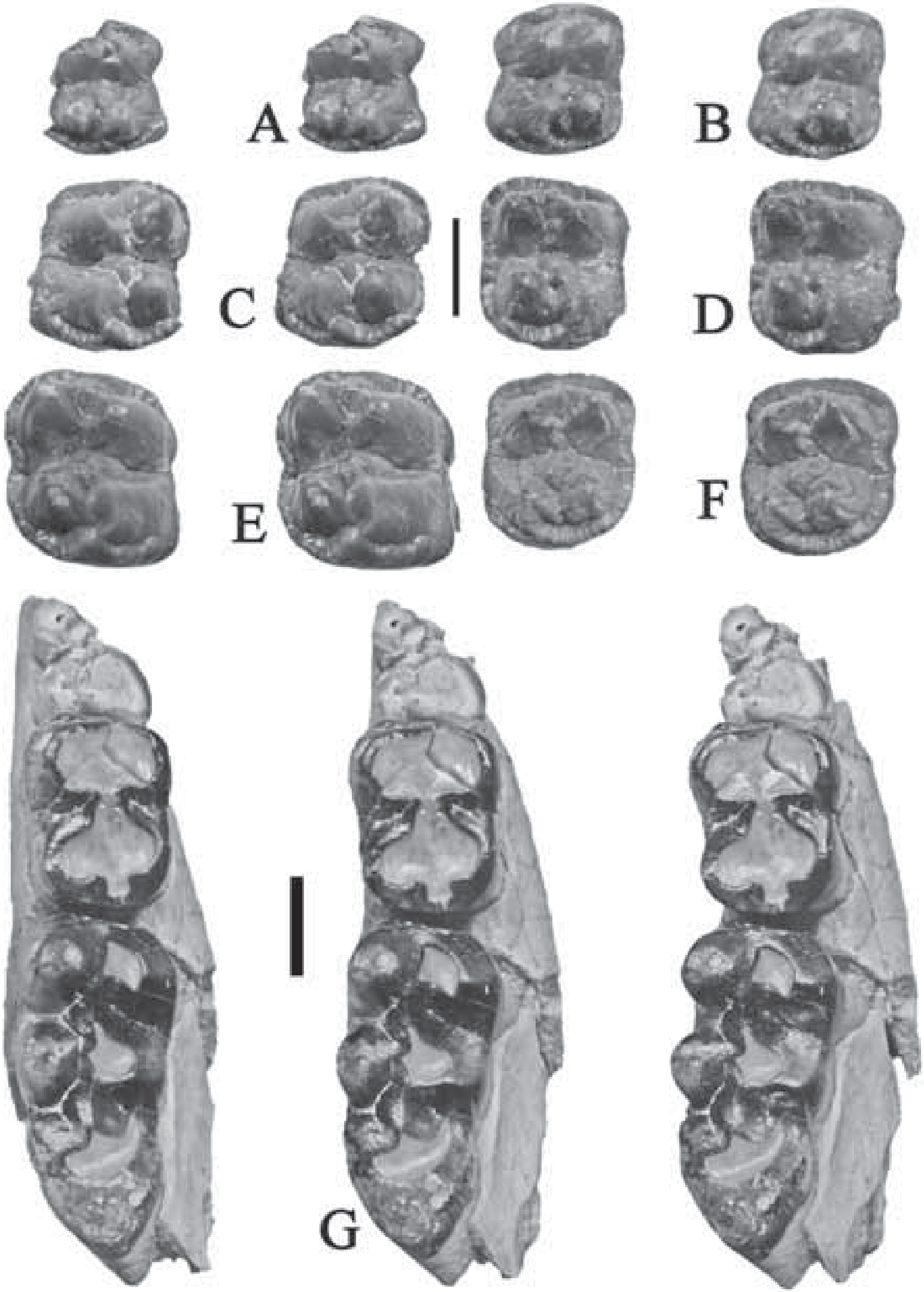

Figure 10. Stereo occlusal views of teeth of Listriodon retamaensis from Mahou, Madrid (Spain). All specimens have the prefix MNCN FMH'14. a) 2085, right D4/. b) 1618, left D4/. c) 690, left M1/. d) 3348, right M1/. e) 3762, right M2/. f) 1617, left M1/. g) 2715 , right mandible containing worn $\mathrm{m} / 1-\mathrm{m} / 3$. Note the extra cusplet behind the talonid of $\mathrm{m} / 3$. Scale bars $=10 \mathrm{~mm}$. 
The M2/ in specimen 2932 has just entered wear, leaving all the fine details of the crown to be observed. The occlusal outline is rectangular with the second loph as broad as the first one. There are four sub-equal main cusps, a prominent median accessory cusplet, and smaller anterior and diminutive posterior accessory cusplets, arranged along the midline of the tooth. There are welldefined mesial, buccal and distal cingula, which have a crenulate or beaded edge. The Fürchen of the main cusps are weakly incised, leaving the buccal cusps (paracone, metacone) almost perfectly conical. The paracone sends a broad crista lingually to join the rear of the anterior accessory cusplet, which lies between the anterior parts of the paracone and protocone, thereby forming a loph, behind which is a shallow slit-like fovea that opens distally into the median transverse valley. The protocone sends a broad crista lingually, the base of which curves distally into the median transverse valley, but not blocking it. The hypocone has a broad pre-crista that extends anterolingually to terminate at the lingual end of the median transverse valley where it almost links to a small distal crista at the base of the protocone. The median accessory cusplet is large and nearly blocks the median transverse valley, leaving a slit between the anterior and posterior halves of the tooth. There is a posterior fovea between the metacone and the hypocone, which opens distally via a slit-like valley that descends into the zone between the rear of the metacone and the distal cingulum.

The M3/ (4236) has a low but well-developed talon cusplet behind the hypocone and slightly to the buccal side (Fig. 6). The anterior two lophs of the crown are like the $\mathrm{M} 2 /$ with the exception that the metacone is slightly reduced in size, making the second loph of the M3/ noticeably narrower than the first one.

In summary, the upper cheek teeth from Mahou can be described as bunolophodont, presaging the fully lophodont morphology that characterises Listriodon splendens, for example.

Mandible. FMH'14 3559 is a juvenile mandible containing the partly erupted left canine with a small wear facet at its apex (the right canine lacks its apex). This is probably the same individual as 2932 (Fig. 4). The form of the canine indicates that this was a male individual. The deciduous cheek teeth and two of the permanent molars are fully erupted comprising left and right $\mathrm{d} / 2-\mathrm{d} / 4$ and $\mathrm{m} / 1-\mathrm{m} / 2$, whereas the left and right $\mathrm{i} / 2$, both $\mathrm{m} / 3 \mathrm{~s}$ are in crypt. There is an alveolus for the $\mathrm{p} / 1$ preserved just behind the canine on the left side and somewhat outside the line of the cheek teeth. The diastema between the $\mathrm{p} / 1$ and $\mathrm{d} / 2$ is $22 \mathrm{~mm}$ long. The rest of the lower cheek teeth are in contact with one another. The posterior end of the symphysis is beneath the front of the $\mathrm{d} / 2$.

FMH'14 3351 is the right half of a mandibular symphysis (Fig. 11). It shows a prominent alveolus for the right $\mathrm{p} / 1$ just behind the canine, which is hypselodont signifying a male individual. The disastema between $\mathrm{p} / 1$ and $\mathrm{p} / 2$ is $23+\mathrm{mm}$ ( $\mathrm{p} / 2$ is missing). There are three incisor alveoli, of which that for the $i / 3$ is appreciably smaller than the sub-equal alveoli for $i / 1$ and $i / 2$. The dorsal surface of the symphysis is relatively flat and in the incisor area is comprised of a rugose bone surface. Ventrally there is a foramen below the root apices of $i / 1$ and $i / 2$ and laterally there is a second foramen close to the canine alveolus.

Lower dentition. There are several juvenile lower jaws from Mahou. In specimen 3559, the $d / 2$ is a single cusped tooth with mesial and distal cristids, the latter one bifurcating basally with a short crest leading distolingually. There are short cingula ridges anteriorly extending a short way along the lingual and buccal sides of the tooth. There is a weak distal cingulum, which extends a short way anteriorly on the buccal surface of the tooth.

The $d / 3$ is a larger version of the $d / 2$ with a broader distal half. Wear has advanced to the stage where little morphology is left. The buccal surface shows vertically wrinkled enamel.

The $\mathrm{d} / 4$ is a three lobed tooth, with three roots buccally and two lingually. Wear has all but eradicated the cusp morphology.

In FMH'14 433, the $\mathrm{d} / 3$ is unworn and shows two postcristids bordering a distal basin in the centre of which is a low crest (Fig. 12). Each of the post-cristids has a low swollen tubercle at its distal extremity.

The $\mathrm{d} / 4$ in this specimen is moderately worn revealing that in Listriodon, the $\mathrm{d} / 4$ erupts and starts wearing before the $d / 3$ and $d / 2$ erupt. The first lophid has a large buccal cusp and a smaller lingual one, in front of which is a small, low, accessory tubercle, which joins the narrow mesial cingulum. The buccal cusp in contrast has a distolingual cristid, which ends in a low tubercle in the centre of the transverse valley between the first and second lophid and it has a remnant of a buccal cingulum that extends distally across the buccal end of the transverse valley. The second lophid has two cusps, a larger buccal one and a smaller lingual one. The buccal cusp has a small, low, pre-cristid. The third lophid is comprised of two cusps, a broad buccal one, which has prominent pre- and postcristids, the anterior one blocking the centre of the distal transverse valley, the posterior one forming a central distal cusplet. The buccal cingulum is strong at the ends of the second and third transverse valley, but fades out on the buccal side of the cusps.

The i/2 in FMH'14 3559 (Fig. 4) shows a distal lingual scoop and its apex and distal margins are crenulated.

The canines in specimens 2452 (Fig. 13) and 3351 are scrofic in section and hypselodont, signifying that the jaws belong to male individuals.

FMH'14 3478 is a young adult left mandible containing the three permanent molars. The $\mathrm{m} / 3$ was removed from its crypt, so it is in a completely unworn condition showing well the occlusal morphology, but the cervix was 


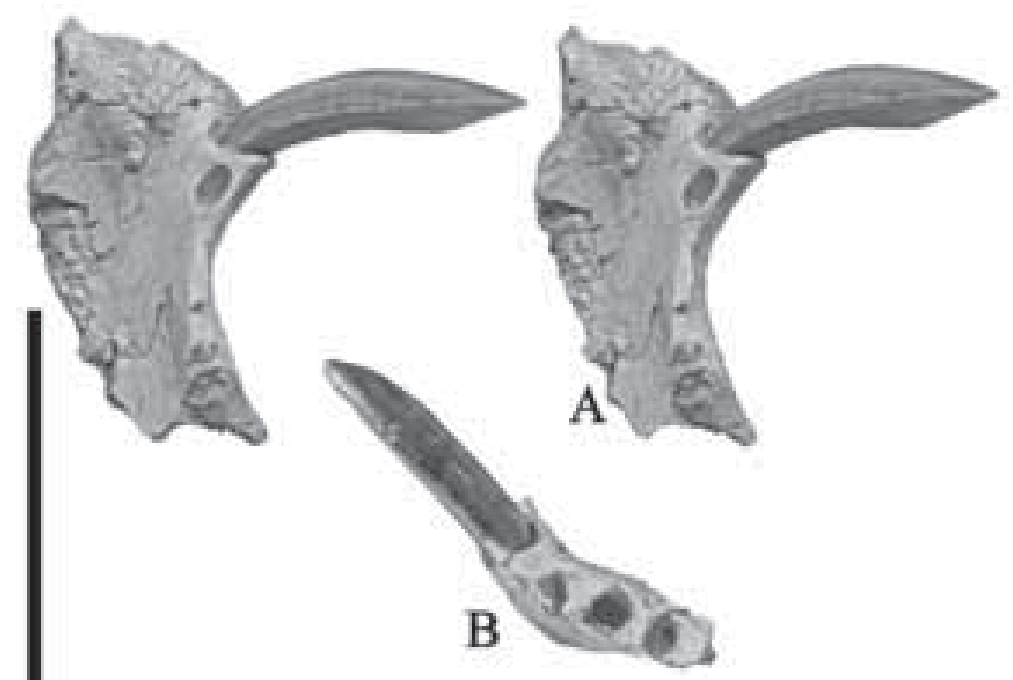

Figure 11. Listriodon retamaensis from Mahou, Madrid (Spain). MNCN FMH'14 3351, right mandibular symphysis containing male canine and alveolus of right $\mathrm{p} / 1$. Stereo occlusal view (A), anterior view (B), and stereo ventral view $(C)$. Scale bar $=10 \mathrm{~cm}$.
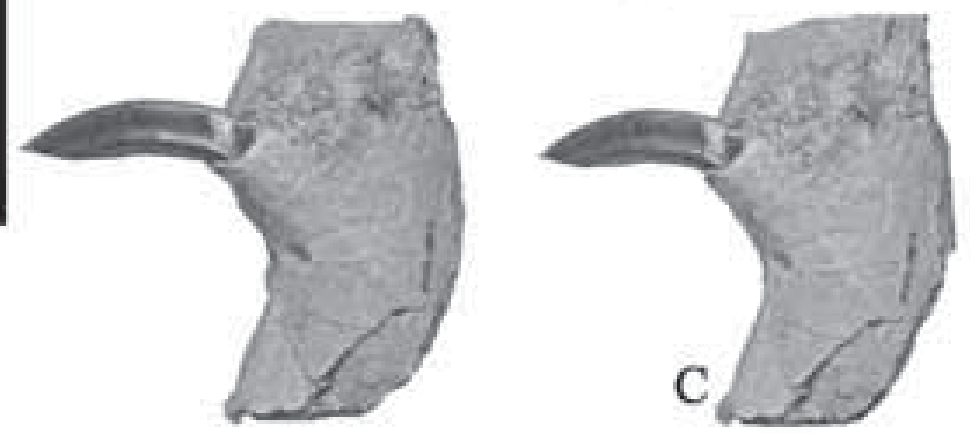

Figure 12. Listriodon retamaensis from Mahou, Madrid (Spain). MNCN FMH'14, juvenile mandibles. a) 2095, left mandible with $\mathrm{p} / 3-\mathrm{m} / 1$ in buccal (A1), stereo occlusal (A2) and lingual (A3) views. b) 433, right mandible with $\mathrm{d} / 2-\mathrm{d} / 4$ and $\mathrm{m} / 1$ in buccal (B1), stereo occlusal (B2), and lingual (B3) views. Scale bar $=10 \mathrm{~cm}$.
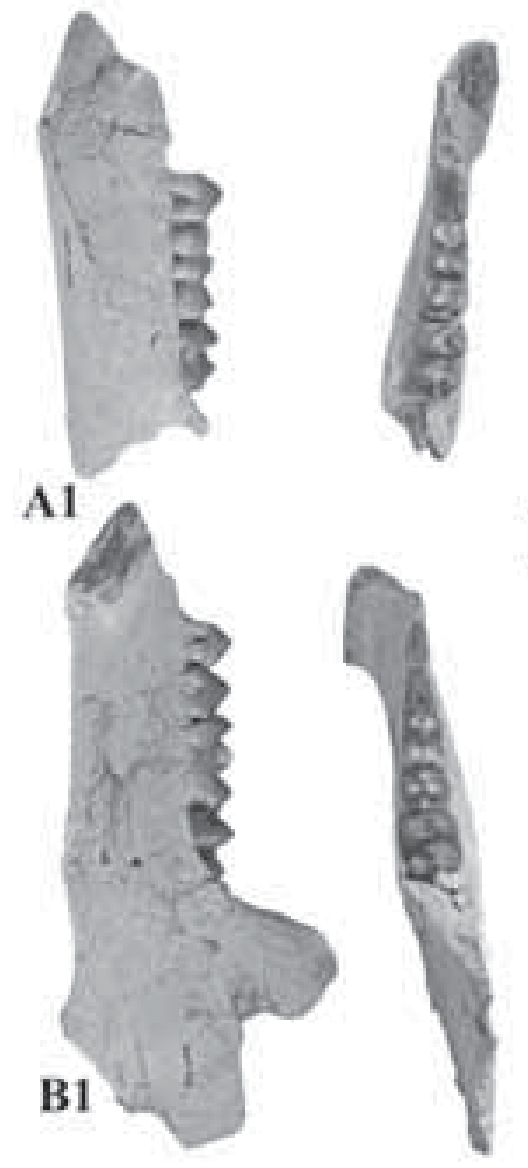

A2

A3

I
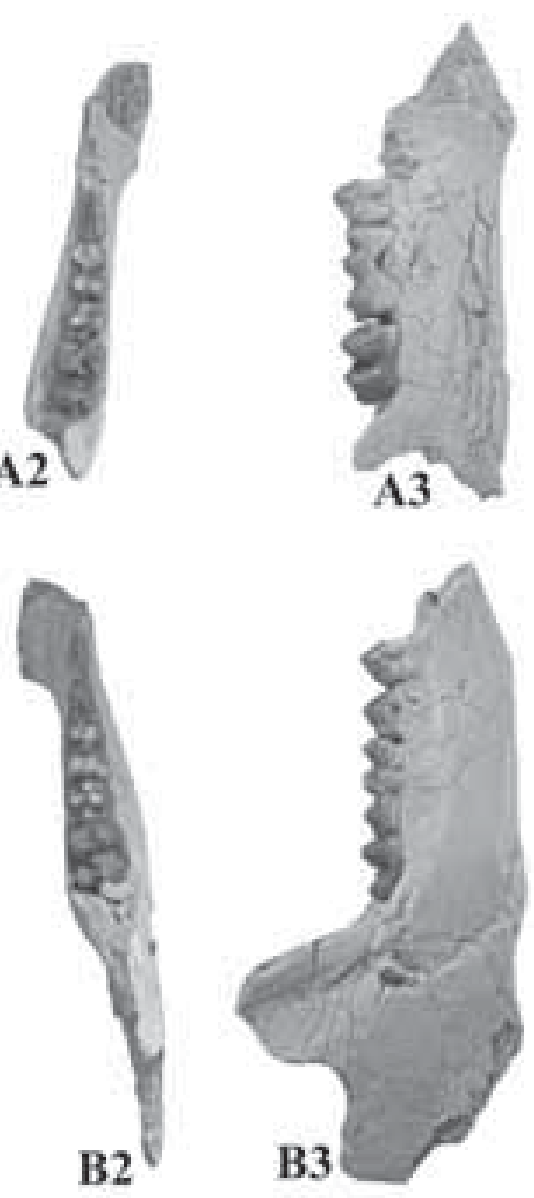
not completely formed distally. The mesial cingulum is complete and finely crenulated but does not extend onto the buccal side of the tooth. There are, however, cingular structures in the buccal end of the median and posterior transverse valleys and low "basal pillars" in the lingual ends of the same valleys. The two anterior lophids of the tooth are like those of the $\mathrm{m} / 2$, but there is a welldeveloped talonid behind the posterior accessory cusplet. The Fürchen of the main cusps are weakly incised, those on the distal side of the protoconid and metaconid being the most evident. The anterior accessory cusp is very small and closely applied to the protoconid. There is a shallow fovea between the two cusps of the first lophid. The second lophid comprises the entoconid and hypoconid, which are separated from each other by a slit. The hypoconid is closely applied to the median accessory cusplet anteriorly and the posterior accessory cusplet distally. These two accessory cusplets block the median and posterior transverse valleys respectively. The talonid consists of a centrally positioned main cusp flanked by coarsely beaded cingular ridges bucco-mesially and linguo-mesially.
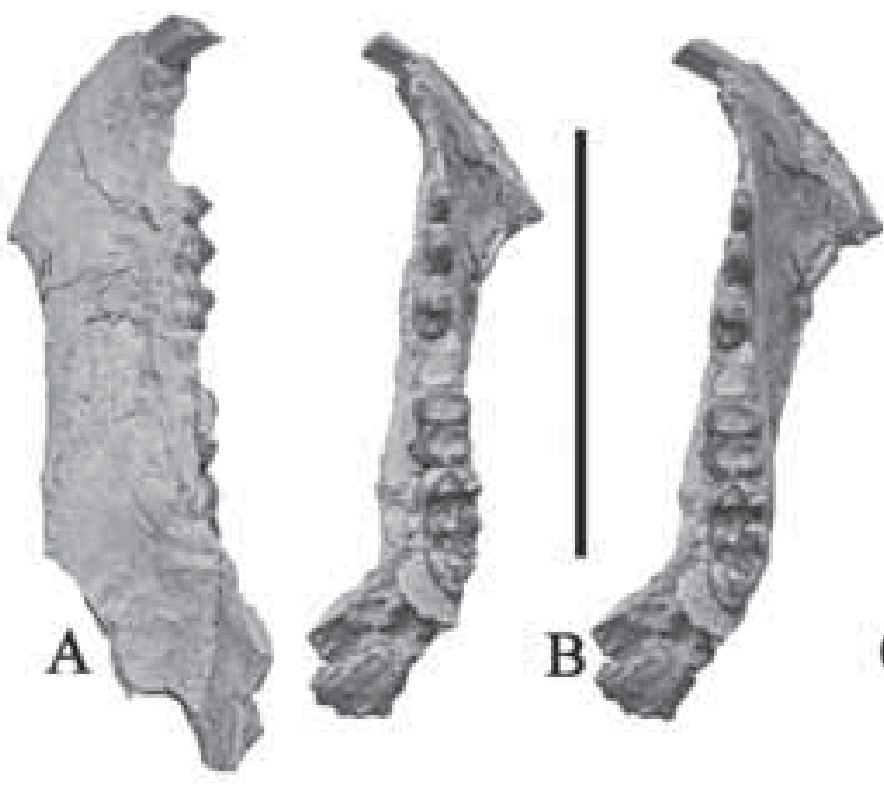

The $\mathrm{p} / 4$ has a prominent Innenhügel, worn at its apex, but still as tall as the protoconid, and there is a prominent but low, centrally positioned distal cusplet flanked buccally by a low beaded cingulum.

The crowns of $\mathrm{m} / 1$ and $\mathrm{m} / 2$ in this jaw are so deeply worn that little of interest remains to be observed. However it is possible to discern that the $\mathrm{m} / 1$ has two lophids and prominent median and posterior accessory cusplets. The anterior acessory cusplet is reduced in dimensions, but the mesial cingulum is well formed and complete from buccal to lingual. There is a cingular remnant in the buccal end of the median transverse valley.
The adult left mandible, FMH'14 2452 (Fig. 13) has deeply worn molars from which most of the morphological details have been eradicated. The rear of the symphysis is positioned beneath the front of the $\mathrm{p} / 3$. There is a pair of mental foramina beneath the diastema just above the level of the canine alveolus. The hypselodont canine, which is in situ in FMH'14 2452, but missing its apex, shows a scrofic section signifying its male status.

The single rooted $\mathrm{p} / 1$ alveolus in FMH'14 3351 is immediately behind the canine. The diastema between the $\mathrm{p} / 1$ alveolus and the $\mathrm{p} / 2$ is $24 \mathrm{~mm}$. The $\mathrm{p} / 2$ in FMH'14 2452 is a single cusped tooth posed on two roots, with well-formed distal cristid but none anteriorly, the front of the tooth being steep with a rounded profile. There is a weak lingual shelf distally and a poorly expressed buccal cingulum along the rear of the tooth.

The $p / 3$ in specimen 2452 is like the $p / 2$ but is longer and broader distally with a better expressed, but still shallow, disto-lingual shelf and weak buccal cingulum on the distal third of the tooth.
Figure 13. Listriodon retamaensis from Mahou, Madrid (Spain). MNCN FMH'14 2452, left male mandible containing $\mathrm{c} / \mathrm{m}, \mathrm{p} / 2-\mathrm{m} / 3$ in buccal (A), stereo occlusal (B), and lingual (C) views. Scale bar $=10 \mathrm{~cm}$.
The $m / 2$ is in medium wear and shows weakly expressed Fürchen and relatively well-developed connections between the protoconid and metaconid via the weak.

Post-cranial bones from Mahou. Mahou yielded several post-cranial elements which can be confidently attributed to Listriodon retamaensis on the basis of their dimensions and association with dental elements.

The radius (FMH'14 2741) is short and robust with deep trochlear grooves for the humerus proximally (Fig. 17). The surface of attachment for the ulna is broad and rugose, but shows no signs of the ulna having been fused to the 

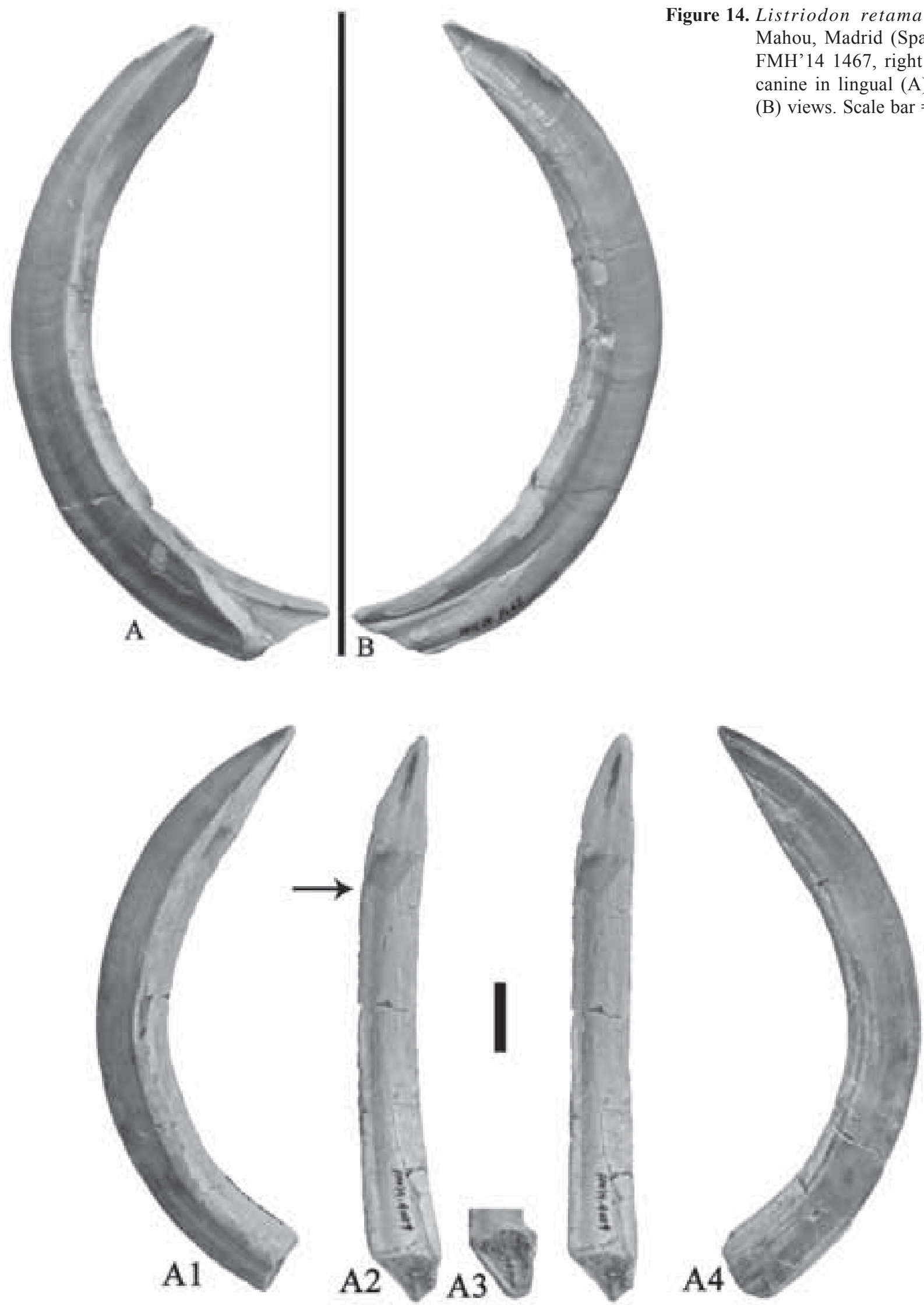

Figure 15. Listriodon retamaensis from Mahou, Madrid, Spain. MNCN FMH'14 4009, right lower male canine in labial (A1), stereo distal (A2) view, section at internal end of tooth (A3), and lingual (A4) views. Arrow shows the extent of the wear facet caused by contact with the upper canine. Scale bar $=10 \mathrm{~cm}$. 

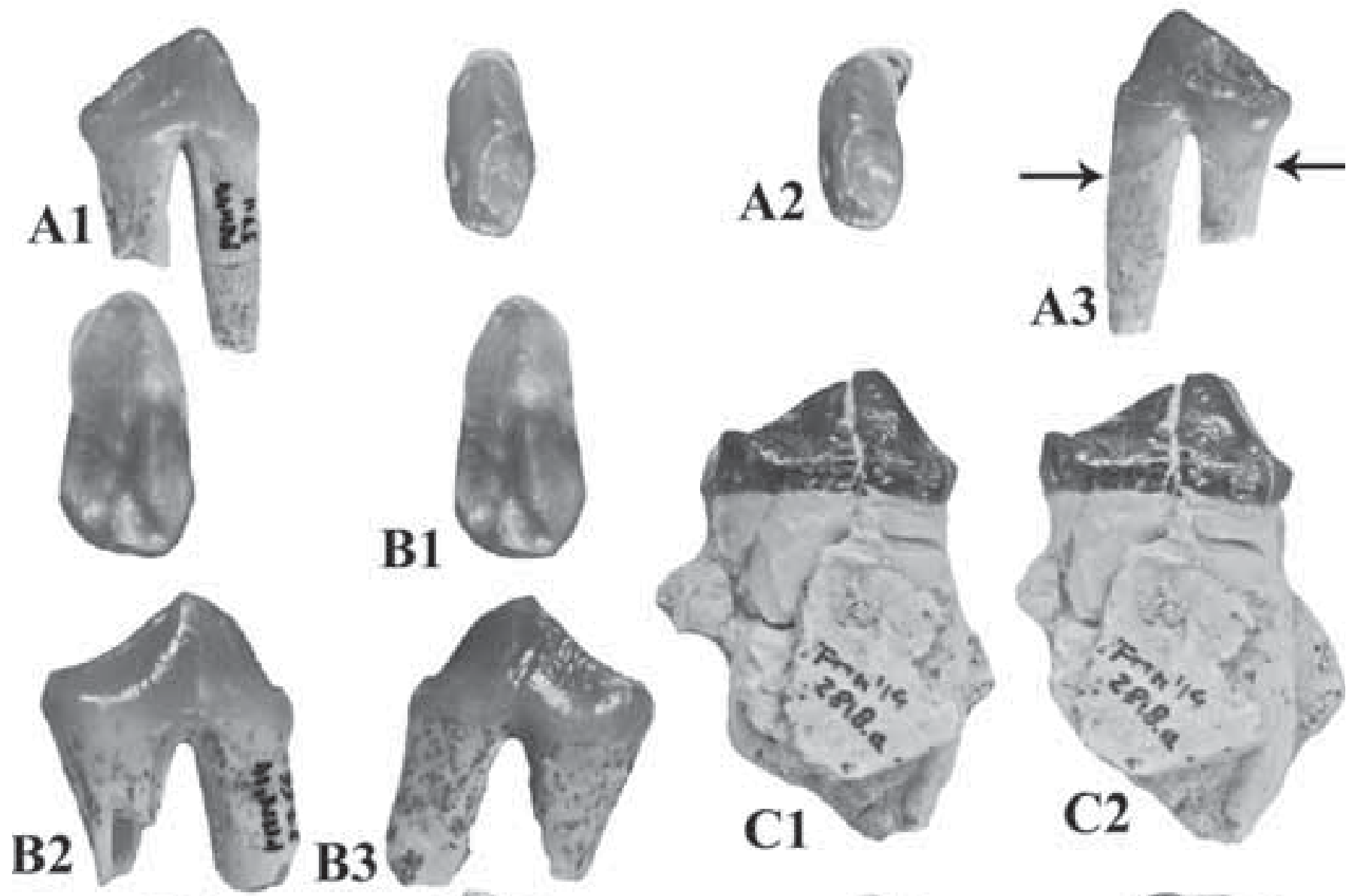

B3
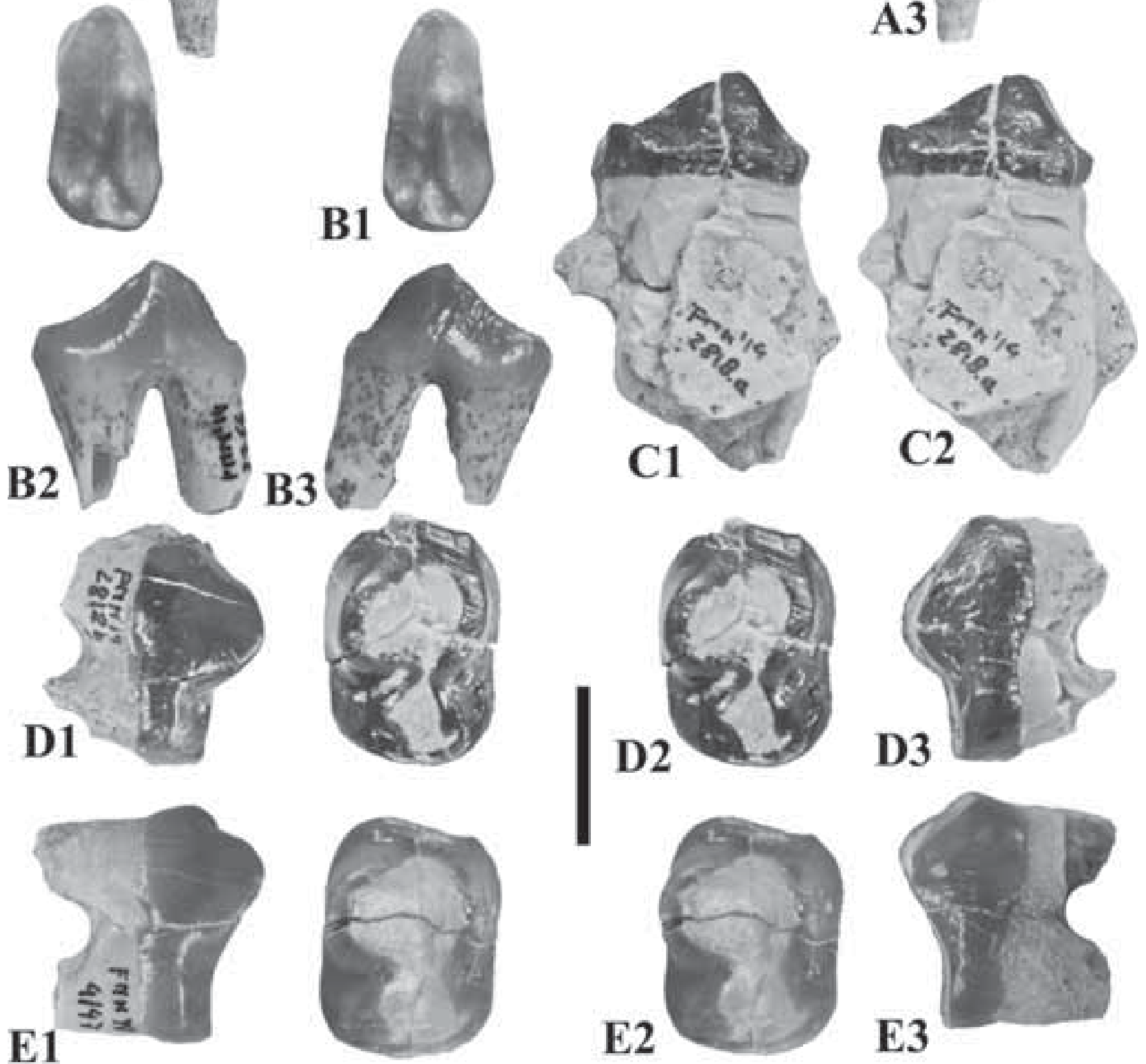

Figure 16. Listriodon retamaensis from Mahou, Madrid (Spain). Lower premolars and molars. a) 3711, left d/2 in buccal (A1), stereo occlusal (A2), and lingual (A3) views. b) 3766, right d/3 in stereo occlusal (B1), lingual (B2), and buccal (B3) views. c) $2818 \mathrm{a}$, right $\mathrm{p} / 3$ stereo buccal view. d) $2818 \mathrm{~b}$, right $\mathrm{p} / 4$ in lingual (D1), stereo occlusal (D2), and buccal (D3) views. e) 4147 , right $\mathrm{p} / 4$ in lingual (E1), stereo occlusal (E2), and buccal (E3) views. Scale bar $=10 \mathrm{~mm}$. 
Table 2. Measurements (in $\mathrm{mm}$ ) of the teeth of Listriodon retamaensis from Mahou, Madrid (Spain). lt: left; rt: right; --: no measurement possible.

\begin{tabular}{|c|c|c|c|}
\hline Catalogue & Tooth & $\begin{array}{l}\text { Mesio-distal } \\
\text { Length }\end{array}$ & Bucco-lingual Breadth \\
\hline MNCN FMH'14 3559 & $\mathrm{~d} / 2 \mathrm{lt}$ & 9.2 & 4.7 \\
\hline MNCN FMH'14 3559 & $\mathrm{~d} / 2 \mathrm{rt}$ & 9.7 & -- \\
\hline MNCN FMH'14 3492 & $\mathrm{~d} / 2 \mathrm{lt}$ & 10.0 & 4.9 \\
\hline MNCN FMH'14 3711 & $\mathrm{~d} / 2 \mathrm{lt}$ & 9.0 & 4.4 \\
\hline MNCN FMH'14 433 & $\mathrm{~d} / 2 \mathrm{rt}$ & 10.3 & 5.0 \\
\hline MNCN FMH'14 433 & $\mathrm{~d} / 3 \mathrm{rt}$ & 11.1 & 7.5 \\
\hline MNCN FMH'14 3559 & $\mathrm{~d} / 3 \mathrm{lt}$ & 12.0 & 6.3 \\
\hline MNCN FMH'14 3096 & $\mathrm{~d} / 3 \mathrm{rt}$ & 12.0 & 7.0 \\
\hline MNCN FMH'14 3559 & $\mathrm{~d} / 3 \mathrm{rt}$ & 11.1 & 6.2 \\
\hline MNCN FMH'14 3766 & $\mathrm{~d} / 3 \mathrm{rt}$ & 11.7 & 6.0 \\
\hline MNCN FMH'14 2059 & $\mathrm{~d} / 3 \mathrm{lt}$ & 11.2 & 6.1 \\
\hline MNCN FMH'14 2059 & $\mathrm{~d} / 4 \mathrm{lt}$ & 21.2 & 10.3 \\
\hline MNCN FMH'14 4421 & $\mathrm{~d} / 4 \mathrm{lt}$ & -- & 11.1 \\
\hline MNCN FMH'14 433 & $\mathrm{~d} / 4 \mathrm{rt}$ & 21.0 & 11.0 \\
\hline MNCN FMH'14 3559 & $\mathrm{~d} / 4 \mathrm{lt}$ & 22.0 & 11.0 \\
\hline MNCN FMH'14 1905 & $\mathrm{~d} / 4 \mathrm{rt}$ & 22.5 & 10.8 \\
\hline MNCN FMH'14 3096 & $\mathrm{~d} / 4 \mathrm{rt}$ & 20.5 & 11.0 \\
\hline MNCN FMH'14 3559 & $\mathrm{~d} / 4 \mathrm{rt}$ & 21.0 & 10.6 \\
\hline MNCN FMH'14 3399 & $\mathrm{i} / 2 \mathrm{rt}$ & 9.7 & 7.0 \\
\hline MNCN FMH'14 3559 & $\mathrm{i} / 2 \mathrm{rt}$ & 10.3 & 8.5 \\
\hline MNCN FMH'14 2452 & $\mathrm{c} / \mathrm{m}$ lt & 12.5 & 10.1 \\
\hline MNCN FMH'14 1467 & $\mathrm{c} / \mathrm{m} \mathrm{rt}$ & 13.0 & 10.7 \\
\hline MNCN FMH'14 3351 & $\mathrm{c} / \mathrm{m} \mathrm{rt}$ & 12.2 & 10.6 \\
\hline MNCN FMH'14 4009 & $\mathrm{c} / \mathrm{m} \mathrm{rt}$ & 11.6 & 10.2 \\
\hline MNCN FMH'14 2452 & $\mathrm{p} / 2 \mathrm{lt}$ & 11.4 & 6.0 \\
\hline MNCN FMH'14 2452 & $\mathrm{p} / 3 \mathrm{lt}$ & 14.2 & 9.1 \\
\hline MNCN FMH'14 4147 & $\mathrm{p} / 3 \mathrm{rt}$ & -- & 8.4 \\
\hline MNCN FMH'14 2818 & $\mathrm{p} / 3 \mathrm{rt}$ & 15.5 & 9.0 \\
\hline MNCN FMH'14 2818 & $\mathrm{p} / 4 \mathrm{rt}$ & 16.2 & 11.8 \\
\hline MNCN FMH'14 4147 & $\mathrm{p} / 4 \mathrm{rt}$ & 16.0 & 11.9 \\
\hline MNCN FMH'14 2452 & $\mathrm{p} / 4 \mathrm{lt}$ & 16.0 & 11.8 \\
\hline MNCN FMH'14 3338 & $\mathrm{p} / 4 \mathrm{lt}$ & 16.5 & 11.0 \\
\hline MNCN FMH'14 2452 & $\mathrm{~m} / 1 \mathrm{lt}$ & -- & 13.0 \\
\hline MNCN FMH'14 3478 & $\mathrm{~m} / 1 \mathrm{lt}$ & 17.8 & 13.4 \\
\hline MNCN FMH'14 3559 & $\mathrm{~m} / 1 \mathrm{lt}$ & 18.1 & 12.9 \\
\hline MNCN FMH'14 1905 & $\mathrm{~m} / 1 \mathrm{rt}$ & 18.7 & 11.7 \\
\hline MNCN FMH'14 2715 & $\mathrm{~m} / 1 \mathrm{rt}$ & -- & 12.4 \\
\hline MNCN FMH'14 3559 & $\mathrm{~m} / 1 \mathrm{rt}$ & 18.7 & 13.0 \\
\hline MNCN FMH'14 2059 & $\mathrm{~m} / 1 \mathrm{lt}$ & 16.6 & 11.7 \\
\hline MNCN FMH'14 433 & $\mathrm{~m} / 1 \mathrm{rt}$ & 16.5 & 12,3 \\
\hline MNCN FMH'14 2452 & $\mathrm{~m} / 2 \mathrm{lt}$ & 20.2 & 15.7 \\
\hline MNCN FMH'14 3478 & $\mathrm{~m} / 2 \mathrm{lt}$ & 22.2 & 16.4 \\
\hline MNCN FMH'14 3559 & $\mathrm{~m} / 2 \mathrm{lt}$ & 22.0 & 17.2 \\
\hline MNCN FMH'14 2715 & $\mathrm{~m} / 2 \mathrm{rt}$ & 20.5 & 15.1 \\
\hline
\end{tabular}




\begin{tabular}{|c|c|c|c|}
\hline Catalogue & Tooth & $\begin{array}{l}\text { Mesio-distal } \\
\text { Length }\end{array}$ & Bucco-lingual Breadth \\
\hline MNCN FMH'14 3559 & $\mathrm{~m} / 2 \mathrm{rt}$ & 22.5 & 16.0 \\
\hline MNCN FMH'14 5318 & $\mathrm{~m} / 2 \mathrm{lt}$ & -- & 15.0 \\
\hline MNCN FMH'14 2452 & $\mathrm{~m} / 3 \mathrm{lt}$ & 33.6 & 17.6 \\
\hline MNCN FMH'14 3478 & $\mathrm{~m} / 3 \mathrm{lt}$ & 31.2 & 18.3 \\
\hline MNCN FMH'14 2715 & $\mathrm{~m} / 3 \mathrm{rt}$ & 34.0 & 17.3 \\
\hline MNCN FMH'14 2932 & $\mathrm{D} 2 / \mathrm{lt}$ & 10.8 & 6.2 \\
\hline MNCN FMH'14 2932 & $\mathrm{D} 2 / \mathrm{rt}$ & 11.5 & 6.2 \\
\hline MNCN FMH'14 2932 & $\mathrm{D} 3 / \mathrm{lt}$ & 15.4 & 10.6 \\
\hline MNCN FMH'14 3202 & $\mathrm{D} 3 / \mathrm{lt}$ & 14.7 & 10.9 \\
\hline MNCN FMH'14 2932 & $\mathrm{D} 3 / \mathrm{rt}$ & 14.5 & 10.8 \\
\hline MNCN FMH'14 2135 & $\mathrm{D} 3 / \mathrm{lt}$ & 14.4 & 10.6 \\
\hline MNCN FMH'14 1618 & D4/ lt & 15.5 & 13.8 \\
\hline MNCN FMH'14 2932 & $\mathrm{D} 4 / \mathrm{lt}$ & 14.5 & 13.6 \\
\hline MNCN FMH'14 3202 & $\mathrm{D} 4 / \mathrm{lt}$ & 14.2 & 13.2 \\
\hline MNCN FMH'14 2085 & $\mathrm{D} 4 / \mathrm{rt}$ & 14.1 & -- \\
\hline MNCN FMH'14 2932 & $\mathrm{D} 4 / \mathrm{rt}$ & 14.2 & 14.0 \\
\hline MNCN FMH'14 3623 & $\mathrm{I} 1 / \mathrm{lt}$ & 19.0 & 8.6 \\
\hline MNCN FMH'14 4075 & $\mathrm{CM} / \mathrm{rt}$ & 34.5 & 22.4 \\
\hline MNCN FMH'14 3248 & $\begin{array}{l}\mathrm{CM} / \mathrm{rt} \text { (apex } \\
\text { only) }\end{array}$ & 23.8 & 21.4 \\
\hline MNCN FMH'14 4218 & $\mathrm{Cf} / \mathrm{rt}$ & 10.0 & 9,2 \\
\hline MNCN FMH'14 3959 & $\mathrm{P} 1 / \mathrm{rt}$ & 6.7 & 4.5 \\
\hline MNCN FMH'14 3989 & $\mathrm{P} 1 / \mathrm{lt}$ & 7.2 & 4.9 \\
\hline MNCN FMH'14 3615 & $\mathrm{P} 2 / \mathrm{lt}$ & 13.0 & 10.5 \\
\hline MNCN FMH'14 3617 & $\mathrm{P} 3 / \mathrm{lt}$ & 16.0 & 13.7 \\
\hline MNCN FMH'14 3570 & $\mathrm{P} 3 / \mathrm{rt}$ & 16.6 & 14.0 \\
\hline MNCN FMH'14 3615 & $\mathrm{P} 4 / \mathrm{lt}$ & 13.5 & 16.0 \\
\hline MNCN FMH'14 3569 & $\mathrm{P} 4 / \mathrm{rt}$ & 13.5 & 15.9 \\
\hline MNCN FMH'14 1617 & M1/ lt & 18.5 & 16.6 \\
\hline MNCN FMH'14 2932 & $\mathrm{M} 1 / \mathrm{lt}$ & 17.0 & 16.4 \\
\hline MNCN FMH'14 3202 & $\mathrm{M} 1 / \mathrm{lt}$ & 17.2 & 15.6 \\
\hline MNCN FMH'14 690 & $\mathrm{M} 1 / \mathrm{lt}$ & 17.7 & 16.0 \\
\hline MNCN FMH'14 2932 & $\mathrm{M} 1 / \mathrm{rt}$ & 17.1 & 16.1 \\
\hline MNCN FMH'14 3348 & $\mathrm{M} 1 / \mathrm{rt}$ & 18.0 & 16.3 \\
\hline MNCN FMH'14 4195 & $\mathrm{M} 1 / \mathrm{rt}$ & 17.1 & 14.2 \\
\hline MNCN FMH'14 2932 & $\mathrm{M} 2 / \mathrm{lt}$ & 19.7 & 19.3 \\
\hline MNCN FMH'14 2932 & $\mathrm{M} 2 / \mathrm{rt}$ & 20.2 & 19.2 \\
\hline MNCN FMH'14 3762 & $\mathrm{M} 2 / \mathrm{rt}$ & 20.3 & 18.7 \\
\hline MNCN FMH'14 4890 & $\mathrm{M} 2 / \mathrm{rt}$ & 20.0 & 19.5 \\
\hline MNCN FMH'14 4081 & $\mathrm{M} 2 / \mathrm{lt}$ & 20.2 & 18.0 \\
\hline MNCN FMH'14 4236 & $\mathrm{M} 3 / \mathrm{lt}$ & 26.0 & 20,5 \\
\hline MNCN FMH'14 2932 & $\mathrm{M} 3 / \mathrm{lt}$ & 26.5 & 20.5 \\
\hline
\end{tabular}




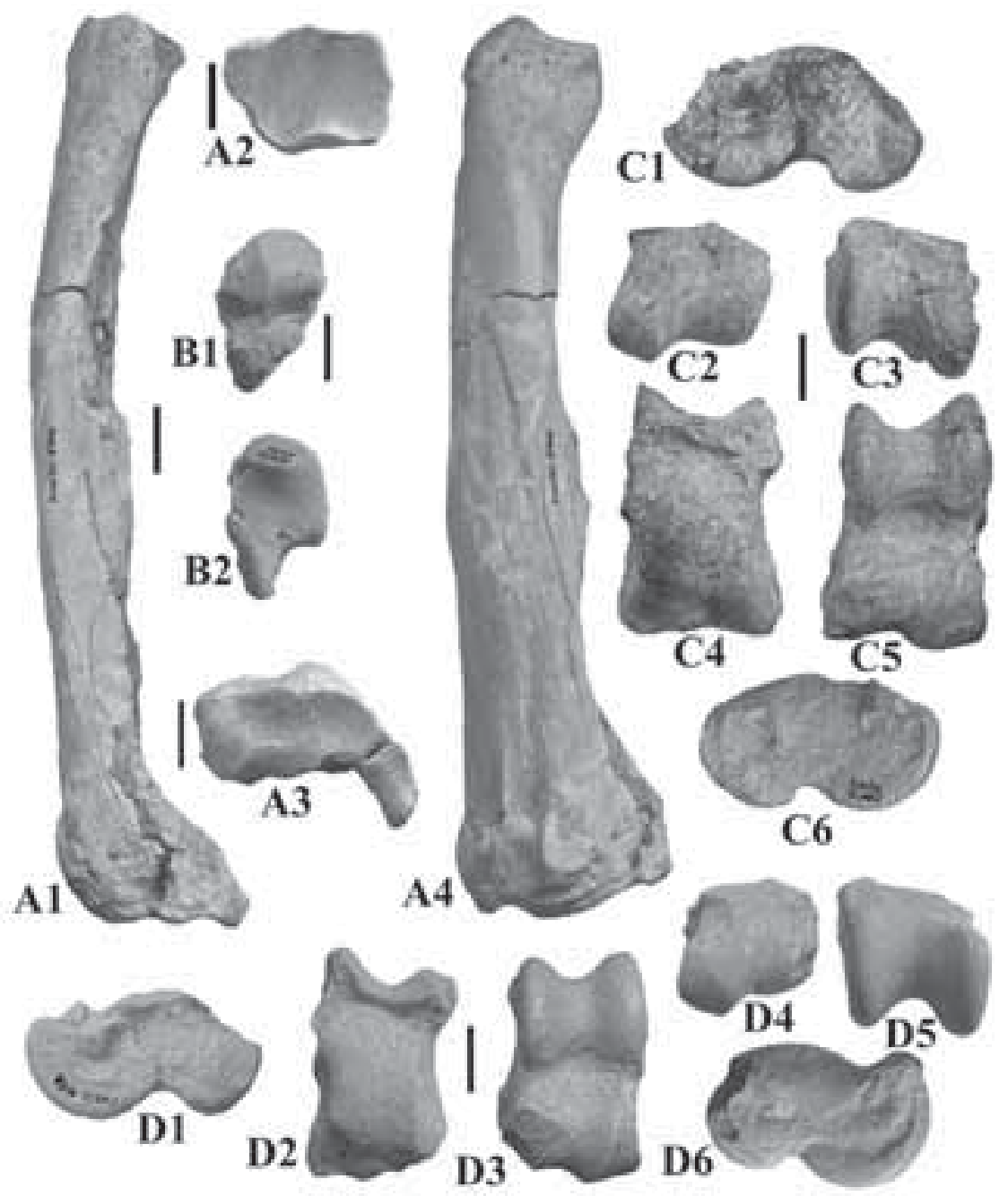

Figure 17. Post-cranial bones from Mahou, Madrid (Spain), attributed to Listriodon retamaensis. a) 2741 , right radius in lateral (A1), proximal (A2), distal (A3), and cranial (A4) views. b) 2793 , unciform in proximal (B1), and distal (B2) views. c) 3247 , left talus in medial $(\mathrm{C} 1)$, distal (C2), tibial (C3), calcaneal (C4), anterior (C5), and lateral (C6) views. d) 4158 , left talus in medial (D1), calcaneal (D2), anterior (D3), distal (D4), tibial (D5), and lateral (D6) views. Scale bar $=10 \mathrm{~mm}$. radius proximally. Distally, the ulna is still attached to the radius and forms a prominent process to the side of, and somewhat caudally of, the distal radial articulation.

The unciform from Mahou FMH'14 2793) shows an elongated posterior process (Fig. 17) as in other species of Listriodon (Leinders, 1976; Van der Made, 1996)

Two tali from Mahou are typically suid in aspect, with a slight angle between the tibial and cuboid parts in anterior view (Fig. 17). The articular facet for the sustentaculum of the calcaneum is simple and is regularly convex from proximal to distal whereas from medial to lateral its profile is almost flat. There is no sign of a lateral ridge on the sustentacular facet, thereby agreeing with observations made by Leinders (1976) concerning listriodont tali.

Los Nogales. A listriodont mandible from Los Nogales lacks the ascending rami, and is warped, but contains all the permanent teeth save for the left incisors, the right $\mathrm{i} / 3$ and left and right $\mathrm{p} / 1$, which are represented by their alveoli (Figs 18-20). The canines are hypselodont indicating male status. The symphysis is spatulate and extends distally as far as the level of the $p / 2$. The mental foramen is small and positioned beneath the post-canine diastema. The horizontal rami are shallow as in listriodonts in general and the jaws are slender.

The $i / 1$ is low, with a central lingual rib. The $i / 2$ has a large distal scoop, and its apex is in line with that of the $\mathrm{i} / 1$, thereby forming a long cutting edge. It also has a lingual ridge. The $\mathrm{i} / 3$ alveolus is close to that of the $\mathrm{i} / 2$ and the canine.

The canines are scrofic in section and emerge from the jaw almost horizontally. The single alveolus of the $p / 1$ is immediately behind the canine and is separated from the $\mathrm{p} / 2$ by an elongate diastema, ca. $22 \mathrm{~mm}$ long.

The premolars and molars are similar to those in the Mahou sample, so it is not necessary to describe them in detail. The Innenhugel of the $\mathrm{p} / 4$ is as tall as the main buccal cusp. The $\mathrm{m} / 2$ and $\mathrm{m} / 3$ have clear buccal cingula, and there is no accessory cuspid behind the talonid of the $\mathrm{m} / 3$.

$\mathrm{A}$ di/2 in the collection from Los Nogales is of interest, as it shows that this tooth is relatively taller than the permanent $\mathrm{i} / 2$ that replaces it. 


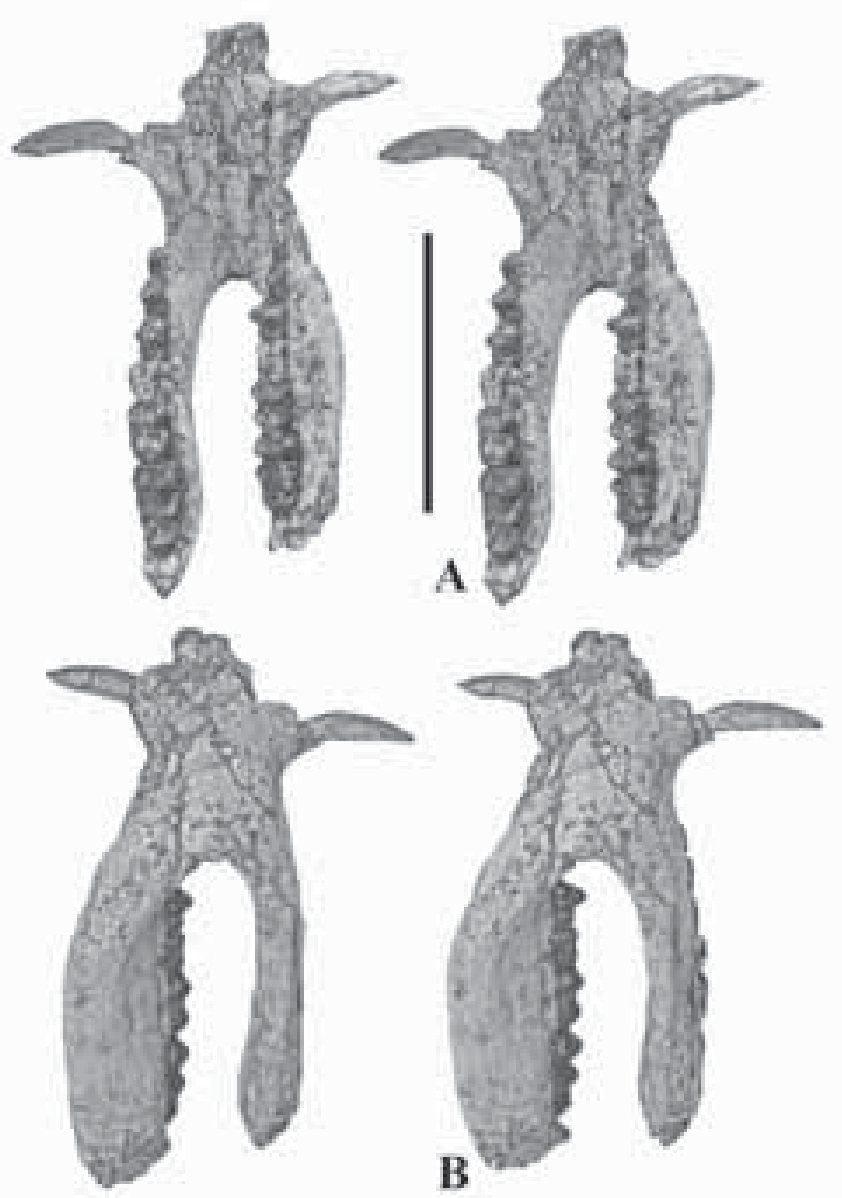

Figure 18. Listriodon retamaensis from Los Nogales, Madrid (Spain). MNCN NG 1001, complete mandible in stereo occlusal view (A), and stereo ventral view (B). Scale bar $=10 \mathrm{~mm}$.

Upper left and right male canines from Los Nogales are interesting as they show a combination of wear processes. There is a prominent wear facet, which cuts a deep notch into the anterior side of the tooth, caused by abrasion against the lower canine. The floor of this wedge-shaped notch is flat, deep near the gingival margin, shallowing laterally. From the point where the notch ends, abrasion is of a different nature, polishing the mesial and ventral aspects of the tooth and blunting the apex. There are numerous shallow scratches on this part of the tooth, many of them at right angles to the long axis of the tooth, with more anteriorly than posteriorly. This style of wear resembles that occurring in extant wart hogs, in which abrasion is caused by repeated passage of vegetation over the surface of the tooth, not only when the animal is feeding, but also when it is moving through grass and bushes.

The unworn D4/ from Los Nogales (NG 1005, Fig. 22d) shows clear zygodont crests on the buccal cusps.

There are two permanent upper fourth premolars from Los Nogales (Fig. 22). One has a single buccal cusp; the
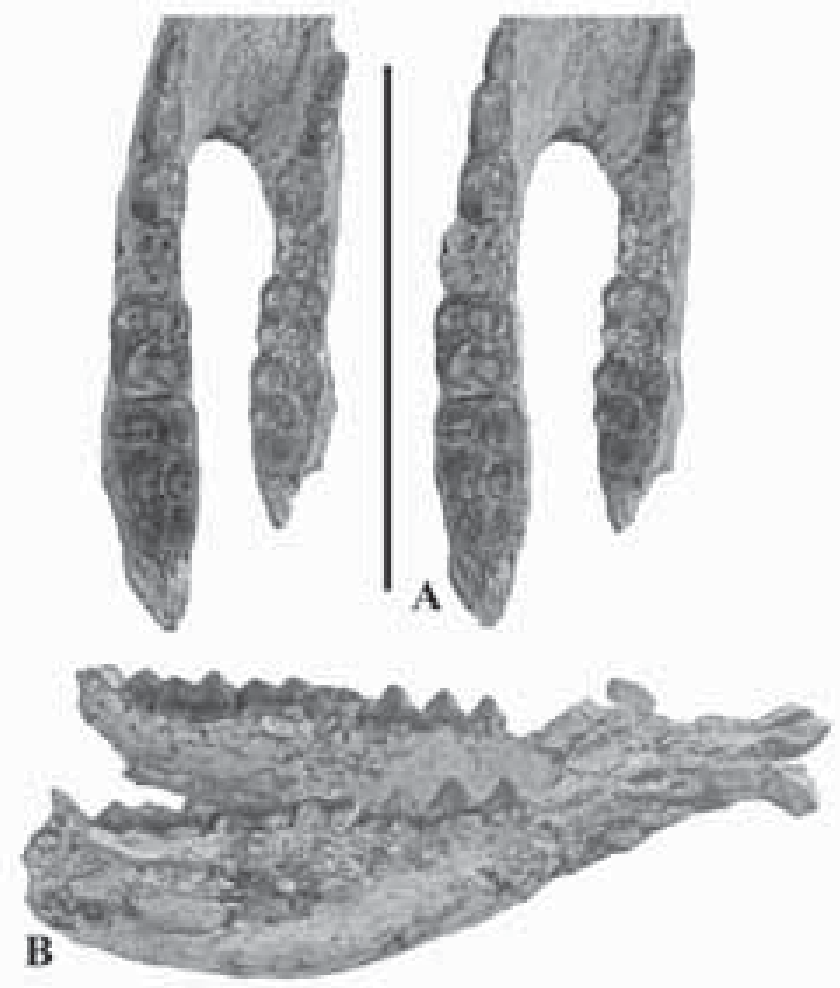

Figure 19. Listriodon retamaensis from Los Nogales, Madrid, Spain. MNCN NG 1001, complete mandible in stereo occlusal view of the cheek teeth (A), right lateral view (B). Scale bar $=10 \mathrm{~mm}$.
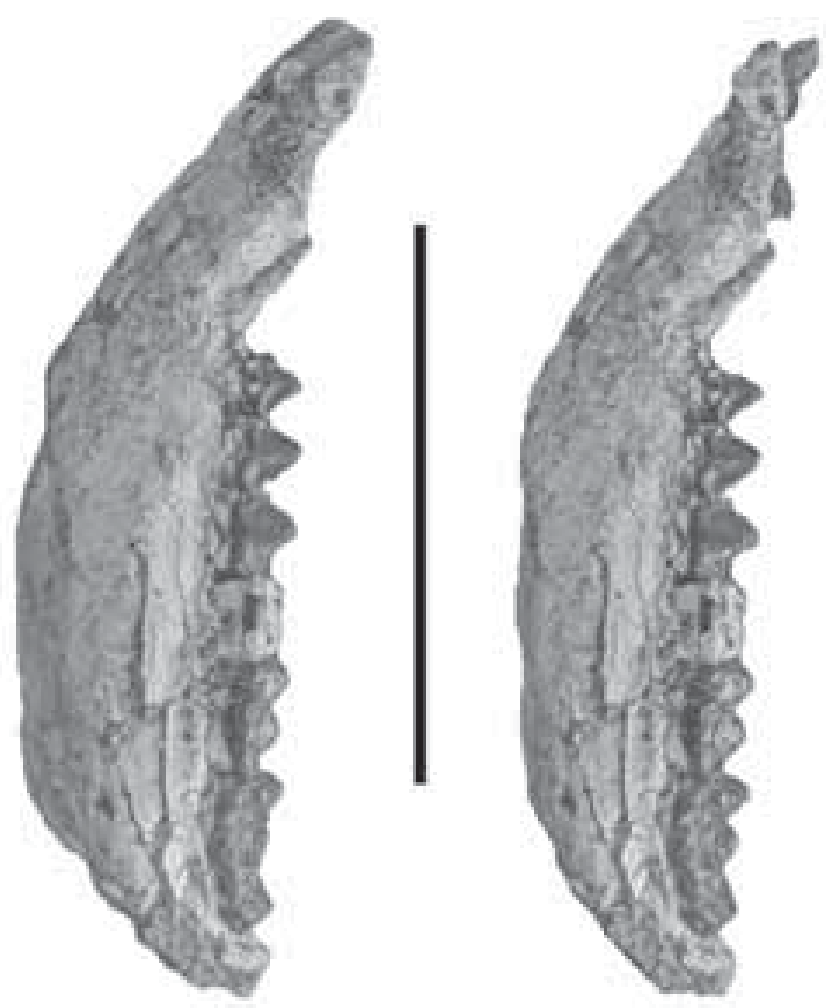

Figure 20. Listriodon retamaensis from Los Nogales, Madrid (Spain). MNCN NG 1001, complete mandible in stereo view of left aspect of jaw. Scale bar $=10 \mathrm{~mm}$. 
other has two as in specimens from Mahou. The D4/, M1/ and M2/ from Los Nogales are like their counterparts from Mahou, and do not need to be described in detail. Like the Mahou sample, the upper molars from Los Nogales have well-formed buccal cingula.

Postcranial bones from Los Nogales. There is an isolated second phalanx from Los Nogales (Fig. 24), which is the right size to belong to Listriodon retamaensis. The shape of the bone is typical of suids.

La Hidroeléctrica. There is a small sample of listriodont teeth from La Hidroeléctrica, which are compatible in dimensions and morphology with the type series of Listriodon retamaensis. The most interesting specimen is an upper male canine of an aged male, in which the wear facet caused by abrasion against the lower canine has become so deep that the apex of the tooth has fallen off, leaving a short stub with $37 \mathrm{~mm}$ of crown exposed mesially and only $28 \mathrm{~mm}$ exposed distally (Fig. 25). The dorsal groove is clearly visible, the ventral one present but subtle. These grooves correspond to the buccal and lingual grooves on the roots of suid canines, but they become dorsal and ventral when the canines flare out sideways. The flat wear facet caused by the lower canine is near the apex of this tooth and the rounded abrasion surface caused by vegetation is present near the gingival level, above all anteriorly. Posteriorly, there is some abrasion caused by vegetation, but it is relatively minor and barely alters the posterior profile of the tooth, whereas abrasion on the anterior aspect of the tooth has greatly modified its surface.

The other interesting canine from La Hidroeléctrica is a deciduous male upper canine in light wear (Fig. 25). It has a much lower crown than the permanent male canines, and its overall shape is reminiscent of hyothere canines and those of female listriodonts, except that the root is open. There is a prominent enamel cap with three "synclines" (Van der Made, 1996) cervically, a broad u-shaped one buccally, a narrower v-shaped one distally and a broad v-shaped one lingually.

There is a well-preserved, lightly worn right $\mathrm{d} / 4$ from La Hidroeléctrica that shows the cusp morphology clearly. The crown is posed on five roots (two lingual ones, three buccal ones) and it follows the usual suid grundplan of three lophids each comprised of two cuspids. There are
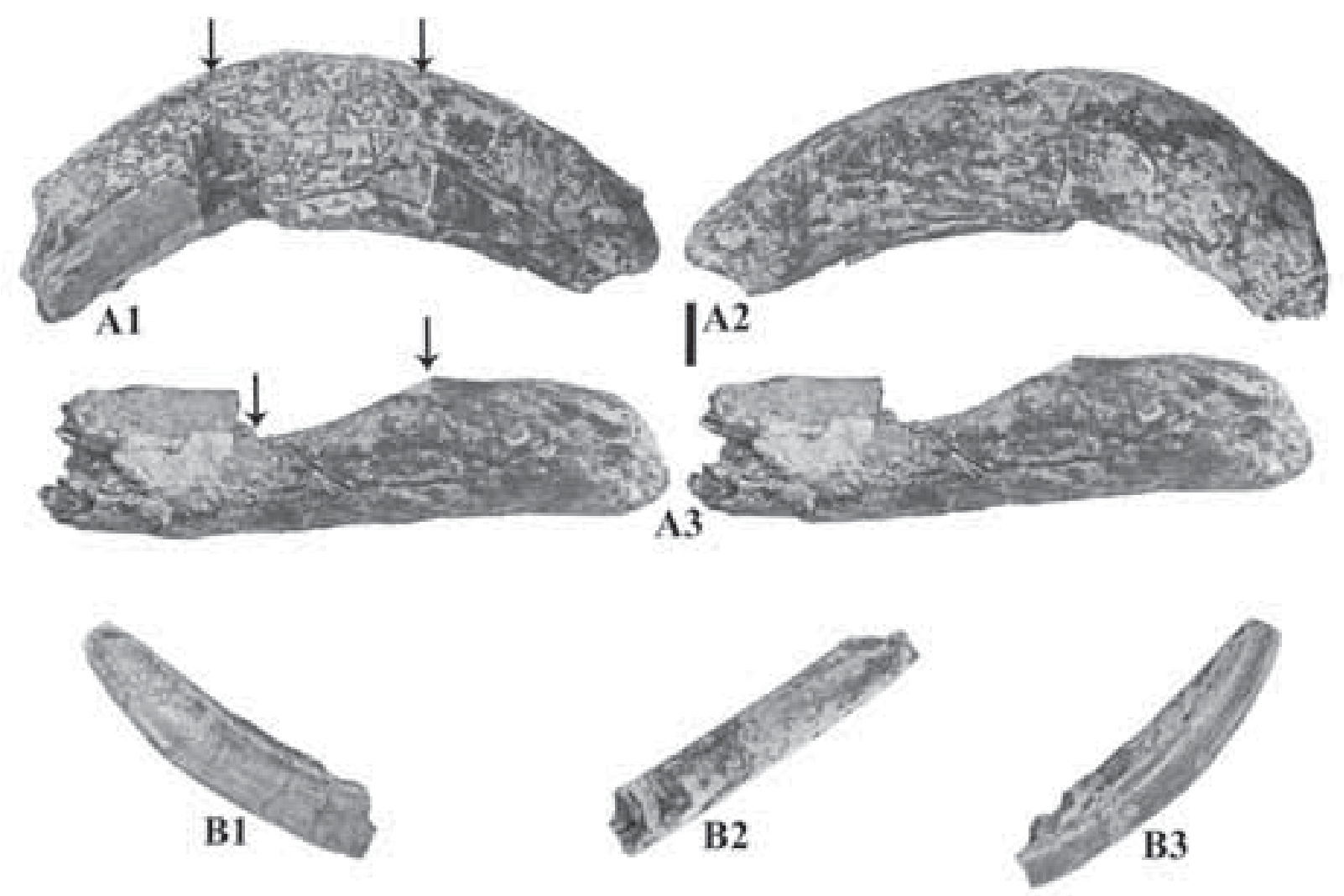

Figure 21. Listriodon retamaensis from Los Nogales, Madrid (Spain). a) NG 1007, right upper canine in anterior (A1), posterior (A2) and stereo dorsal (A3) views. Arrows show the extent of the notch-like wear facet caused by abrasion against the lower canine. b) 1009, right lower canine in lingual (B1), distal (B2), and labial (B3) views. Scale bar $=10 \mathrm{~mm}$. 


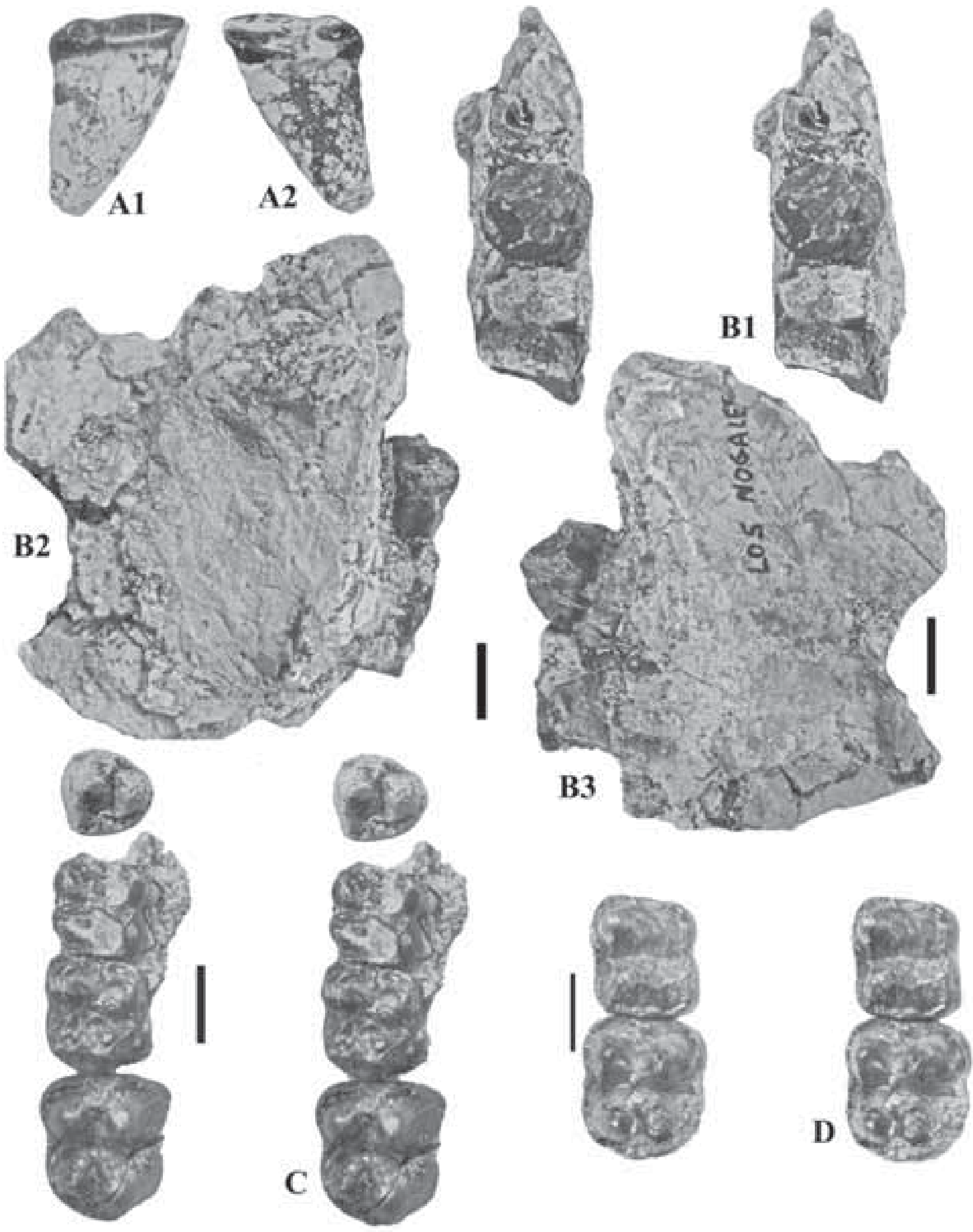

Figure 22. Listriodon retamaensis from Los Nogales, Madrid (Spain). Upper teeth. a) NG 1002, left I1/ in labial (A1), and lingual (A2) views. b) NG 1003, left maxilla fragment containing P4/ and M1/ in stereo occlusal (B1), lingual (B2), and buccal (B3) views. c) NG 1004, right D4/-M2/ and P4/, stereo occlusal view; d) NG 1005, right D4/-M1/, stereo occlusal view. Scale bar $=10 \mathrm{~mm}$. 
Figure 23. Listriodon retamaensis (a) and Retroporcus complutensis $(\mathbf{b}, \mathbf{c})$ from Los Nogales, Madrid (Spain). a) NG 1005, left di/2 in stereo lingual (A1), mesial (A2), and stereo labial (A3) views. b) NG 1012, left I1/ in labial (B1), stereo lingual (B2), and lateral (B3) view. c) NG 1011, right D4/, stereo occlusal view. Scale bar $=10 \mathrm{~mm}$.
Table 3. Measurements (in $\mathrm{mm}$ ) of the teeth of Listriodon retamaensis from Los Nogales, Madrid (Spain). lt: left; rt: right; --: no measurement possible.

\begin{tabular}{|c|c|c|c|}
\hline Catalogue & Tooth & $\begin{array}{l}\text { Mesio-distal } \\
\text { Length }\end{array}$ & $\begin{array}{c}\text { Buc- } \\
\text { co-lingual } \\
\text { Breadth }\end{array}$ \\
\hline MNCN Los Nogales 459 & $\mathrm{di} / 2 \mathrm{lt}$ & 6.4 & 4.9 \\
\hline MNCN Los Nogales & $\mathrm{i} / 1 \mathrm{rt}$ & 9.1 & 6.9 \\
\hline MNCN Los Nogales & $\mathrm{i} / 2 \mathrm{rt}$ & 10.8 & 7.6 \\
\hline MNCN Los Nogales & $\mathrm{c} / \mathrm{m} \mathrm{lt}$ & 10.3 & 9.2 \\
\hline MNCN Los Nogales & $\mathrm{c} / \mathrm{m} \mathrm{rt}$ & 10.4 & 9.2 \\
\hline MNCN Los Nogales 193 & $\mathrm{c} / \mathrm{m} \mathrm{rt}$ & 10.4 & 9.1 \\
\hline MNCN Los Nogales & $\mathrm{p} / 2 \mathrm{lt}$ & 10.9 & 5.5 \\
\hline MNCN Los Nogales & $\mathrm{p} / 2 \mathrm{rt}$ & 11.3 & 5.7 \\
\hline MNCN Los Nogales & $\mathrm{p} / 3 \mathrm{lt}$ & 14.0 & 8.3 \\
\hline MNCN Los Nogales & $\mathrm{p} / 3 \mathrm{rt}$ & 13.6 & 8.5 \\
\hline MNCN Los Nogales & $\mathrm{p} / 4 \mathrm{lt}$ & 15.6 & 11.0 \\
\hline MNCN Los Nogales & $\mathrm{p} / 4 \mathrm{rt}$ & 15.8 & 11.1 \\
\hline MNCN Los Nogales & $\mathrm{m} / 1 \mathrm{lt}$ & -- & 12.0 \\
\hline MNCN Los Nogales & $\mathrm{m} / 1 \mathrm{rt}$ & -- & 12.5 \\
\hline MNCN Los Nogales & $\mathrm{m} / 2 \mathrm{lt}$ & 21.2 & 15.6 \\
\hline MNCN Los Nogales & $\mathrm{m} / 2 \mathrm{rt}$ & 20.0 & 15.5 \\
\hline MNCN Los Nogales & $\mathrm{m} / 3 \mathrm{lt}$ & 31.0 & 18.0 \\
\hline MNCN Los Nogales & $\mathrm{m} / 3 \mathrm{rt}$ & 31.5 & 18.1 \\
\hline MNCN Los Nogales 408 & $\mathrm{D} 4 / \mathrm{rt}$ & 14.5 & 13.2 \\
\hline MNCN Los Nogales 104 & $\mathrm{D} 4 / \mathrm{rt}$ & 14.7 & 14.4 \\
\hline MNCN Los Nogales 348 & $\mathrm{I} 1 / \mathrm{lt}$ & 16.3 & 8.2 \\
\hline MNCN Los Nogales 193 & $\mathrm{CM} / \mathrm{lt}$ & 25.5 & 27.0 \\
\hline MNCN Los Nogales 33 & $\mathrm{CM} / \mathrm{rt}$ & 27.0 & 28.0 \\
\hline MNCN Los Nogales & $\mathrm{P} 4 / \mathrm{lt}$ & 14.1 & 16.2 \\
\hline MNCN Los Nogales & M1/ lt & -- & 16.9 \\
\hline MNCN Los Nogales 104 & $\mathrm{M} 1 / \mathrm{rt}$ & 17.0 & 16.2 \\
\hline MNCN Los Nogales 408 & $\mathrm{M} 1 / \mathrm{rt}$ & 17.7 & 15.8 \\
\hline MNCN Los Nogales 104 & $\mathrm{M} 2 / \mathrm{rt}$ & 22.0 & 19.5 \\
\hline
\end{tabular}

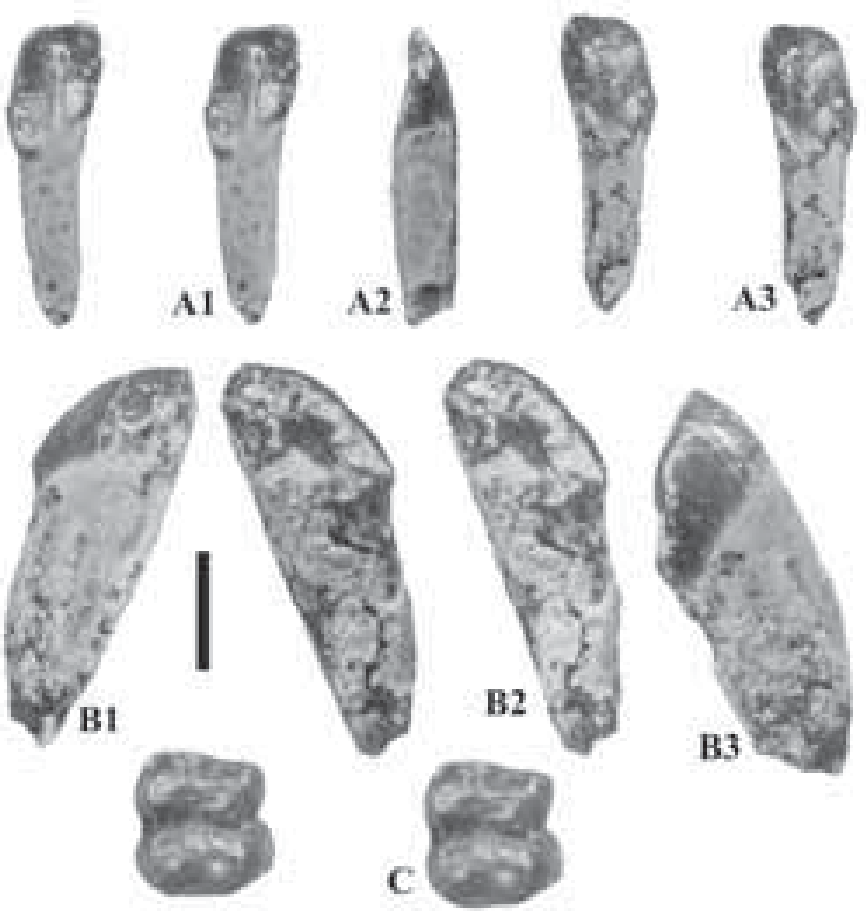

accessory cusplets in the midline of the crown in each of the transverse valleys as in the permanent molars, which are joined by cristids from the buccal main cusps. The hindmost lophid shows cristids running towards each other from the apices of the entoconid and hypoconid thereby imparting a sublophodont aspect to the lophid, which is nevertherless still somewhat bunodont.

Barajas. The Barajas listriodont sample is important because it is the only one which preserves the ascending rami of the mandible (Figs 28-30). The coronoid process in the jaw (MNCN 74607, BAR 62) is steep anteriorly and in lateral view it hides the distal part of the $\mathrm{m} / 3$. The mandibular condyle is high above the occlusal surface of the cheek teeth. There is a clear angle in the ventral margin of the ramus slightly behind the level of the $\mathrm{m} / 3$ descending a short way before curving backwards and then upwards towards the condyle. This individual is a male as shown by the hypselodont lower canine preserved in the left ramus. The symphysis is spatulate in ventral view, and the canine emerges at a low angle sweeping laterally and pointing backwards at its apex. The wear facet is on the distal side of the canine but only at the apex, the base of the tooth remaining unworn for a distance of $26 \mathrm{~mm}$ from the alveolar margin. The section of the canine is slightly scrofic (lingual length $-15.5 \mathrm{~mm}$, buccal length $-12.5 \mathrm{~mm}$, distal breadth $-13 \mathrm{~mm}$ ). This distal surface of the tooth is enamel free. In lateral view the mandible is shallow. The symphysis extends backwards as far as the level of the middle of $\mathrm{p} / 2$. The diastema between 

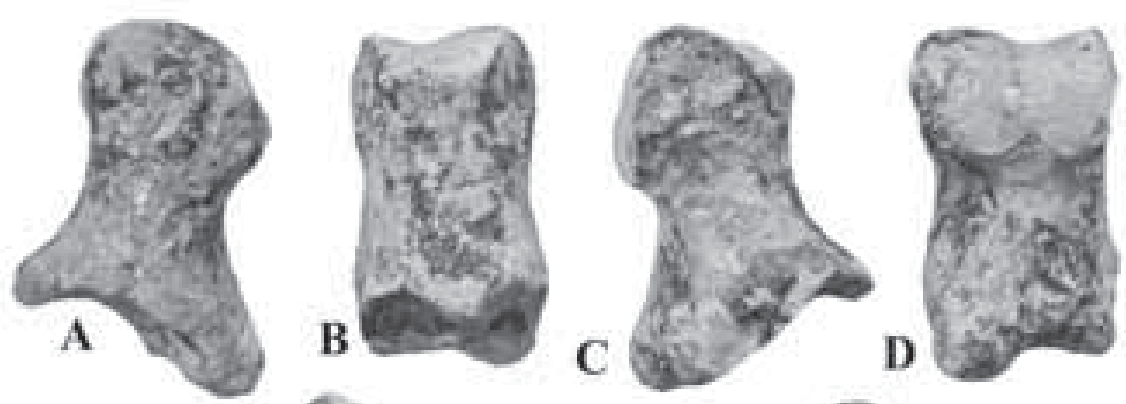

E
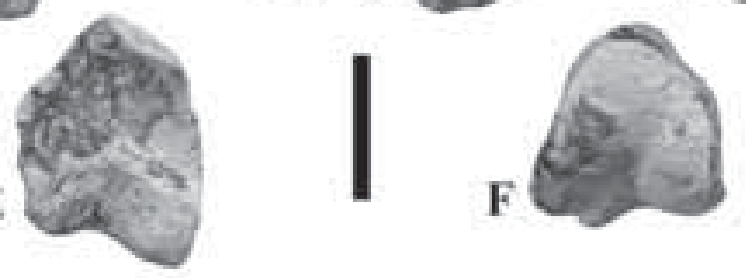

Figure 24. MNCN NG 1010, 2nd phalanx from Los Nogales, Madrid (Spain) attributed to Listriodon retamaensis in axial $(\mathrm{A})$, dorsal (B), abaxial (C), volar (D), proximal (E), and distal (F) views. Scale bar $=10 \mathrm{~mm}$.
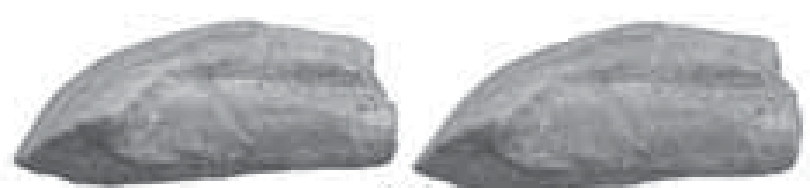

A1
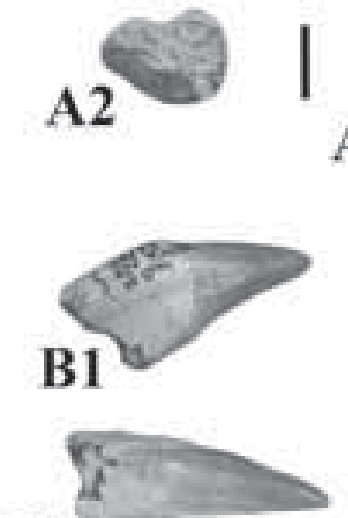

B3

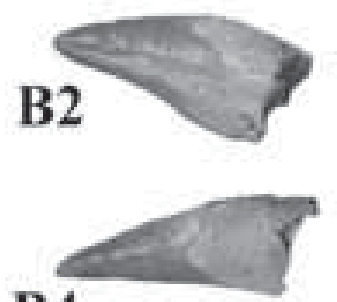

B4

Figure 25. Listriodon retamaensis from La Hidroeléctrica, Madrid (Spain). a) HOT-SI-072, left upper male canine in stereo dorsal view (A1), section at root end of tooth (A2), and anterior (A3) view. b) HOTSI-N044, deciduous right male canine in dorsal (B1), ventral (B2), posterior (B3), and anterior (B4) views. Scale bar $=10 \mathrm{~mm}$.
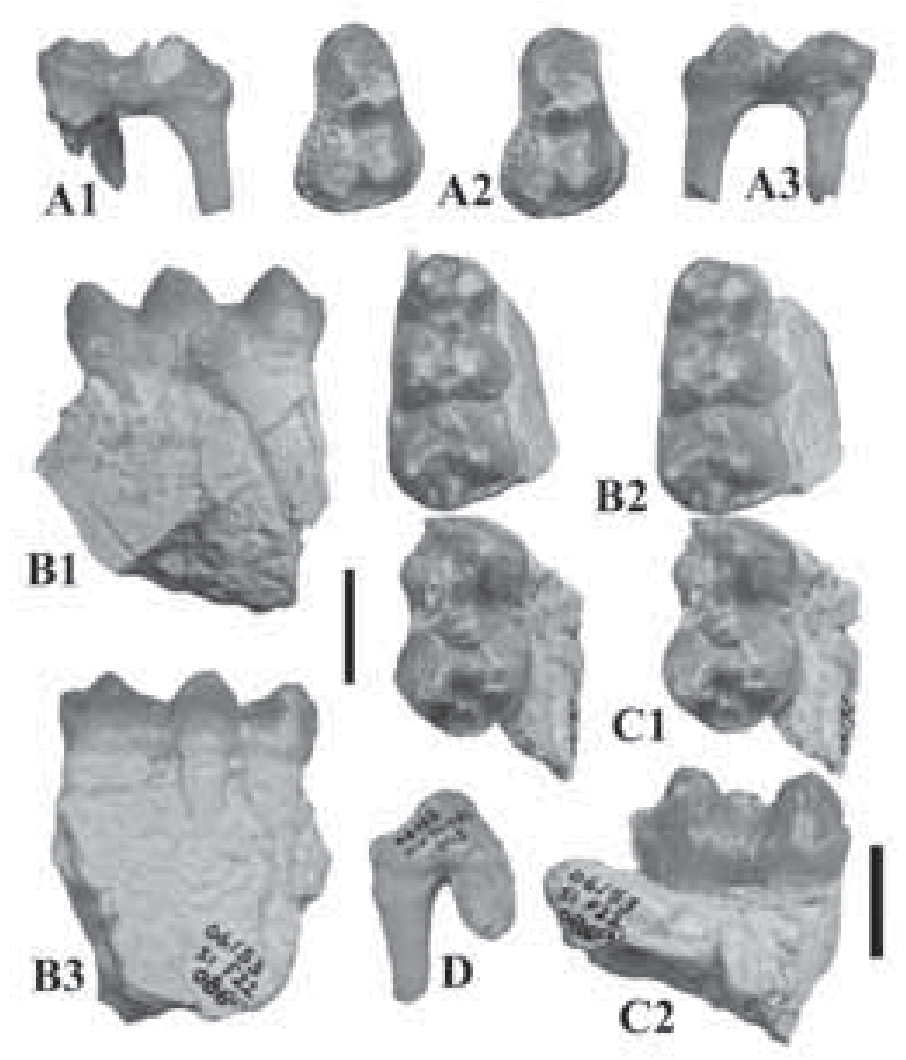

Figure 26. Listriodon retamaensis from La Hidroeléctrica, Madrid (Spain). Deciduous and permanent teeth. a) HOTSI-020, left D3/ in buccal (A1), stereo occlusal (A2), and lingual (A3) views. b) HOT-SI F22, right mandible fragment containing $\mathrm{d} / 4$ in lingual (B1), stereo occlusal (B2), and buccal (B3) views. c) HOT SI F22, right $\mathrm{m} / 1$ in stereo occlusal (C1) view, and buccal view (C2). d) HOT SI 043, left D2/, buccal view. Scale bar $=10 \mathrm{~mm}$. 

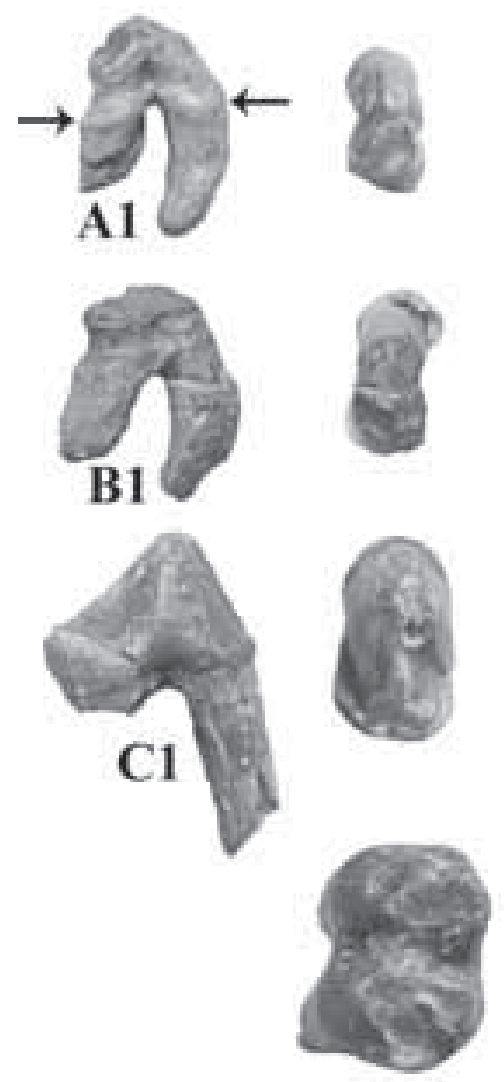
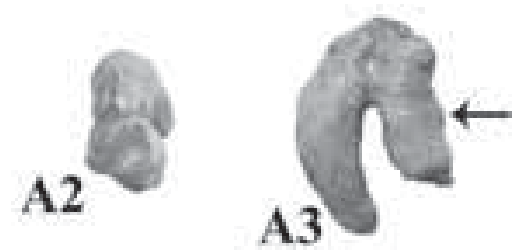

B2
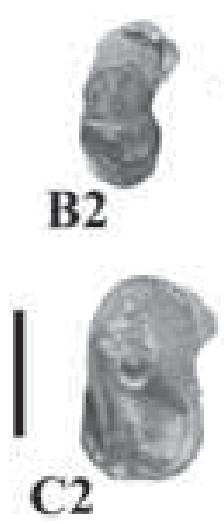

B3
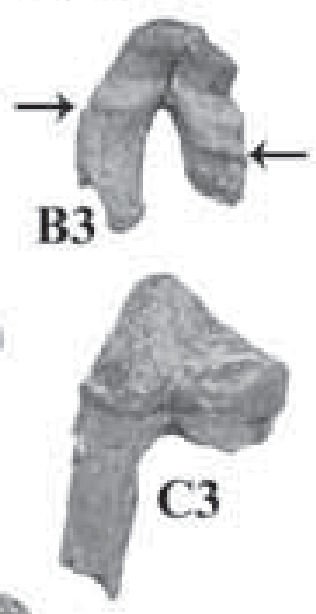

Figure 27. Listriodon retamaensis from $\mathrm{La}$ Hidroeléctrica, Madrid (Spain). Permanent teeth. a) HOT-SI $\mathrm{H}-1400$, right $\mathrm{P} 1 /$ in buccal (A1), stereo occlusal (A2), and lingual (A3) views. b) HOT-SI H-14 004, left P1/ in buccal (B1), stereo occlusal (B2), and lingual (B3) views; (arrows show the gingival levels in the anterior premolars). c) HOT-SI M5 127, left $\mathrm{p} / 3$ in lingual (C1), stereo occlusal (C2), and buccal (C3) views. d) HOT-SI 06, left $\mathrm{m} / 1$, stereo occlusal view. Scale bar $=$ $10 \mathrm{~mm}$

Table 4. Measurements (in $\mathrm{mm}$ ) of the teeth of Listriodon retamaensis from La Hidroeléctrica, Madrid (Spain). lt: left; rt: right; --: no measurement possible.

\begin{tabular}{llcc}
\hline Catalogue & Tooth & $\begin{array}{c}\text { Mesio-distal } \\
\text { Length }\end{array}$ & $\begin{array}{c}\text { Bucco-lingual } \\
\text { Breadth }\end{array}$ \\
\hline MNCN HOT-SI F22 06/53 & $\mathrm{d} / 4 \mathrm{rt}$ & 21.5 & 11.0 \\
MNCN HOT-SI F22 06/53 & $\mathrm{i} / 1 \mathrm{lt}$ & 9.2 & -- \\
MNCN HOT-SI M5 127 & $\mathrm{p} / 3 \mathrm{lt}$ & 15.8 & 9.2 \\
MNCN HOT-SI 06 & $\mathrm{m} / 1 \mathrm{lt}$ & 18.7 & 14.1 \\
MNCN HOT-SI F22 06/53 & $\mathrm{m} / 1 \mathrm{rt}$ & 19.5 & 12.5 \\
MNCN HOT-SI F22 06/53 & $\mathrm{dCM} / \mathrm{rt}$ & 14.9 & 11.3 \\
MNCN HOT-SI F22 06/53 & $\mathrm{D} 2 / \mathrm{lt}$ & 12.7 & -- \\
MNCN HOT-SI F22 06/53 & $\mathrm{D} 3 / \mathrm{lt}$ & 15.7 & 11.2 \\
MNCN HOT-SI 06 & $\mathrm{CM} / \mathrm{lt}$ & -- & 17.0 \\
MNCN HOT-SI 072 & $\mathrm{CM} / \mathrm{lt}$ & 24.0 & 18.0 \\
MNCN HOT-SI H-14 001 & $\mathrm{P} 1 / \mathrm{rt}$ & 9.8 & 5.6 \\
MNCN HOT-SI H-14 004 & $\mathrm{P} 1 / \mathrm{lt}$ & 10.0 & 5.7 \\
MNCN HOT-SI M5-150 & $\mathrm{P} 2 / \mathrm{lt}$ & 13.3 & -- \\
MNCN HOT-SI H-13T & $\mathrm{P} 4 / \mathrm{lt}$ & 13.9 & 15.6 \\
MNCN HOT-SI H-14 & $\mathrm{P} 4 / \mathrm{rt}$ & -- & 15.2 \\
\hline
\end{tabular}

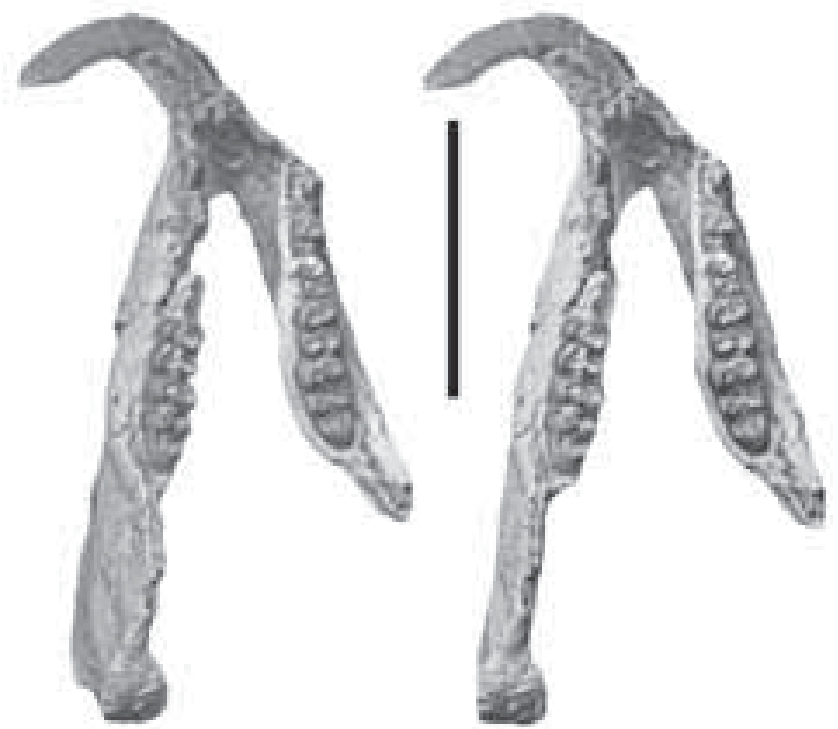

Figure 28. Listriodon retamaensis from Barajas (Spain). MNCN 74603, almost complete mandible. Stereo occlusal view. Scale bar $=10 \mathrm{~mm}$. 

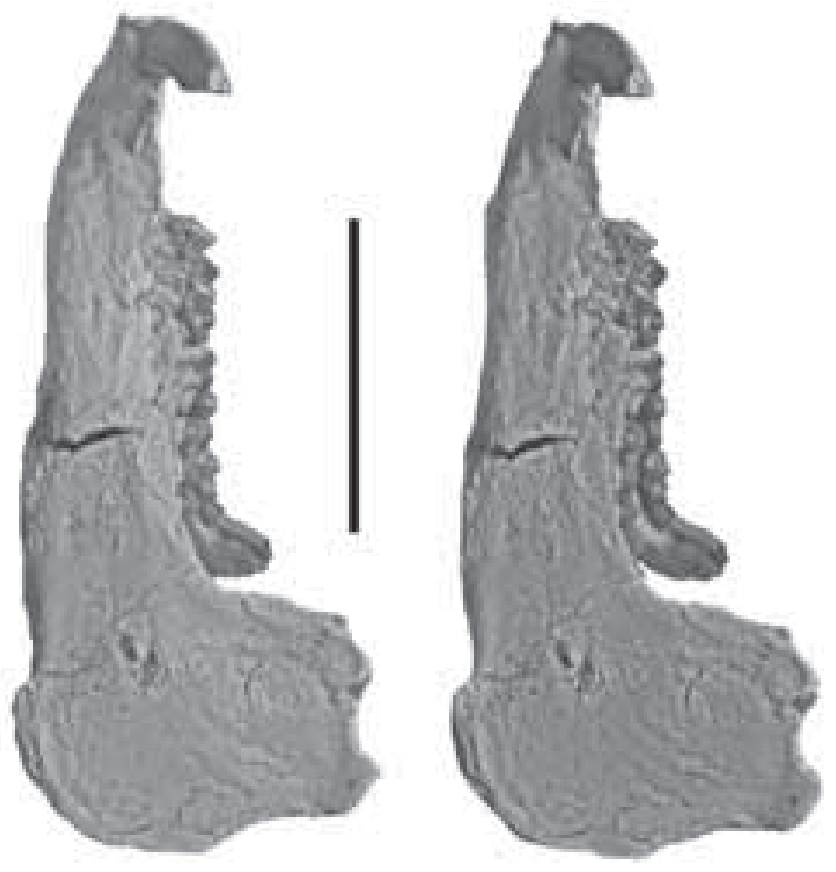

Figure 29. Listriodon retamaensis from Barajas (Spain). MNCN 74603, almost complete mandible. Stereo left lateral view. Scale bar $=10 \mathrm{~mm}$.

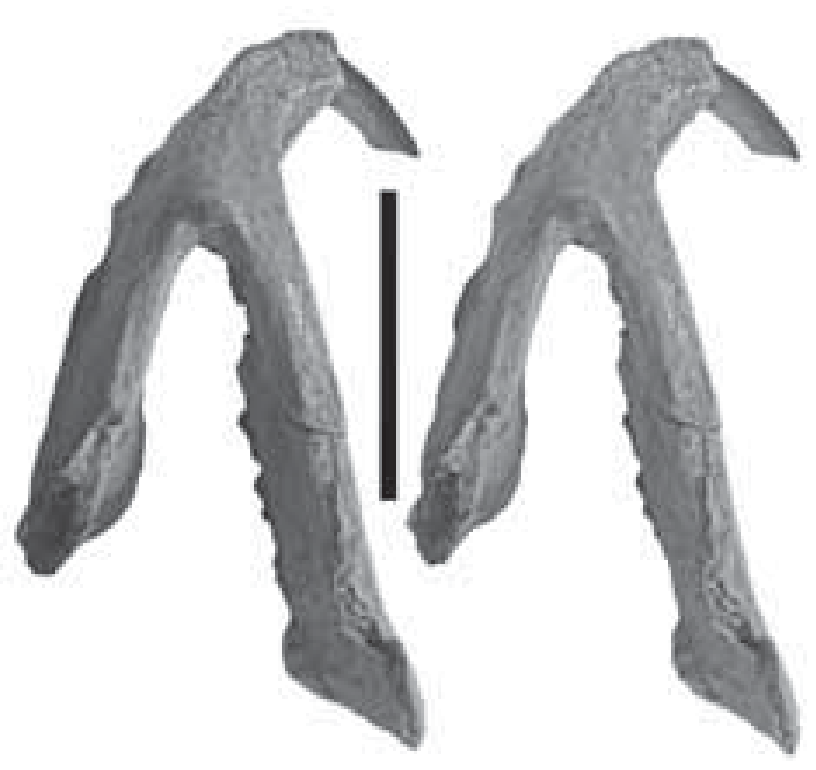

Figure 30. Listriodon retamaensis from Barajas (Spain). MNCN 74603, almost complete mandible. Stereo ventral view. Scale bar $=10 \mathrm{~mm}$.
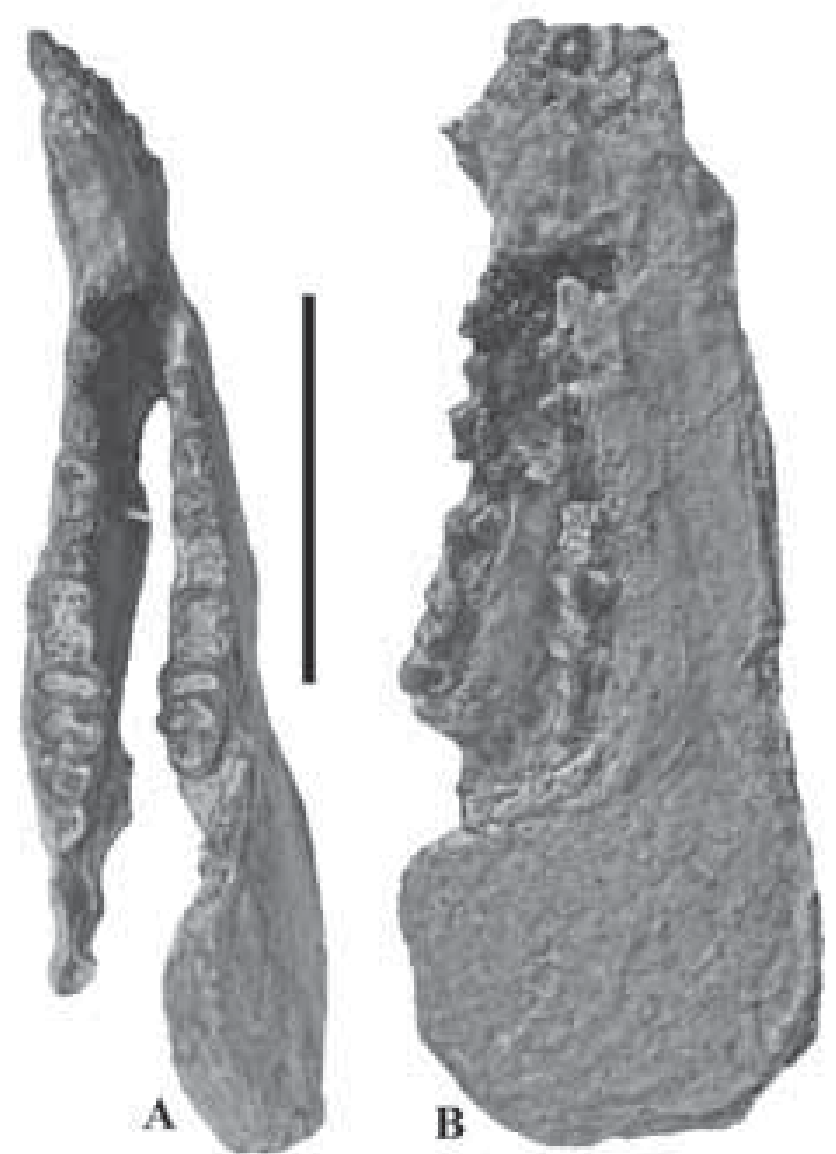

Figure 31. Listriodon retamaensis from Barajas (Spain). MNCN 74607, crushed but complete mandible. Stereo slightly oblique occlusal view. Scale bar $=10 \mathrm{~mm}$. 

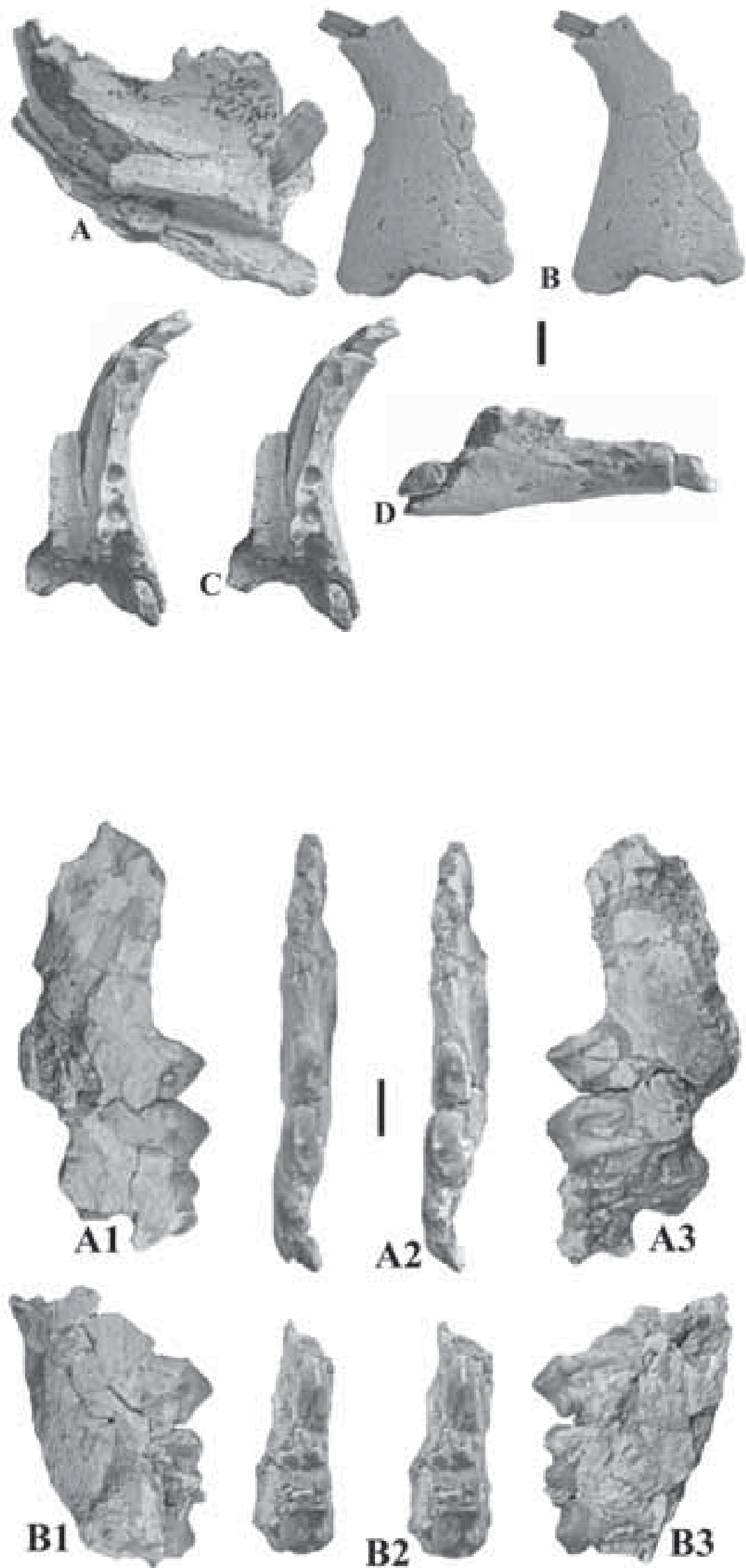
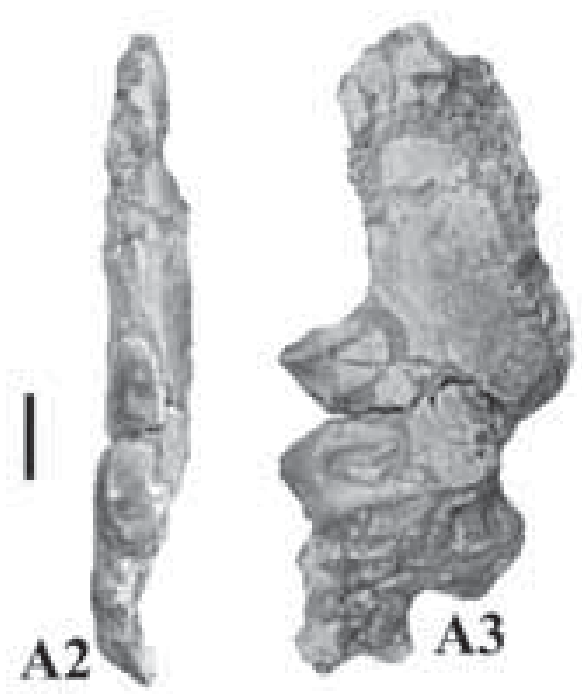

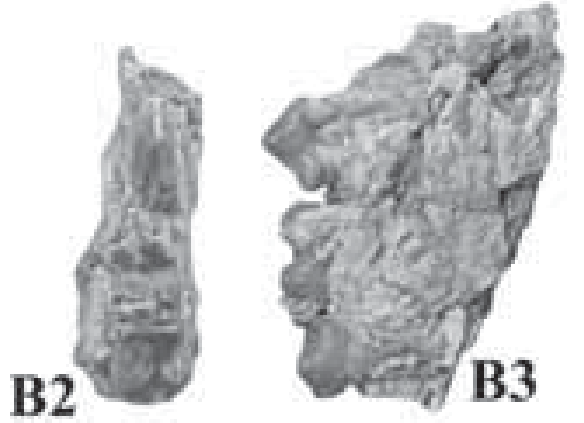

Figure 32. Listriodon retamaensis from Barajas (Spain). MNCN 74600, mandibular symphysis with male canine, diastema and alveoli of $\mathrm{p} / 2$ and $\mathrm{p} / 3$ in lingual view (A), stereo ventral view (B), stereo occlusal view (C), and lateral view (D). Scale bar $=10 \mathrm{~mm}$.
Figure 33. Listriodon retamaensis from Barajas (Spain). Deciduous teeth. a) MNCN 74601 left mandible with $d / 2, d / 3$ and fragment of $d / 4$ in buccal (A1), stereo occlusal (A2), and lingual (A3) views. b) MNCN 74606, left mandible with $\mathrm{d} / 3-\mathrm{d} / 4$ in buccal (B1), stereo occlusal (B2), and lingual (B3) views. Scale bar $=10 \mathrm{~mm}$. 


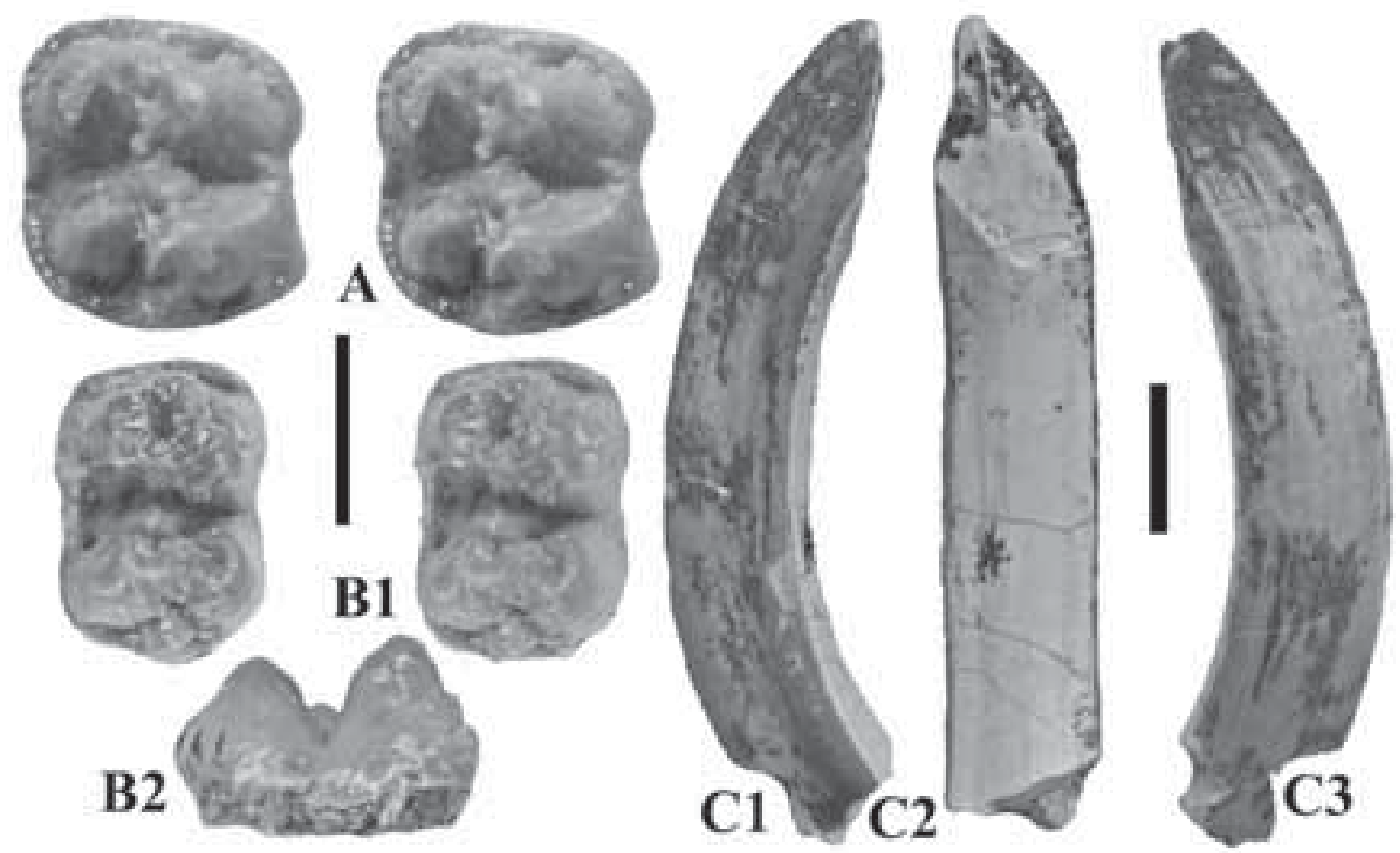

Figure 34. Listriodon retamaensis from Barajas (Spain). Isolated teeth. a) MNCN 74605, right M1/, stereo occlusal view. b) MNCN 74609, left $\mathrm{m} / 1$ in stereo occlusal view (B1), and lingual view (B2). c) MNCN 74602, left lower male canine in labial (C1), distal (C2), and lingual (C3) views. Scale bars $=10 \mathrm{~mm}$.
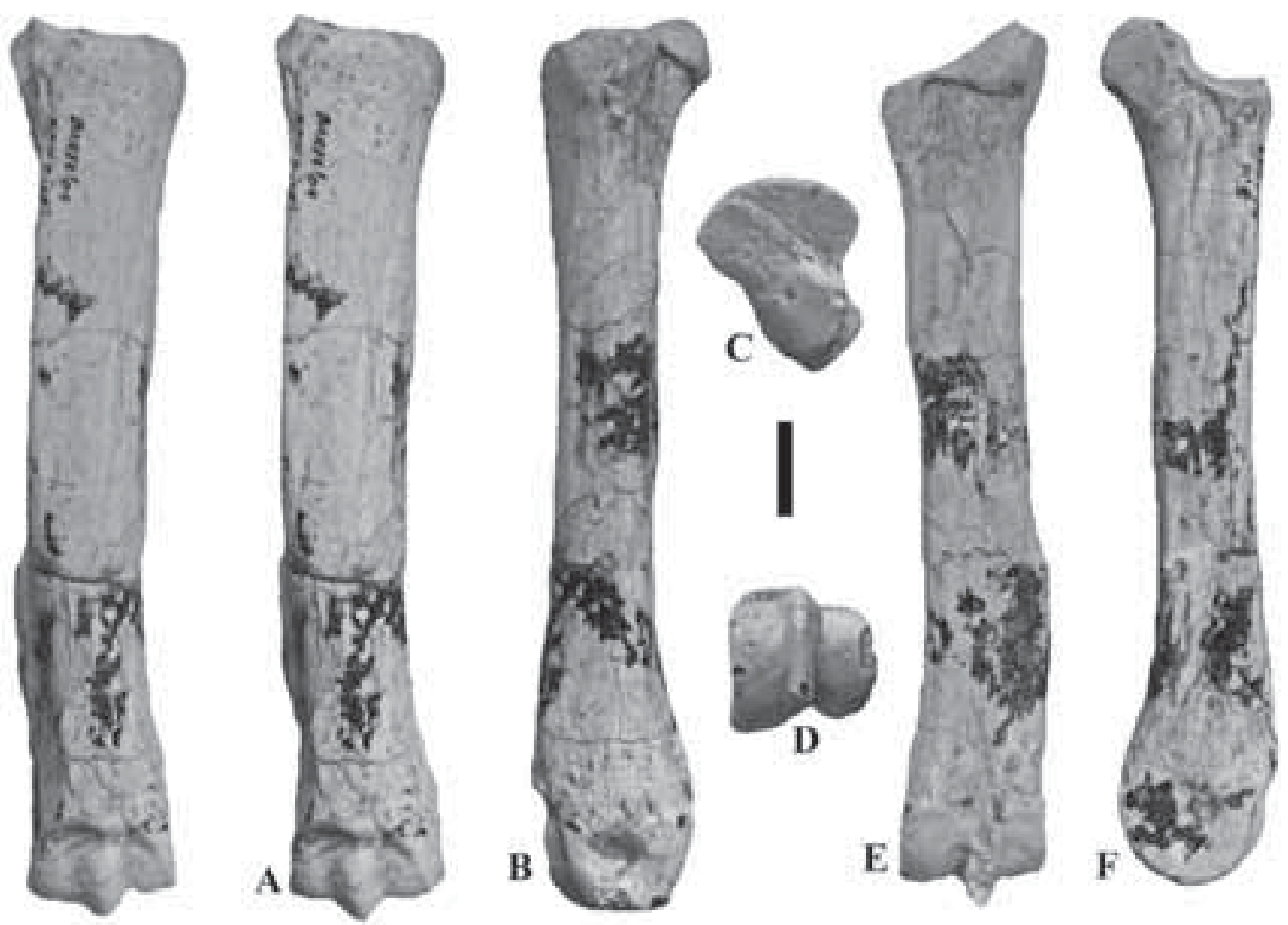

Figure 35. Listriodon retamaensis from Barajas (Spain). MNCN 74610, left IVth metacarpal in stereo dorsal (A), lateral (B), proximal (C), distal (D), volar (E), and axial (F) views. Scale bar $=10 \mathrm{~mm}$. 
the canine and the $\mathrm{p} / 2$ is $39 \mathrm{~mm}$ long. The lower molars show the usual buccal cingulum and bunolophodont cusp morphology that occurs in Listriodon retamaensis.

A second almost complete mandible from Barajas is of a senile individual in which the $\mathrm{m} / 3 \mathrm{~s}$ are deeply worn and the $\mathrm{m} / 1 \mathrm{~s}$ almost eradicated by wear (Fig. 31 ). The canine section suggests that the individual was a male. The incisor battery shows a straight cutting edge running from $\mathrm{i} / 1-\mathrm{i} / 2$,

Table 5. Measurements (in $\mathrm{mm}$ ) of the teeth of Listriodon retamaensis from Barajas, Madrid (Spain). c/m: male lower canine; lt: left; rt: right; --: no measurement possible.

\begin{tabular}{|c|c|c|c|}
\hline Catalogue & Tooth & $\begin{array}{l}\text { Mesio-distal } \\
\text { Length }\end{array}$ & $\begin{array}{l}\text { Bucco-lingual } \\
\text { Breadth }\end{array}$ \\
\hline MNCN 74601 & $\mathrm{~d} / 2 \mathrm{lt}$ & 10.1 & 5.4 \\
\hline MNCN 74601 & $\mathrm{~d} / 3 \mathrm{lt}$ & 13.2 & 6.8 \\
\hline MNCN 74606 & $\mathrm{~d} / 3 \mathrm{lt}$ & 12.6 & 6.3 \\
\hline MNCN 74606 & $\mathrm{~d} / 4 \mathrm{lt}$ & 24.0 & 10.6 \\
\hline MNCN 74607 & $\mathrm{i} / 1 \mathrm{lt}$ & 9.3 & 6.5 \\
\hline MNCN 74607 & $\mathrm{i} / 1 \mathrm{rt}$ & 8.0 & 6.3 \\
\hline MNCN 74607 & $\mathrm{i} / 2 \mathrm{lt}$ & 11.0 & 8.0 \\
\hline MNCN 74607 & $\mathrm{i} / 2 \mathrm{rt}$ & 10.2 & -- \\
\hline MNCN 74608 & $\mathrm{i} / 3 \mathrm{rt}$ & -- & 7.0 \\
\hline MNCN 74603 & $\mathrm{c} / \mathrm{m} \mathrm{lt}$ & 15.0 & 13.7 \\
\hline MNCN 74607 & $\mathrm{c} / \mathrm{m} \mathrm{lt}$ & 11.5 & 8.0 \\
\hline MNCN 74603 & $\mathrm{p} / 2 \mathrm{lt}$ & 15.0 & 9.3 \\
\hline MNCN 74602 & $\mathrm{c} / \mathrm{m} \mathrm{lt}$ & 11.2 & 10.2 \\
\hline MNCN 74600 & $\mathrm{c} / \mathrm{m} \mathrm{rt}$ & 13.0 & 7.0 \\
\hline MNCN 74607 & $\mathrm{p} / 2 \mathrm{lt}$ & 11.0 & 6.5 \\
\hline MNCN 74607 & $\mathrm{p} / 2 \mathrm{rt}$ & 12.1 & 6.5 \\
\hline MNCN 74603 & $\mathrm{p} / 3 \mathrm{lt}$ & 18.6 & 11.7 \\
\hline MNCN 74607 & $\mathrm{p} / 3 \mathrm{lt}$ & 13.3 & 9.4 \\
\hline MNCN 74603 & $\mathrm{p} / 3 \mathrm{rt}$ & 17.6 & -- \\
\hline MNCN 74607 & $\mathrm{p} / 3 \mathrm{rt}$ & 13.3 & 9.3 \\
\hline MNCN 74607 & $\mathrm{p} / 4 \mathrm{lt}$ & 15.7 & 11.4 \\
\hline MNCN 74603 & $\mathrm{p} / 4 \mathrm{rt}$ & 17.7 & 14.0 \\
\hline MNCN 74607 & $\mathrm{p} / 4 \mathrm{rt}$ & 15.2 & 11.5 \\
\hline MNCN 74604 & $\mathrm{p} / 4 \mathrm{rt}$ & 18.3 & 11.9 \\
\hline MNCN 74607 & $\mathrm{~m} / 2 \mathrm{lt}$ & 20.0 & 16.5 \\
\hline MNCN 74603 & $\mathrm{~m} / 2 \mathrm{rt}$ & 23.3 & 18.8 \\
\hline MNCN 74607 & $\mathrm{~m} / 2 \mathrm{rt}$ & 19.1 & 16.9 \\
\hline MNCN 74604 & $\mathrm{~m} / 2 \mathrm{lt}$ & 23.0 & 18.4 \\
\hline MNCN 74604 & $\mathrm{~m} / 2 \mathrm{rt}$ & 22.2 & 17.0 \\
\hline MNCN 74607 & $\mathrm{~m} / 3 \mathrm{lt}$ & 31.8 & 18.0 \\
\hline MNCN 74603 & $\mathrm{~m} / 3 \mathrm{rt}$ & 35.0 & 21.0 \\
\hline MNCN 74607 & $\mathrm{~m} / 3 \mathrm{rt}$ & 31.6 & 18.0 \\
\hline MNCN 74609 & $\mathrm{~m} / 1 \mathrm{lt}$ & 17.0 & 12.0 \\
\hline MNCN 74604 & $\mathrm{~m} / 3 \mathrm{rt}$ & 34.0 & 18.7 \\
\hline MNCN 74604 & $\mathrm{~m} / 3 \mathrm{lt}$ & 35.1 & 21.2 \\
\hline MNCN 74605 & $\mathrm{M} 1 / \mathrm{rt}$ & 17.2 & 15.6 \\
\hline
\end{tabular}

the teeth lying almost in the same plane in an almost flat symphysis. The rami have been crushed together and twisted with respect to the symphyseal part of the jaw but it is possible to see that the $i / 3$ alveolus is stepped back from the $\mathrm{i} / 2$ alveolus, and is immediately followed by the canine. Thus the canine is in a very anterior position.

Barajas yielded a left IVth metacarpal (MNCN 74610) which can be attributed to Listriodon retamaensis on the basis of its dimensions (Fig. 35). The bone is relatively short within a listriodont context, with a flat axial surface indicating that the MC III was positioned close to it throughout its length, presumably adaptations for cursorial behaviour. The distal epiphysis is broad with a prominent central ridge that extends right to the anterior part of the epiphysis on its dorsal and palmar sides.

Guadarrama I. The mandible from Guadarrama I, near Bohadilla del Monte (MNCN 72851) is crushed and the teeth are compressed, so that accurate measurements are not easy to obtain (Fig. 36). The jaw is shallow, as is the case in Listriodon in general. It is possible to estimate the dimensions of the $\mathrm{p} / 4-\mathrm{m} / 3$ in the jaw, which are comparable in morphology to specimens from Mahou, and we have little hesitation in attributing this specimen to Listriodon retamaensis. The $\mathrm{p} / 4$ and $\mathrm{m} / 1$ are poorly preserved and the $\mathrm{m} / 2$ is moderately worn. The $\mathrm{m} / 3$ in contrast is unworn and shows the bunodont cusp morphology well. The anterior accessory cusplet is small as is usual in Listriodon and is closely applied to the protoconid. The median accessory cusplet is large, but the posterior one is reduced in dimensions. The talonid is simple with no sign of a posterior accessory cusplet.

Table 6. Measurements (in $\mathrm{mm}$ ) of the teeth of Listriodon retamaensis from Guadarrama I, near Bohadilla del Monte, Madrid (Spain). 1t: left; rt: right; --: no measurement possible; e: estimated measurement.

\begin{tabular}{lccc}
\hline Catalogue & Tooth & $\begin{array}{c}\text { Mesio-distal } \\
\text { Length }\end{array}$ & $\begin{array}{c}\text { Bucco-lingual } \\
\text { Breadth }\end{array}$ \\
\hline MNCN 72851 & $\mathrm{p} / 4 \mathrm{rt}$ & $13.9 \mathrm{e}$ & $11.6 \mathrm{e}$ \\
MNCN 72851 & $\mathrm{m} / 1 \mathrm{rt}$ & $18.0 \mathrm{e}$ & $15.4 \mathrm{e}$ \\
MNCN 72851 & $\mathrm{m} / 2 \mathrm{rt}$ & 21.5 & 16.5 \\
MNCN 72851 & $\mathrm{m} / 3 \mathrm{rt}$ & 32.0 & -- \\
\hline
\end{tabular}

Subfamily Tetraconodontine Lydekker, 1876

Genus Retroporcus Pickford \& Laurent, 2014

Species Retroporcus complutensis Pickford \& Laurent, 2014

Holotype. MNCN SOM N Cata 2 2008-83, left mandible containing $\mathrm{p} / 2-\mathrm{m} / 3$ from Somosaguas, Spain.

Material. MNCN NG 1012, left I1/, MNCN NG 1011, right $\mathrm{d} / 4$, from Los Nogales, Spain. 

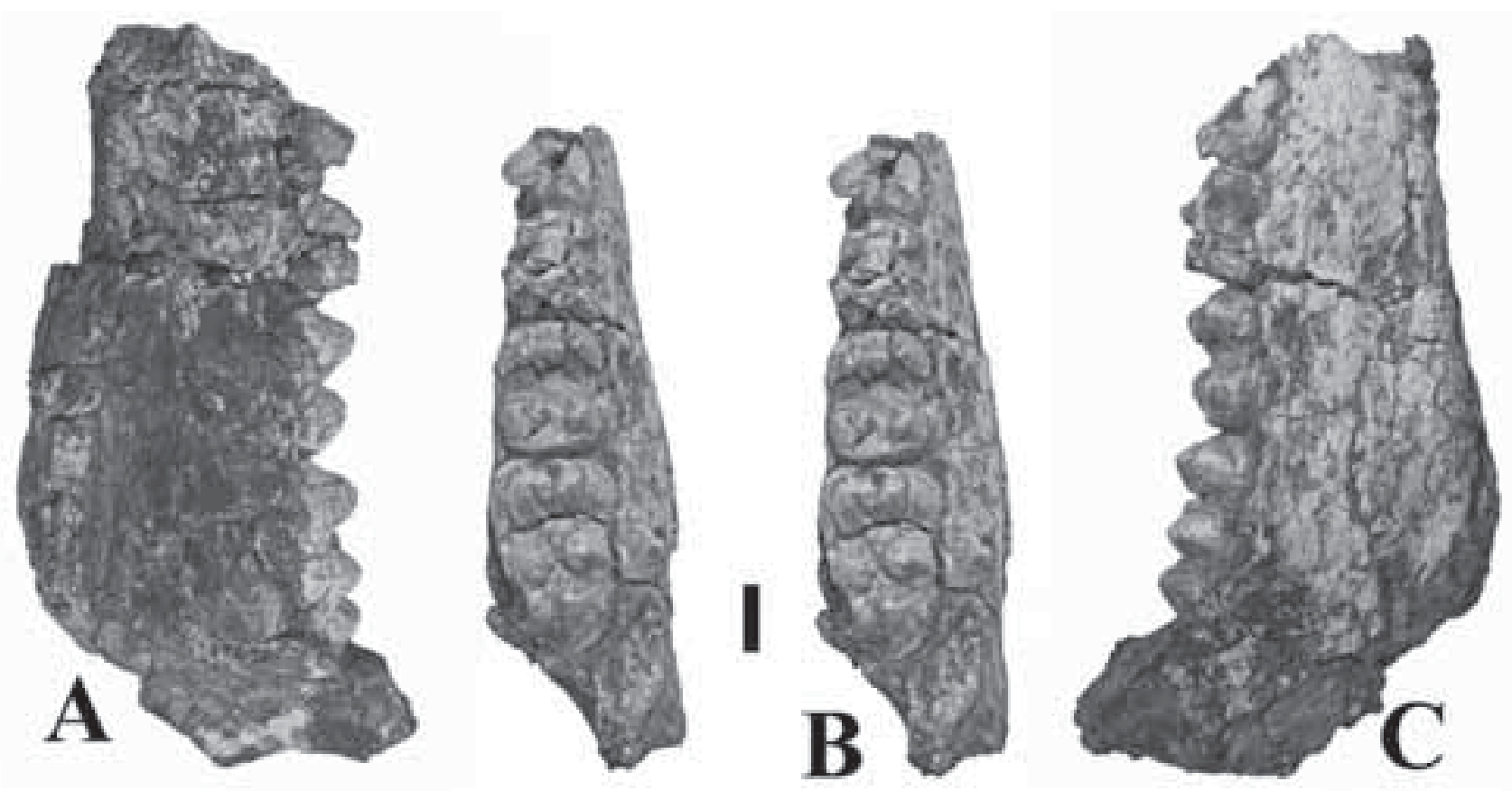

Figure 36. Listriodon retamaensis from Guadarrama I (Spain). MNCN 72851, right mandible containing damaged p/4-m/3 in lingual (A), stereo occlusal (B), and buccal (C) views. Scale bar $=10 \mathrm{~mm}$.

Description. There are two teeth from Los Nogales (left I1/ and right D4/) (Figs 23b-23c. Table 7) that agree in morphology and dimensions with the small tetraconodont suid Retroporcus complutensis defined on the basis of fossils from Somosaguas (Pickford \& Laurent, 2014). They are included here in order to complete the suid fauna from the site. The I1/ has a distal cusp on the buccal side, and the D4/ has bunodont main cusps with almost circular enamel outlines as is usual in tetraconodonts.

Table 7. Measurements (in $\mathrm{mm}$ ) of the teeth of Retroporcus complutensis from Los Nogales, Madrid (Spain). 1t: left; rt: right.

\begin{tabular}{lccc}
\hline Catalogue & Tooth & $\begin{array}{c}\text { Mesio-distal } \\
\text { Length }\end{array}$ & $\begin{array}{c}\text { Bucco-lingual } \\
\text { Breadth }\end{array}$ \\
\hline MNCN NG 1011 & D4/ rt & 11.8 & 11.5 \\
MNCN NG 1012 & I1/ lt & 10.2 & 7.4 \\
\hline
\end{tabular}

Metric analysis of Spanish listriodont dentitions. The dental remains from Mahou, La Hidroeléctrica, Los Nogales, Guadarrama I, and Barajas are small within the context of European Listriodontinae, and accord well with the species Listriodon retamaensis.

In their paper on Listriodon retamaensis, Pickford \& Morales (2003) included several samples from other sites in Spain and Portugal which were generally smaller than Listriodon latidens, and which had been classified by Van der Made (1996) as Bunolistriodon aff. latidens. The augmented samples of Listriodon retamaensis from Mahou and other sites in Madrid, permit a test of this hypothesis, which reveals that material from Casal das Chitas, Quinta Conceicao, Quinta das Flamengas, Quinta Grande, Quinta da Raposa and Olival da Susana is consistently larger than the combined Retama and Mahou samples. This indicates that the Portuguese fossils probably represent a different species. The same applies to fossils from Munebrega, Valdemoros and Torralba in Spain.

Other specimens from Portugal and Spain transferred to Listriodon retamaensis by Pickford \& Morales (2003) are compatible in dimensions with the augmented Madrid sample of the species, which suggests that this taxon does occur in the Tagus deposits and elsewhere in Spain. It is possible that the size differences noted could be of stratigraphic importance. The Tagus sites at which the smaller specimens occur are Quinta da Farinheira, Courelas do Cavao, Quinta da Silveria and Quinta da Lobeira.

\section{DISCUSSION}

Among all the described listriodont species, the Mahou and other Madrid samples described herein are closest in morphology and dimensions to Listriodon retamaensis from Retama (Fig. 40) and other Spanish localities (Fig. 40) (see list in Pickford \& Morales, 2003). Orliac (2006) 


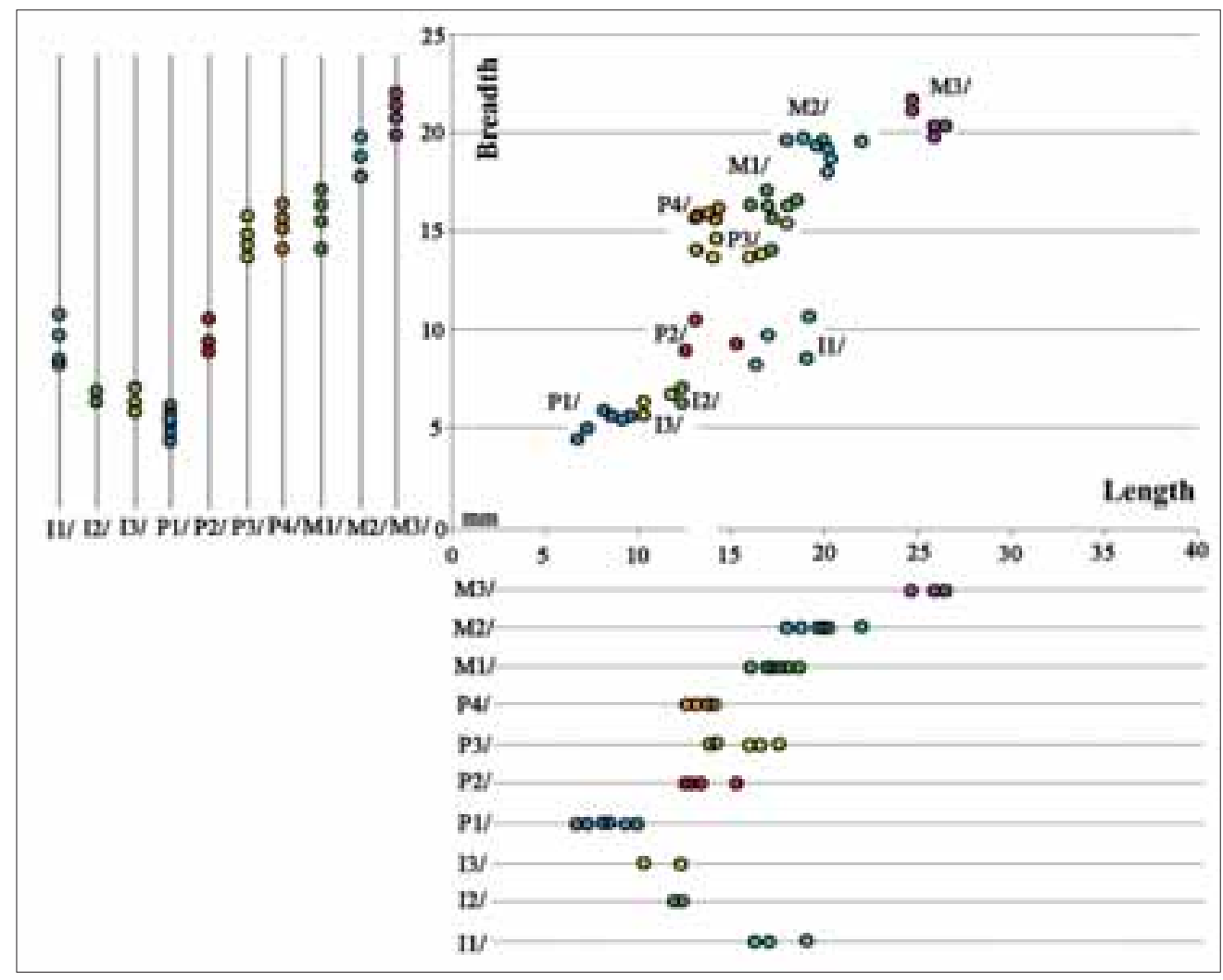

Figure 37. B ivariate and univariate plots of the upper teeth of Listriodon retamaensis from Mahou and material from other localities in the Spanish Peninsula.

disagreed with the attribution by Pickford \& Morales (2003) of the fossils from Bézian, France, to this species and this seems to be a correct challenge, as those specimens are morphometrically closer to Listriodon lockharti. This means that the known fossil record of Listriodon retamaensis is confined to the Spanish Peninsula, although there is an unworn lower third molar from Turkey (MM LL 115) (Fig. 41), which is remarkably similar to the Mahou fossils. This specimen is from Erenköy in the vicinity of the Sea of Marmara. It was collected by Frank Calvert in the 1800's (Calvert \& Neumayr, 1880) and is curated at the Manchester Museum under the spelling Renkioi (Fig. 41). Calvert \& Neumayr (1880) attributed this specimen to Sus erymanthius (archives in the Manchester Museum) but its dimensions (33.8 x $18.1 \mathrm{~mm})$ and its morphology indicate that it belongs to a bunodont listriodont. These authors also listed Listriodon splendens at the site. The latter record is based on an upper central incisor fragment (MM LL 15691), which is most similar to specimens from Çandir (Turkey) attributed to Listriodon meidamon. There is thus a potential link between the Spanish species Listriodon retamaensis and the Turkish one Listriodon meidamon (Fortelius et al., 1996).

In addition, the Retama species appears to be related to the sub-lophodont taxon Listriodon guptai from Bugti and Sind (Pakistan) (Pilgrim, 1926; Orliac et al., 2009), and thence to the fully lophodont taxon Listriodon pentapotamiae of the Indian Subcontinent (Pickford, 1988). The main differences between Listriodon retamaensis and Listriodon guptai concern the slightly better development of lophodonty in the Pakistan species, and the more hook-shaped upper central incisor when viewed from the lingual aspect. Apart from these relatively minor differences which plead for a younger age for the Bugti and Sind specimens than those from Retama and Mahou (MN 4a), the two taxa are evidently related to one another, and indicate the probability of dispersal between the two regions at the beginning of the middle Miocene.

This raises an important point, in that the Mahou fossils possess several characters that are shared with Hyotherium major from older European deposits (MN 2) including the presence of buccal cingula on the upper molars, a lingually positioned talon in $\mathrm{M} 3 /$, and similar crown morphology in the $\mathrm{P} 1 /$. Thus, it is possible that Listriodon descended from an early species of Hyotherium, the main cranio-dental changes being the development of hypselodont canines (in males), which flare outwards much more than the almost vertically implanted canines in Hyotherium, development of diastemata between the $\mathrm{P} 1 /$ and $\mathrm{P} 2 /$ (and $\mathrm{p} / 1$ and $\mathrm{p} / 2$ ), and a tendency to reduce the dimensions of $\mathrm{P} 1 /$ and $\mathrm{p} / 1$, eventually to be suppressed altogether in later species of Listriodon. The lineage also increased in body size. This suggests that, contrary to the long established scenario that this genus dispersed to Europe from Asia (for discussion see Ginsburg, 1974) Listriodon probably evolved in Europe (in particular in the Spanish Peninsula) and then spread to the rest of Eurasia and Africa. 


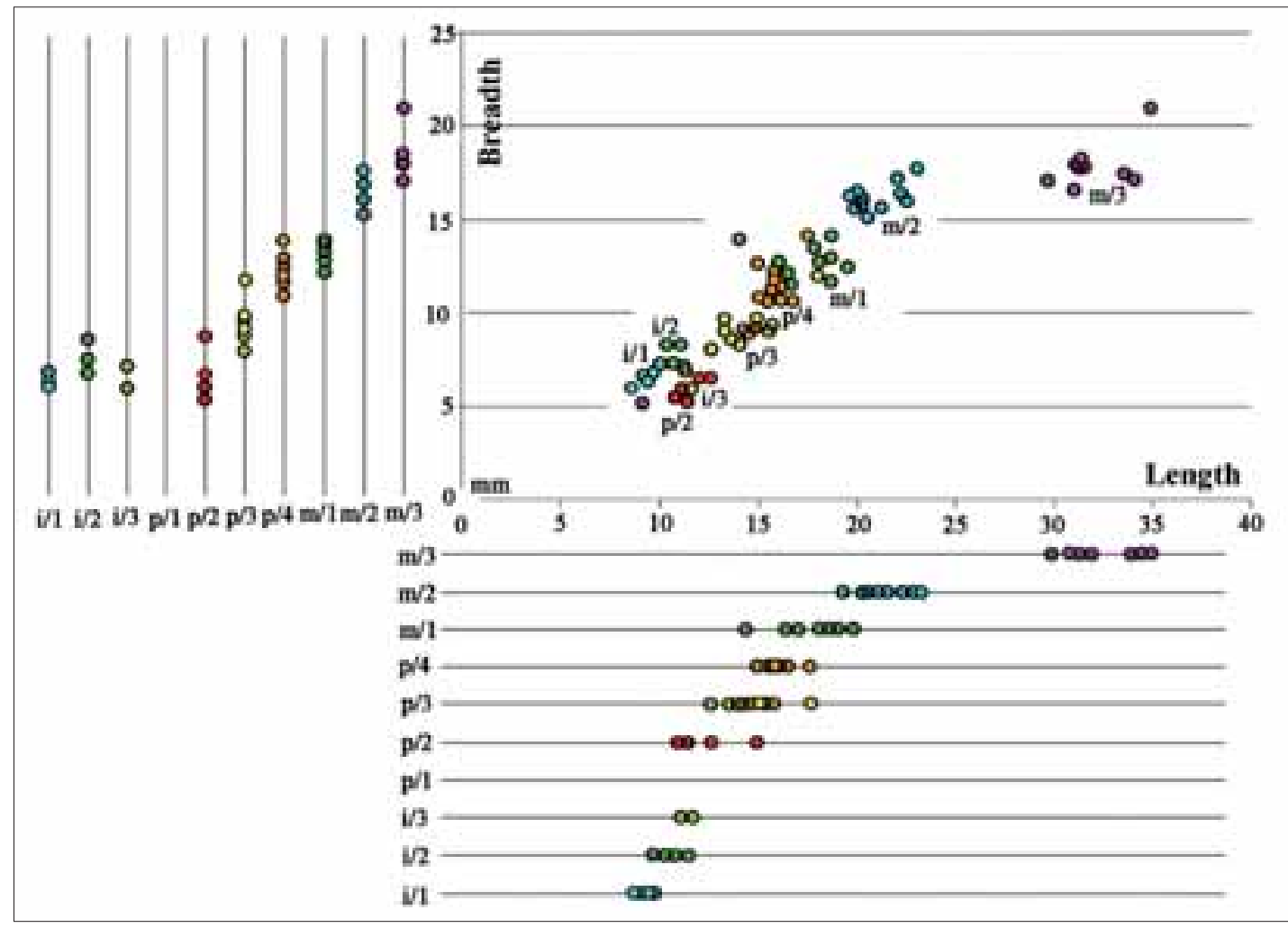

Figure 38. Bivariate and univariate plots of the lower teeth of Listriodon retamaensis from Mahou and material from other localities in the Spanish Peninsula.

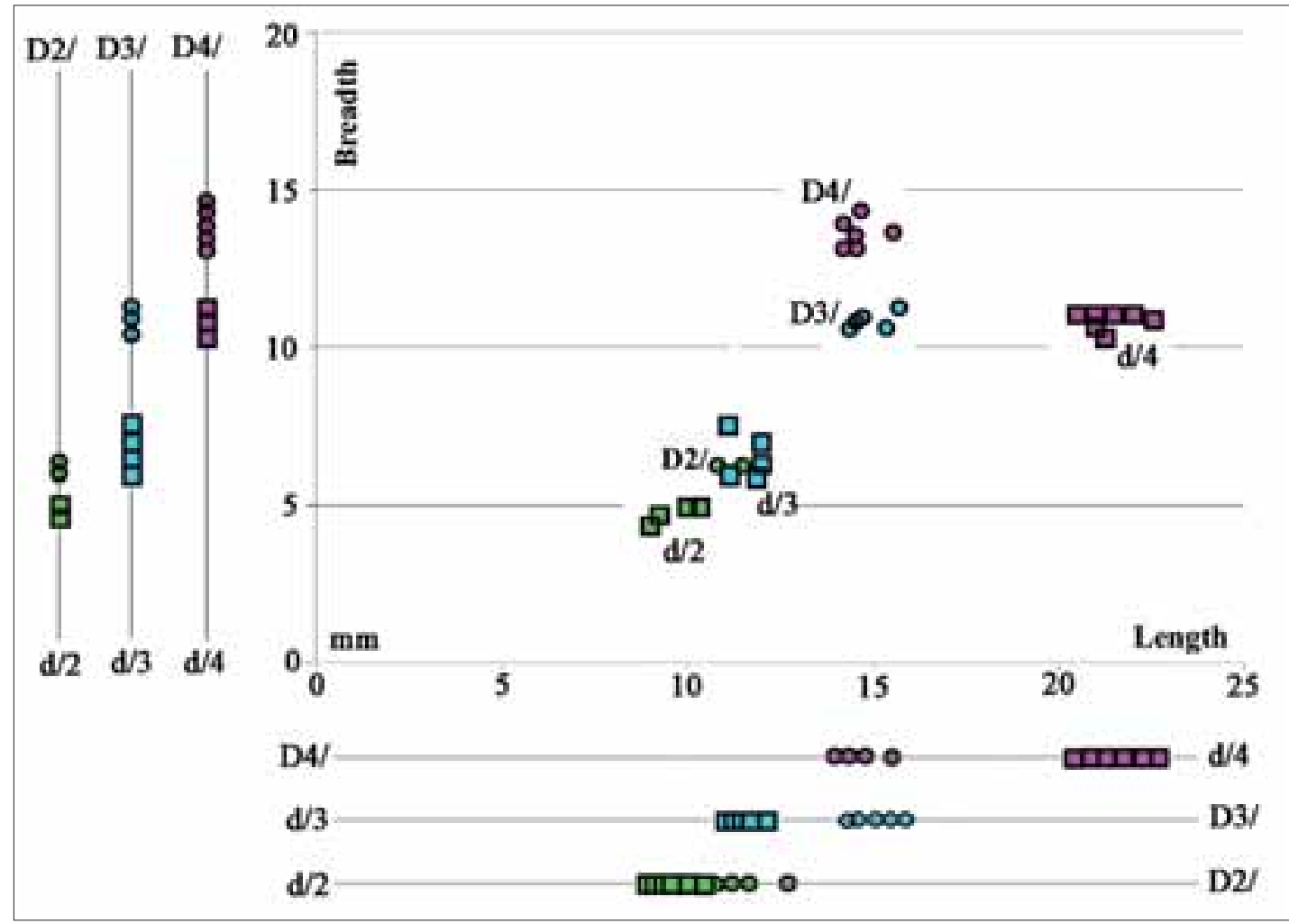

Figure 39. Bivariate and univariate plots of the deciduous teeth of Listriodon retamaensis from Mahou and material from other localities in the Spanish Peninsula. 
In the Retama listriodont sample, which comprises the type and paratypes of Listriodon retamaensis, the cheek teeth and incisors are all rather heavily worn, meaning that the detailed structure of the cusps and grooves could not be determined. In contrast, the Mahou listriodont sample described here comprises principally juvenile and subadult individuals, although there is a mandible of a senile male individual in the collection. As such, fine details of the crown morphology are preserved in several specimens, and it has thus been possible to describe in detail the cusp and furrow morphology of most of the permanent teeth. The outcome is that the species can be described as being bunolophodont, but more lophodont than Listriodon lockharti and Eurolistriodon tenarezensis.

The upper incisor from Mahou is of the three-lobed kind (Fig. 42), as in Listriodon guptai, Listriodon pentapotamiae, Listriodon latidens, and Listriodon meidamon and to some extent Listriodon lockharti (Fig. 42). There can be little doubt that these species plus Listriodon retamaensis comprise a lineage distinct from Eurolistriodon adelli on the one hand, and the Listriodon lockharti + Listriodon splendens group on the other. Listriodon retamaensis and Listriodon lockharti share the presence of a concave profile in the distal lobe of the I1/, which is slightly convex in Listriodon latidens, Listriodon meidamon and Listriodon splendens. Eurolistriodon tenarezensis occupies an ambiguous position because it shares some features with Listriodon retamaensis, notably the upper central incisor morphology and the presence of first and second premolars in the upper and lower tooth rows, but it differs from this species by its greater dimensions, in particular of the premolars, and by the incomplete buccal cingulum on the upper molars. On the other hand, Eurolistriodon tenarezensis differs from Eurolistriodon adelli, the type species of the genus (Pickford \& Moyà-Solà, 1995), which has lost the first two premolars in the upper tooth row and the $\mathrm{p} / 2$ from the lower tooth row, but which has fully developed buccal cingula in the upper molars, well-formed anterior, median and posterior accessory cusplets in the molars, a single lobed upper central incisor and a weakly expressed Innenhügel in the $\mathrm{p} / 4$. E. tenarezensis resembles $E$. adelli in possessing a single cusp on the buccal side of the $\mathrm{P} 4 /$ and by the presence of large laterally flaring canine flanges in males from the ventral surface of which

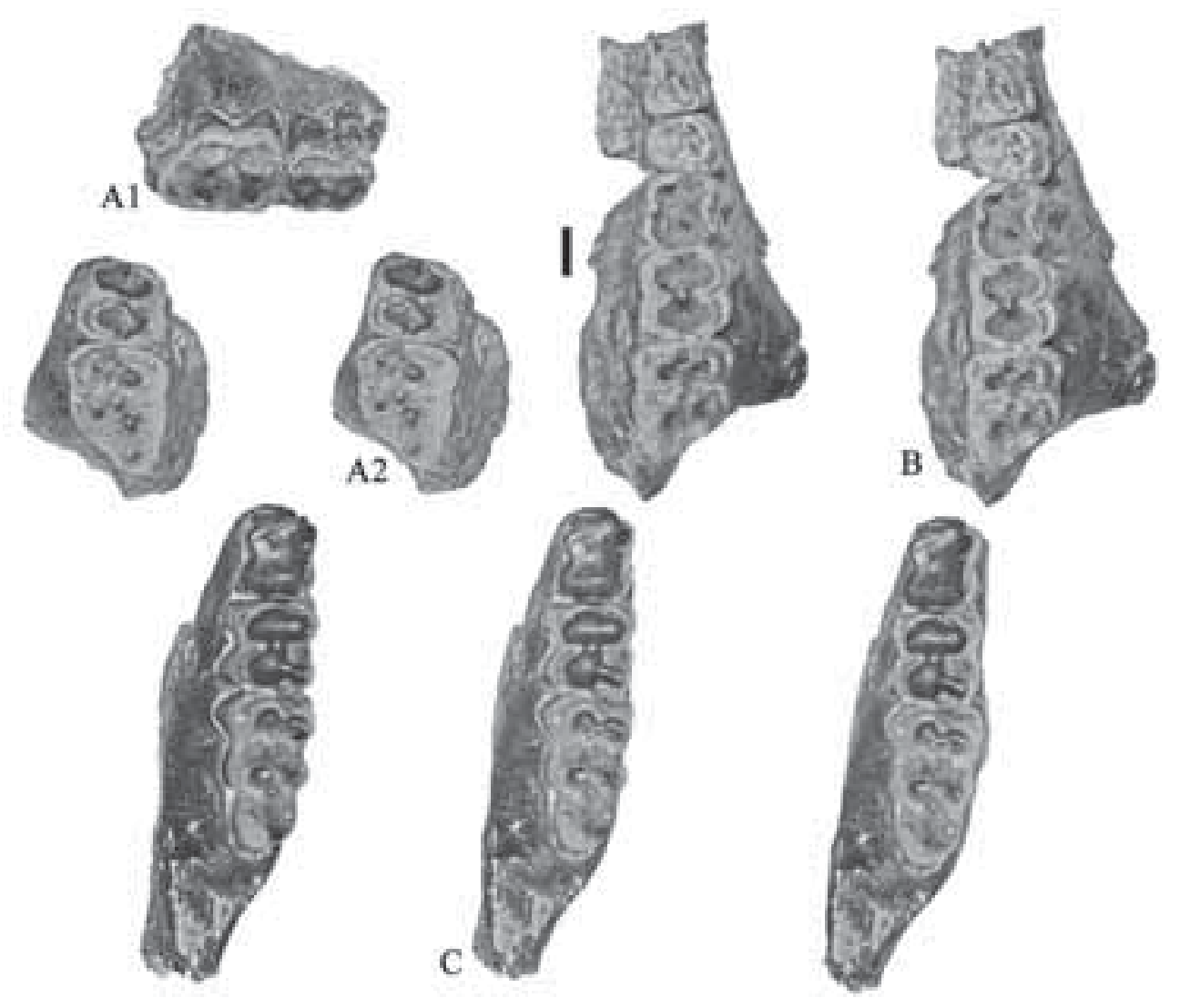

Figure 40. Listriodon retamaensis from Retama, Huete (Spain). a) MNCN RET 348 right maxilla containing M2/-M3/ in oblique buccal view (A1) to show the prominent buccal cingulum, and stereo occlusal view (A2). b) MNCN RET 348, left maxilla containing P3/-M3/, stereo occlusal view. c) MNCN RET 2, left mandible containing worn $\mathrm{m} / 1-\mathrm{m} / 3$, stereo triplet of occlusal view. Scale bar $=10 \mathrm{~mm}$. 


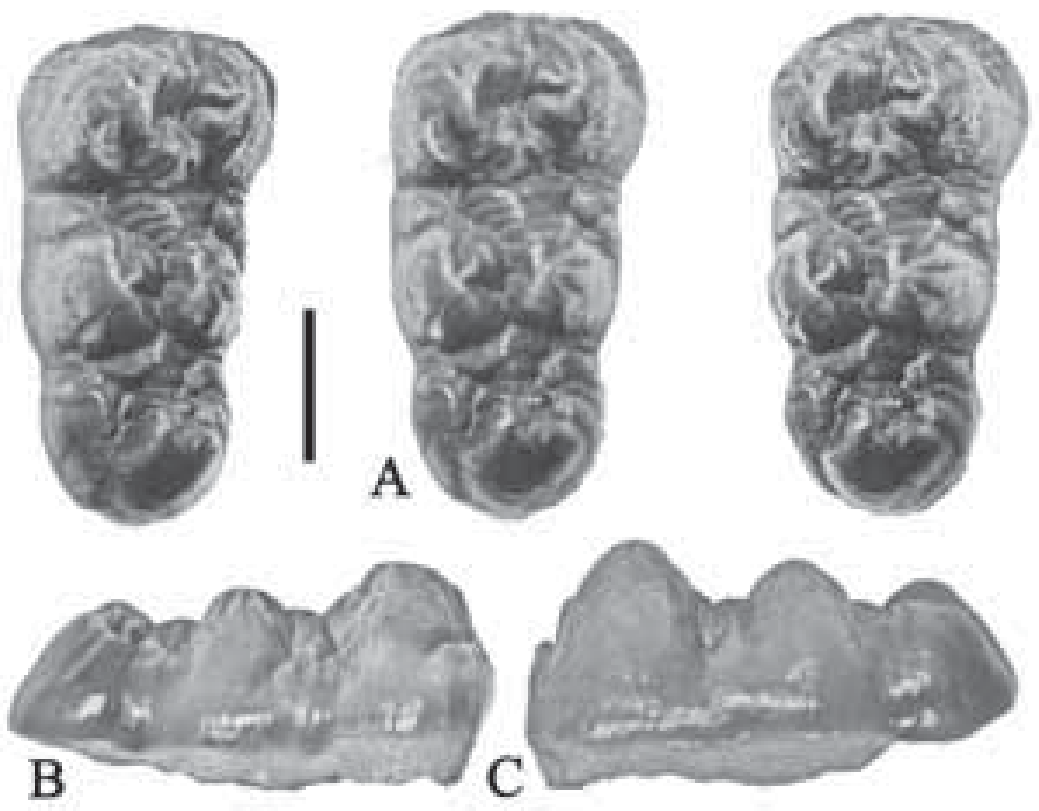

Figure 41. MM LL 115, right $\mathrm{m} / 3$ from Erenköy, Turkey, housed in the Manchester Museum. Stereo occlusal triplet (A), buccal (B), and lingual $(\mathrm{C})$ views. Scale bar $=10 \mathrm{~mm}$.
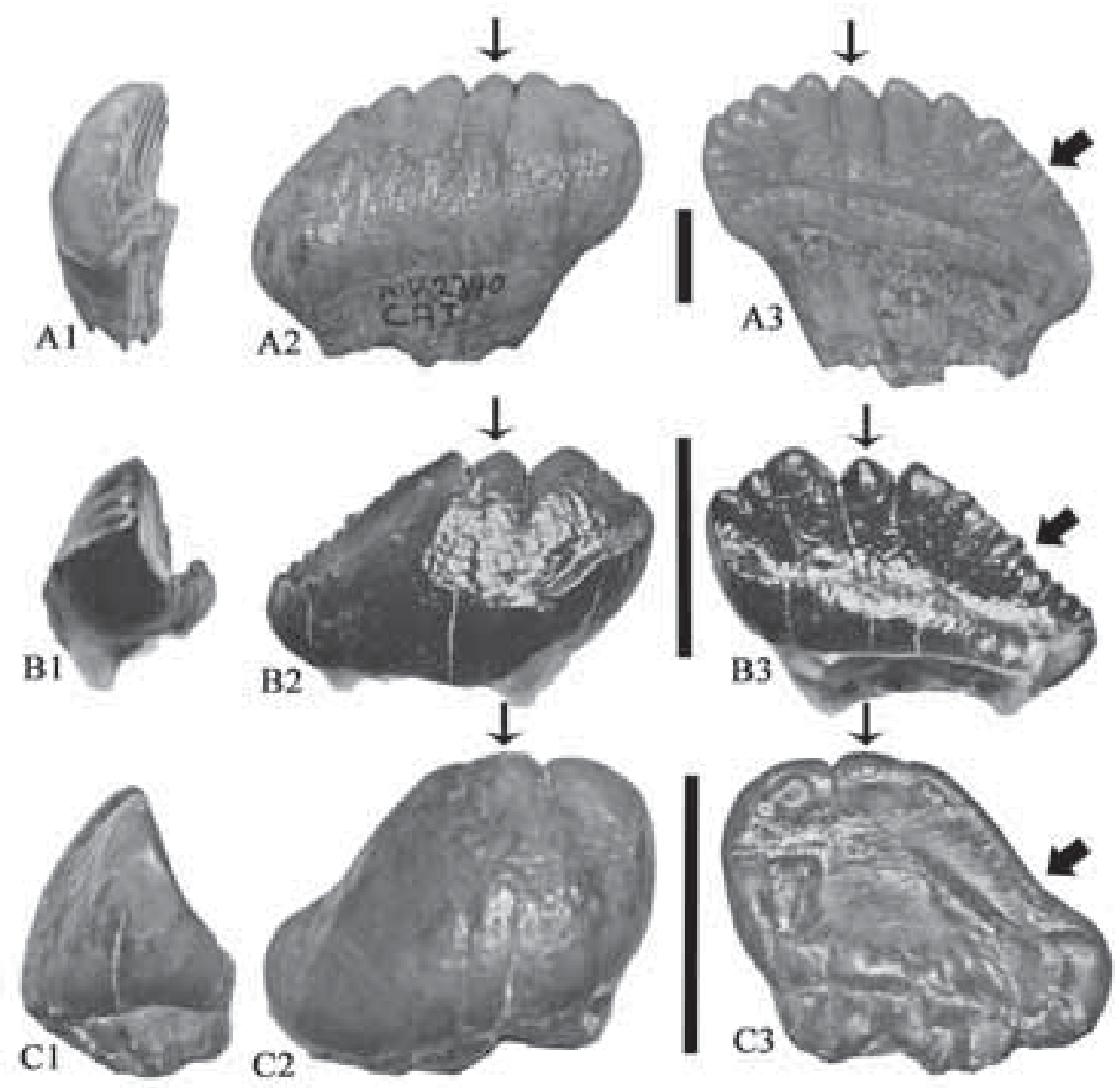

Figure 42. Comparison of left I1/s of Listriodon meidamon from Çandir (Turkey) (PIMUZ A/V 2340) (a) with Listriodon retamaensis from Mahou (Spain) (MNCN FMH'14 3623) (b), and Listriodon lockharti from Benken (Switzerland) (PIMUZ A/V 4921) (c). The images are brought to the same size for ease of comparison. (A1-C1) mesial, (A2-C2) labial, and (C3-C3) lingual views. Small arrows show middle lobe. Large arrows show profile in the apical edge of the crown, which is concave in some taxa, straight or convex in others. Scale bars $=10 \mathrm{~mm}$. 
the canines emerge (Pickford \& Moyà-Solà, 1995; Orliac, 2006). What all this suggests is that Western Europe was a zone of active evolution among early Listriodontinae with a variety of selective pressures at play, resulting in local and regional adaptations which translated into a high diversity of forms at the scale of the continent.

In this context, it is interesting to note that the juvenile snout of Listriodon retamaensis from Mahou shows a significant development of the canine jugum extending laterally from the palate, containing a laterally flaring canine. The canine jugum is as broad medio-laterally as is the palate measured from its midline to the outer margin of the palatine groove. The flange thus doubles the breadth of the snout at the level of the canines, just as in Eurolistriodon adelli and Eurolistriodon tenarezensis. However, the canine jugum is incompletely formed due to the juvenile status of the individual, and it is not possible to determine whether it would mature into the Eurolistriodon kind or the Listriodon kind. As preserved, the canine appears to be emerging from the end of the jugum, which would support affinities with Listriodon, but the bone is damaged in this zone, so that it cannot be ruled out that it was erupting from the ventral surface of the jugum, in which case it would indicate a closer relationship with Eurolistriodon.

The metric similarities between the dental samples from Retama and Mahou suggest that the two localities are close in age $(\mathrm{MN} \mathrm{4a})$.

\section{ACKNOWLEDGEMENTS}

We thank Enrique Cantero for preparing and restoring the fossils, and Susana Fraile and Patricia Pérez-Dios curators at the Museo Nacional de Ciencias Naturales. María Dolores Pesquero and Adrián de la Iglesia excavated the site at Mahou. Support from the Dirección General de Patrimonio (Autonomous Community of Madrid) Project CGL2015-68333-P (MINECO/FEDER, UE) and the Research Group BSCH-UCM 910607 is gratefully acknowledged. Thanks to Sevket Sen for alerting us to the presence of fossil mammals from Turkey in the Manchester Museum, and to Rachel Petts (Manchester) for providing access to the fossils. Comments by the two referees helped to improve the presentation of the paper.

\section{REFERENCES}

Bruijn, H. de, Daams, R., Daxner-Höck, G., Fahlbusch, V., Ginsburg, L., Mein, P. \& Morales, J. 1992. Report of the RCMNS working group on fossil mammals,
Reisensberg 1990. Newsletters on Stratigraphy, 26, 65118; doi:10.1127/nos/26/1992/65.

Calvert, F. \& Neumayr, M. 1880. Die Jungen Ablagerungen am Hellespont. Denkschriften der Kaiserlichen Akademie der Wissenschaften / Mathematisch-Naturwissenschaftliche Klasse, 40, 357-378.

Calvo, J.P., Daams, R., Morales, J., López-Martínez, N., Agustí, J., Anadón, P., Armenteros, I., Cabrera, L., Civis, J., Corrochano, A., Díaz-Molina, M., Elizaga, E., Hoyos, M., Martín-Suárez, E., Martínez, J., Moissenet, E., Muñoz, A., Pérez-García, A., Pérez-González, A., Portero, J.M., Robles, F., Santisteban, C., Torres, T., Van der Meulen, A.J., Vera, J.A. \& Mein, P. 1993. Up-to-date Spanish continental Neogene synthesis and Paleoclimatic interpretation. Revista de la Sociedad Geológica de España, 6, 29-40.

Daams, R., Van der Meulen, A.J., Álvarez Sierra, M.A., Peláez-Campomanes, P., Calvo, J.P., Alonso Zarza, M.A. \& Krijgsman, W. 1999. Stratigraphy and sedimentology of the Aragonian (Early to Middle Miocene) in its type area North-Central Spain. Newsletters on Stratigraphy, 37, 103-139; doi: 10.1127/nos/37/1999/103.

Fortelius, M., Van der Made, J. \& Bernor, R. 1996. A new listriodont suid, Bunolistriodon meidamon sp. nov., from the Middle Miocene of Anatolia. Journal of Vertebrate Paleontology, 16, 149-164; doi: 10.1080/02724634.1996.10011293.

Ginsburg, L. 1974. Les Tayassuides des Phosphorites du Quercy. Palaeovertebrata, 6, 55-85.

Gray, J.E. 1821. On the natural arrangement of vertebrose animals. London Medical Repository, 15, 296-310.

Hernández-Pacheco, E. 1921. Nuevos yacimientos de vertebrados miocenos y deducciones de orden paleofisiográfico. Asociación Española para el Progreso de las Ciencias. Congreso de Oporto, 6, 159-170.

Herráez, E., García-Paredes, I., Peláez-Campomanes, P. \& Morales, J. 2006. Los Nogales, nueva fauna de vertebrados del Mioceno medio de Madrid. Estudios Geológicos, 62, 257-262; doi: 10/3989/egeol.0662125.

Hünermann, K.A. 1968. Die Suidae (Mammalia, Artiodactyla) aus den Dinotheriensanden $($ Unter pliozän $=$ Pont $)$ Rheinhessens (Südwestdeutschland). Schweizerische Paläontologische Abhandlungen, 86, 1-96.

Leinders, J.J.M. 1976. Some aspects of the ankle joint of artiodactyls with special reference to Listriodon (Suina). Proceedings of the Koninklijke Nederlandse Akademie van Wetenschappen, B79, 45-54.

López-Martínez, N., Sesé, C. \& Herráez, E. 1987. Los yacimientos de Micromamíferos del área de Madrid. Boletín Geológico y Minero, 98, 159-176.

Lydekker, R. 1876. Fossil mammalian faunae of India and Burma. Records of the Geological Survey of India, 9, 86-106.

Mein, P. 1975. Biozonation du Néogène Mediterranéen à partir des Mammifères. VIth Congress of the R.C.M.N.S., Bratislava, Slowakia.

Morales, J., Nieto, M., Amezua, L., Fraile, S., Gómez, E., Herráez, E., Peláez-Campomanes, P., Salesa, M.J., 
Sánchez, I.M. \& Soria, D. (eds) 2000. Patrimonio Paleontológico de la Comunidad de Madrid. Serie Arqueología, Paleontología y Etnografía, 6. Comunidad de Madrid

Orliac, M.J. 2006. Eurolistriodon tenarezensis sp. nov., from Montréal du-Gers (France): implications for the systematics of the European Listriodontinae (Suidae, Mammalia). Journal of Vertebrate Paleontology, 26, 967-980; doi: 10.1671/0272-4634(2006)26[967:ETSNF $\mathrm{M}] 2.0 . \mathrm{CO} ; 2$.

Orliac, M.J., Antoine, P.-A., Métais, G., Marivaux, L., Crochet, J.-Y., Welcomme, J.-L., Baqri, S.R.H. \& Roohi, G. 2009. Listriodon guptai Pilgrim, 1926 (Mammalia, Suidae) from the early Miocene of the Bugti Hills, Balochistan, Pakistan: new insights into early Listriodontinae evolution and biogeography. Naturwissenschaften, 96, 911-920; doi: 10.1007/s00114-009-0547-4.

Osborn, H.F. 1907. Evolution of Mammalian Molar Teeth to and from the Triangular Type Including Collected and Revised Researches on Trituberculy and New Sections on the Forms and Homologies of the Molar Teeth in the Different Orders of Mammals. New York, MacMillan, $250 \mathrm{pp}$.

Peláez-Campomane, P., Morales, J., Álvarez Sierra, M.A., Azanza, B., Fraile, S., García Paredes, I., Hernández Fernández, M., Herráez, E., Nieto, M., Pérez, B., Quiralte, V., Salesa, M.J., Sánchez, I.M. \& Soria, D. 2003. Updated biochronology of the Miocene mammal faunas from the Madrid basin (Spain). In: Distribution and Migration of Tertiary Mammals in Eurasia. A Volume in Honour of Hans de Bruijn (eds Reumer, J.W.F. \& Wessels, W. ). Deinsea, 10, 431-441
Pickford, M. 1988. Revision of the Miocene Suidae of the Indian Subcontinent. Münchner Geowissenschaftliche Abhandlungen, 12, 1-91.

Pickford, M. \& Laurent, Y. 2014. Valorisation of palaeontological collections: nomination of a lectotype for Conohyus simorrensis (Lartet, 1851), Villefranche d'Astarac, France, and description of a new genus of tetraconodont. Estudios Geológicos, 70, e002. doi: 10.3989/egeol.41261.262.

Pickford, M. \& Morales, J. 2003. New Listriodontinae (Suidae, Mammalia) from Europe and a review of listriodont evolution, biostratigraphy and biogeography. Geodiversitas, 25, 1-58.

Pickford, M. \& Moyà-Solà, S. 1995. Eurolistriodon gen. nov. (Suoidea, Mammalia) from Els Casots, early middle Miocene, Spain. Proceedings of the Koninklijke Nederlandse Akademie van Wetenschappen, 98, 343-360.

Pilgrim, G.E. 1926. The Fossil Suidae of India. Memoir of the Geological Survey of India, Palaeontologica Indica, 8, 1-65.

Simpson, G.G. 1945. The principals of classification and a classification of mammals. Bulletin of the American Museum of Natural History, 85, 1-350.

Van der Made, J. 1996. Listriodontinae (Suidae, Mammalia): their evolution, systematics and distribution in time and space. Contributions to Tertiary and Quaternary Geology, 33, 3-254.

Von Meyer, H. 1846. Mitteilungen an Prof. Bronn gerichtet. Neues Jahrbuch für Mineralogie, Geologie und Paläontologie, 1846, 462-476. 
